University of Nebraska - Lincoln

DigitalCommons@University of Nebraska - Lincoln

2010

\title{
Microbial and Mineralogical Characterizations of Soils Collected from the Deep Biosphere of the Former Homestake Gold Mine, South Dakota
}

\author{
Gurdeep Rastogi \\ South Dakota School of Mines and Technology \\ Shariff Osman \\ Lawrence Berkeley National Laboratory \\ Ravi K. Kukkadapu \\ Pacific Northwest National Laboratory, ravi.kukkadapu@pnl.gov \\ Mark Engelhard \\ Pacific Northwest National Laboratory \\ Parag A. Vaishampayan \\ California Institute of Technology \\ See next page for additional authors \\ Follow this and additional works at: https://digitalcommons.unl.edu/usdoepub \\ Part of the Bioresource and Agricultural Engineering Commons
}

Rastogi, Gurdeep; Osman, Shariff; Kukkadapu, Ravi K.; Engelhard, Mark; Vaishampayan, Parag A.; Andersen, Gary L.; and Sani, Rajesh K., "Microbial and Mineralogical Characterizations of Soils Collected from the Deep Biosphere of the Former Homestake Gold Mine, South Dakota" (2010). US Department of Energy Publications. 170.

https://digitalcommons.unl.edu/usdoepub/170

This Article is brought to you for free and open access by the U.S. Department of Energy at DigitalCommons@University of Nebraska - Lincoln. It has been accepted for inclusion in US Department of Energy Publications by an authorized administrator of DigitalCommons@University of Nebraska - Lincoln. 


\section{Authors}

Gurdeep Rastogi, Shariff Osman, Ravi K. Kukkadapu, Mark Engelhard, Parag A. Vaishampayan, Gary L. Andersen, and Rajesh K. Sani 


\title{
Microbial and Mineralogical Characterizations of Soils Collected from the Deep Biosphere of the Former Homestake Gold Mine, South Dakota
}

\author{
Gurdeep Rastogi • Shariff Osman • Ravi Kukkadapu • \\ Mark Engelhard • Parag A. Vaishampayan • \\ Gary L. Andersen • Rajesh K. Sani
}

Received: 3 January 2010 / Accepted: 13 March 2010 /Published online: 13 April 2010

(C) Springer Science+Business Media, LLC 2010

\begin{abstract}
A microbial census on deep biosphere (1.34 km depth) microbial communities was performed in two soil samples collected from the Ross and number 6 Winze sites of the former Homestake gold mine, Lead, South Dakota using high-density 16S microarrays (PhyloChip). Soil mineralogical characterization was carried out using X-ray diffraction, X-ray photoelectron, and Mössbauer spectroscopic techniques which demonstrated silicates and iron minerals (phyllosilicates and clays) in both samples. Microarray data revealed extensive bacterial diversity in soils and detected the largest
\end{abstract}

Electronic supplementary material The online version of this article (doi:10.1007/s00248-010-9657-y) contains supplementary material, which is available to authorized users.

G. Rastogi $\cdot$ R. K. Sani $(\bowtie)$

Department of Chemical and Biological Engineering,

South Dakota School of Mines and Technology,

Rapid City, SD 57701, USA

e-mail: Rajesh.Sani@sdsmt.edu

S. Osman · G. L. Andersen

Ecology Department, Earth Sciences Division,

Lawrence Berkeley National Laboratory,

Berkeley, CA 94720, USA

R. Kukkadapu $\cdot$ M. Engelhard

WR Wiley Environmental Molecular Sciences Laboratory,

Pacific Northwest National Laboratory,

Richland, WA 99352, USA

P. A. Vaishampayan

California Institute of Technology, Jet Propulsion Laboratory,

Pasadena, CA 91109, USA

Present Address:

G. Rastogi

Department of Plant Pathology, University of California,

Davis 95616, USA number of taxa in Proteobacteria phylum followed by Firmicutes and Actinobacteria. The archael communities in the deep gold mine environments were less diverse and belonged to phyla Euryarchaeota and Crenarchaeota. Both the samples showed remarkable similarities in microbial communities (1,360 common OTUs) despite distinct geochemical characteristics. Fifty-seven phylotypes could not be classified even at phylum level representing a hitherto unidentified diversity in deep biosphere. PhyloChip data also suggested considerable metabolic diversity by capturing several physiological groups such as sulfur-oxidizer, ammonia-oxidizers, iron-oxidizers, methane-oxidizers, and sulfate-reducers in both samples. High-density microarrays revealed the greatest prokaryotic diversity ever reported from deep subsurface habitat of gold mines.

\section{Introduction}

Ultra-deep mines provides a unique access to examine the microbial communities in deep terrestrial subsurface environments where hostile life conditions such as extreme temperature, $\mathrm{pH}$, pressure, low oxygen concentration, no light and toxic metals persist. Several investigations, both culture-based and culture-independent, on gold mines in Japan [13, 14, 23], South Africa [3, 7, 12, 16, 21, 25, 38], Canada [24], and the USA [27, 30] have demonstrated active diverse microbial populations with bewildering metabolic capabilities. These studies also shed light on the spectacular biogeochemistry that governs microbial community composition in deep biosphere where contemporary photosynthetically derived carbon may be absent.

Most of the studies discussed above used 16S rRNA cloning-and-sequencing methods to examine the microbial 
community composition in deep gold mine biosphere. Culture-independent methods, in particular polymerase chain reaction (PCR) and the sequencing of clone libraries are considered the "gold standard" for studying microbial diversity [9]. However, a clone library approach is tedious, time-consuming, and limited by the number of clones sequenced primarily because of the high sequencing cost. Thus, a clone library approach is impractical for generating comprehensive microbial molecular inventory in a given sample. While 16S rRNA clone libraries permit an initial survey of diversity, studies have shown that clone libraries with $<400$ sequences represent only an incomplete sampling of microbial populations and extremely low-abundance organisms remain un-represented [15]. Thus, most published reports on ultra-deep gold mines utilizing cloning-andsequencing reveal only a small portion of the microbial diversity present in a given sample.

Recently with unprecedented progress in microbial ecology, hybridizing PCR products directly (without cloning) to a $16 \mathrm{~S}$ rRNA gene microarray (PhyloChip) has emerged as a rapid, reproducible, and more comprehensive way to analyze microbial diversity in soil, water, and air samples $[4,9,28]$. One of the greatest advantages of using high-density microarrays is their capability to detect individual taxa from an environment that may contain as many as 10,000 different microbial types [40]. In addition, by using sequence-specific PCR, studies have validated that low abundant lineages captured by PhyloChips were indeed present in the original environment, despite their absence in corresponding clone libraries [9]. This highlighted the potential superiority of PhyloChips compared to classical clone libraries. Literature suggests that to date such comprehensive microbial census methods were not applied to explore the microbial diversity in mining-impacted deep biosphere of gold mines and hence these microbial communities remain largely uncharacterized.

The Homestake gold mine $\left(44^{\circ} 35^{\prime} 2074^{\prime \prime} \mathrm{N}, 103^{\circ} 75^{\prime} 082^{\prime \prime} \mathrm{W}\right.$; Lead, SD) is the deepest mine (2.4 km deep) in the North America and had largest gold deposit ever found in the Western Hemisphere. A full description of the mine can be located at Lawrence Berkeley National Laboratory, CA, website http://www.lbl.gov/nsd/homestake/Reference.html). The mine was closed in December 2001 after more than 125 years of mining. On 10th July 2007, the National Science Foundation (USA) announced this mine as a site for the Deep Underground Science and Engineering Laboratory (DUSEL). This former gold mine offers a unique opportunity for direct deep subsurface exploration. In recent studies, we have cultured the cellulose-degrading bacteria [27] and evaluated the microbial diversity in soil samples collected from the Homestake mine using typical 16S clone libraries [30]. Our results showed that majority $(>95 \%)$ of the sequences retrieved in clone libraries were most closely related to environmental sequences from yet-uncultured bacteria representing a hitherto unidentified microbial diversity. In addition, rarefaction analysis of clone library generated non-asymptotic plots which indicated that diversity was not exhaustively sampled due to insufficient clone sequencing, a common problem when assessing environmental microbial diversity by using cloning approaches. Thus, a more sensitive method such as microarrays were required for a comprehensive microbial community composition investigation in deep subsurface habitat of the Homestake mine. Therefore, the purpose of the research was to elucidate the microbial community composition in the soil samples collected from the Homestake mine by applying high-density $16 \mathrm{~S}$ PhyloChips. Furthermore, for the first time, the detailed mineralogical characteristics of soil samples were analyzed using high-resolution techniques such as X-ray diffraction, Xray photoelectron, and Mössbauer spectroscopy. The phylogenetic features of microbial community present in the Homestake mine were compared with corresponding $16 \mathrm{~S}$ clone libraries constructed earlier from the same samples [30] and with those of communities from other deep subsurface environments including ultra-deep gold mines.

\section{Materials and Methods}

\section{Subsurface Soil Sampling}

A schematic cross section and locations of sampling sites in the former Homestake gold mine has been shown in Rastogi et al. [30]. In May 2008, two soil samples were collected corresponding to the Ross shaft and No. 6 Winze of the Homestake mine at a depth of $1.34 \mathrm{~km}$. One sample was directly across the landing from the Ross shaft, one of two primary shafts from the surface into the mine, and one was outside the No. 6 Winze hoist room. Both samples were collected along the junction of the drift wall and the floor, where a small accumulation of soil debris had built up through the years of mining. These areas were not disturbed by any type of activities including human trafficking from June 2003 to May 2008. The outer surfaces of the soil debris built up were discarded and only inner surfaces were collected for microbial diversity analyses using sterile spatulas. This was done to minimize the chances of contamination from exogenous microbes. The temperature at the time of sampling was $26^{\circ} \mathrm{C}$ which was measured using a mercury thermometer. The samples were transported to South Dakota School of Mines and Technology laboratory ( $1 \mathrm{~h}$ drive) in sterile polypropylene bottles on ice and stored at $-20^{\circ} \mathrm{C}$ until analysis. Soil samples were homogenized in sterile pestle and motor inside a laminar flow hood, and then used for geochemical characterization and DNA extraction. 
Mineralogical Characterization of Ross and Winze Soil Samples

The structural characterization of Ross and Winze soils was carried out by Powder X-ray diffraction (XRD) technique for crystalline mineral phases, X-ray photoelectron spectroscopy (XPS) for surface chemical composition and oxidation states, and ${ }^{57} \mathrm{Fe}$-sensitive Mössbauer for $\mathrm{Fe}$ mineralogy. XRD was carried out with a Philips PW3040/ 00 X'Pert MPD system, using $\mathrm{CuK}_{\alpha}$ radiation with a variable divergent slit and a solid-state detector. The Jade+, V5 (Materials Data, Inc., Livermore, CA) software package was used for data analysis. XPS measurements of soil samples were performed using a Physical Electronics Quantum 2000 Scanning ESCA Microprobe. The X-ray beam used was a $100 \mathrm{~W}, 10-\mu \mathrm{m}$ diameter beam that was rastered over a $1.3 \mathrm{~mm}$ by $0.2 \mathrm{~mm}$ rectangle on the sample. Wide scan data was collected using $117.4 \mathrm{eV}$ pass energy. For the $\mathrm{Ag} 3 \mathrm{~d}_{5 / 2}$ line, these conditions produced FWHM (full width at half maximum) of better than $1.6 \mathrm{eV}$. Highenergy resolution spectra were collected using $46.95 \mathrm{eV}$ pass energy. For the $\mathrm{Ag} 3 \mathrm{~d}_{5 / 2}$ line, these conditions produced FWHM of better than $0.98 \mathrm{eV}$. The binding energy (BE) scale was calibrated using the $\mathrm{Cu} 2 \mathrm{p}_{3 / 2}$ feature at $932.62 \pm 0.05 \mathrm{eV}$ and $\mathrm{Au} 4 \mathrm{f}$ at $83.96 \pm 0.05 \mathrm{eV}$ for known standards. The samples experienced variable degrees of charging and low-energy electrons at $\sim 1 \mathrm{eV}, 20 \mu \mathrm{A}$ and low-energy $\mathrm{Ar}^{+}$ions were used to minimize this charging.

Mössbauer spectra were collected at room temperature using a $50-\mathrm{mCi}$ (initial strength) ${ }^{57} \mathrm{Co} / \mathrm{Rh}$ source. The velocity transducer MVT-1000 (WissEL) was operated in a constant acceleration mode $(23 \mathrm{~Hz}, \pm 12 \mathrm{~mm} / \mathrm{s})$. An Ar- $\mathrm{Kr}$ proportional counter was used to detect the radiation transmitted through the holder. Data were folded to give a flat background and a zero-velocity position corresponding to the center shift of a metal $\mathrm{Fe}$ foil at room temperature. Calibration spectra were obtained with a $25-\mu$ m-thick Fe (m) foil and Mössbauer data were modeled with Recoil software (University of Ottawa, Canada) [26].

\section{DNA Extraction, PCR, and PhyloChip Hybridization}

Total DNA was extracted from $200 \mathrm{mg}$ of soil samples in duplicate using a PowerSoil ${ }^{\mathrm{TM}}$ DNA Isolation Kit (MO Bio, Carlsbad, CA) according to the manufacturer's instructions. This DNA isolation kit was used by majority of the previous microbial diversity studies on deep subsurface gold mines [12-14, 21, 23, 24, 30, 38]. Thus, results obtained in our study could be compared with earlier studies with greater confidence. For PhyloChip hybridization, almost full-length bacterial $16 \mathrm{~S}$ genes were amplified using bacteria-specific (63f/1392r) primers [17]. Archael 16S genes were amplified using an archaea-specific (Arch
21f/Arch 958r) primer set which generated a partial amplification of $\sim 950 \mathrm{bp}$ [29]. Efforts to amplify fulllength archael PCR products from Ross and Winze soil samples were unsuccessful despite variation in several parameters (e.g., annealing temperature, alternative primer sets, DNA concentration). Therefore, partial archaeal-16S PCR products were used for microarray hybridization. A control PCR without DNA was set up to check for any contaminants associated with PCR reagents.

Bacterial ( $\sim 500 \mathrm{ng}$ product) and archaeal $(\sim 100 \mathrm{ng}$ product) PCR products amplified from a soil sample were mixed and then concentrated for PhyloChip hybridization. PCR products were prepared for PhyloChip hybridization as described earlier [9]. In brief, PCR products were purified and concentrated to a volume of $40 \mu \mathrm{l}$ using MinElute columns (Qiagen, Valencia, CA). The PCR products were then spiked with known amounts of amplicons derived from prokaryotic metabolic genes. The mixture was then fragmented to 50-200 bp fragment using DNase I (Invitrogen, Carlsbad, CA) followed by labeling with a GeneChip DNA labeling kit (Affymetrix, Santa Clara, CA) as per manufacturer's protocol. The labeled DNA was hybridized to PhyloChips (Affymetrix GeneChips), washed and stained as per standard Affymetrix protocol. For detailed information on microarray design, fabrication, and analytic procedures (background subtraction, detection and quantification criteria, and array normalization) see DeSantis et al. [9]. Operational taxonomic units (OTUs) were classified in phylum, class, order, family, subfamily, and species at sequence similarity cut-off values of $80 \%, 85 \%, 90 \%, 92 \%, 94 \%$, and $97 \%$, respectively [9]. An OTU was considered present in the sample when $90 \%$ or more of its assigned probe pairs for its corresponding probe set were positive (positive fraction of $>0.90)$ [9].

\section{Results}

Mineralogical Characteristics of Ross and Winze Soil Samples

The Powder XRD identified major crystalline phases. Both sample spectra were qualitatively similar to each other (Fig. 1). They were rich in quartz $\left(\mathrm{SiO}_{2}\right)$, chlorite-chamosite $\left[\left(\mathrm{Fe}_{5} \mathrm{Al}\right)\right.$ $\left.\left(\mathrm{AlSi}_{3}\right) \mathrm{O}_{10}(\mathrm{OH})_{8}\right]$, and annite $\left[\mathrm{KFe}_{3} \mathrm{AISi}_{3} \mathrm{O}_{10}(\mathrm{OH})_{2}\right] \mathrm{min}-$ erals; only the major peaks $(100 \%$ intensity) of each mineral phase are indicated by arrows in the Fig. 1. Other minor peaks were due to other reflections of annite, chamosite, and quartz phases and the difference in the peak intensities merely reflect different phase composition. Chamosite was detected in relatively higher amounts than annite in the Ross sample while its amount was lower than annite in the Winze sample. 


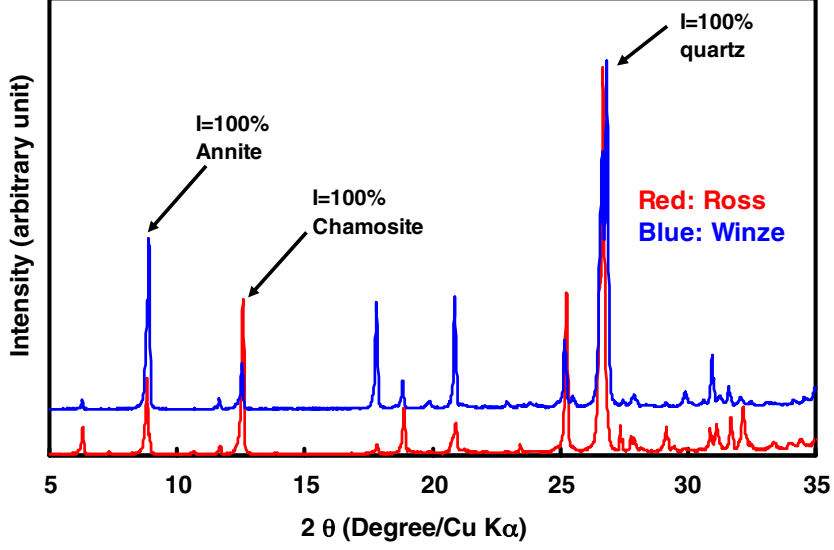

Figure 1 X-ray diffraction patterns of Ross and Winze soils showing major mineral phases of annite, chamosite, and quartz (shown by arrows). XRD patterns identified similar features in both samples. Only $100 \%$ intense peaks were identified by arrows

XPS can quantify surface chemistry and composition by probing a maximum depth of $\sim 10 \mathrm{~nm}$. High-energy resolution photoemission spectra of the $\mathrm{Fe} 2 \mathrm{p}$ region (Fig. 2a) and S2p (Fig. 2b) of both the soil samples were obtained to compare their surface characteristics. The spectra were qualitatively similar to each other, consistent with XRD data. The binding energies of the primary Fe $2 \mathrm{p}_{3 / 2}$ at $(711.4 \mathrm{eV})$ were consistent with $\mathrm{Fe}(\mathrm{III})$ and the lines at $(708.5 \mathrm{eV})$ indicated a small amount of Fe(II) [6]. The Fe satellite peak position $(719.0 \mathrm{eV})$ and line shape was also consistent with mostly $\mathrm{Fe}(\mathrm{III})$. The binding energy for the $\mathrm{S} 2 \mathrm{p}_{3 / 2}$ lines $(169.4 \mathrm{eV})$ was consistent with sulfate. The atomic sulfate concentration in the Winze sample was 3.1 atomic percent as compared with the Ross at 1.3 atomic percent (Fig. 2b).

More detailed insights in the composition of iron minerals were revealed by transmission ${ }^{57} \mathrm{Fe}$-Mössbauer technique (a 57Fe-specific bulk technique; natural abundance of ${ }^{57} \mathrm{Fe}$ is $2.2 \%$ ). Room temperature Mössbauer spectra of the soil samples were similar to each other, hence, only modeled spectrum of Ross soil was shown in Fig. 3a. The similarity of the spectral features was evident from the comparison (Fig. 3b inset); samples mostly differed from each other in relative composition of phyllosilicate minerals, in agreement with XRD. The Mössbauer spectra were rather complex with a wealth of complimentary information. For example, (a) modeling revealed $20 \%$ (Winze) to $45 \%$ (Ross) of the total $\mathrm{Fe}$ as $\mathrm{Fe}$ (II) contributed by chamosite and annite, was significantly different from the surface $\mathrm{Fe}(\mathrm{II})$ and $\mathrm{Fe}(\mathrm{III})$ composition derived from XPS, (b) presence of $\mathrm{Fe}(\mathrm{II})$ and $\mathrm{Fe}$ (III) various environments. The various $\mathrm{Fe}$-environments in phyllosilicates was particularly apparent from the modeling. The $\mathrm{Fe}(\mathrm{II})$ doublets parameters were similar to $\mathrm{Fe}(\mathrm{II})$ in various environments in Fe-rich chlorite mineral (chamo-
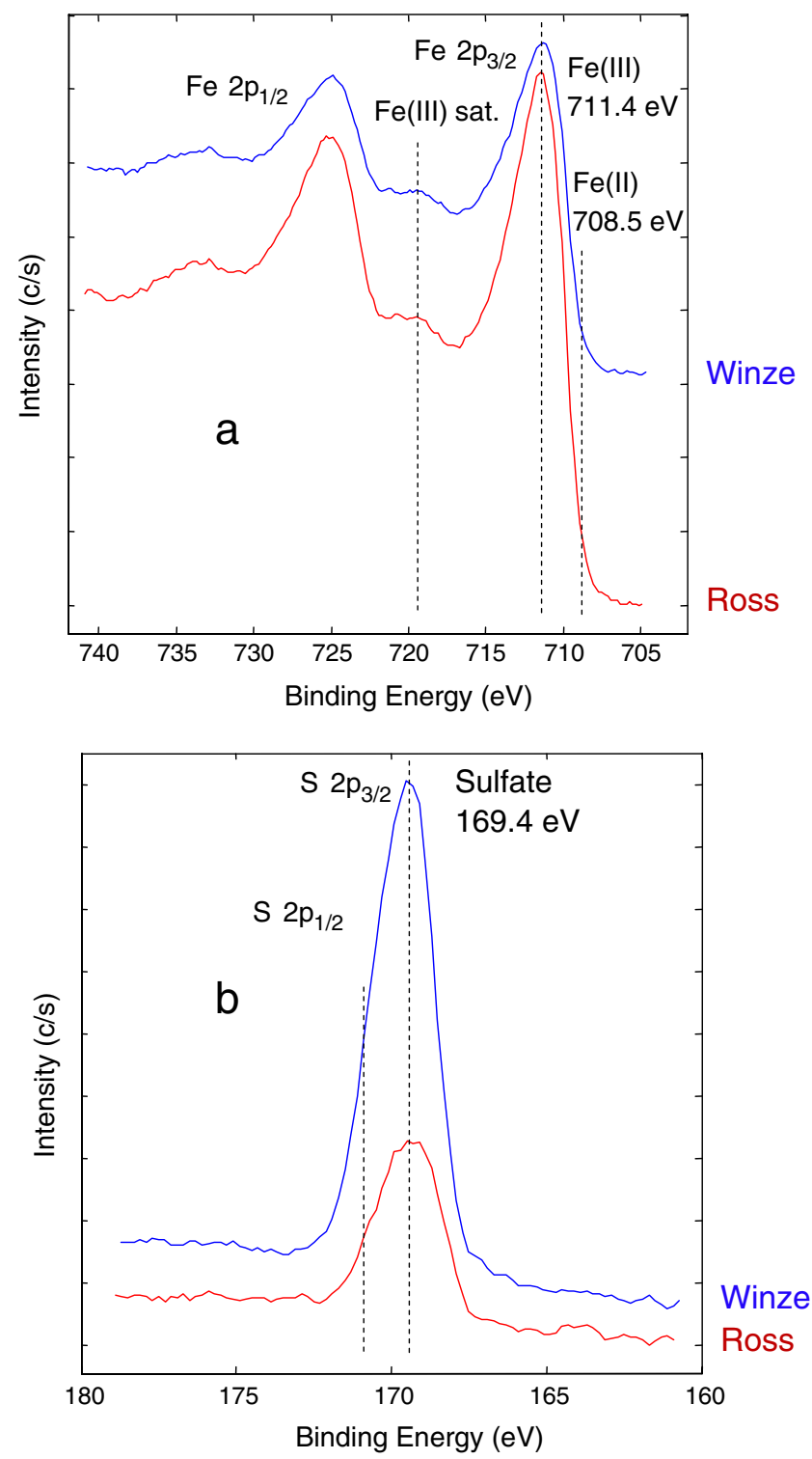

Figure 2 High energy resolution X-ray photoelectron spectra of Ross and Winze soils a $\mathrm{Fe} 2 \mathrm{p}$ region and $\mathbf{b} \mathrm{S} 2 \mathrm{p}$ region showing the presence of $\mathrm{Fe}(\mathrm{II}), \mathrm{Fe}(\mathrm{III})$, and sulfate

site; [32]), and most probably annite [26]. The outer Fe(II) doublet's Mössbauer parameters (blue trace) were characteristic of trans-octahedral $\mathrm{Fe}(\mathrm{II})$ in chlorite (or M2-site). The inner Fe(II) doublet (red trace), however, appeared to be a mixture of cis-octahedaral $\mathrm{Fe}(\mathrm{II})$ in chamosite (or MI site), and most probably some from annite. This assignment was in good agreement with: (a) annite's Mössbauer parameters, (b) inner-to-outer doublet $\mathrm{Fe}(\mathrm{II})$ intensity ratios ( $\sim 1$ in Winze; 0.73 in Ross), which were higher than the pure chamosite $(\sim 0.5$; $[32,41]$ and (c) apparent line-shape of the inner $\mathrm{Fe}(\mathrm{II})$ doublet in the Winze sample. The inner $\mathrm{Fe}(\mathrm{II})$ may also have contributions from $\mathrm{Fe}$ present in the interlayer brucite-like sheets of chlorite [36]. Similarly, the assignment of the $\mathrm{Fe}$ (III) doublet (black trace) was also 
Figure 3 Room temperature Mossbauer spectra: a Modeled spectrum of Ross soil showing peaks due to $\mathrm{Fe}(\mathrm{II})$ and $\mathrm{Fe}(\mathrm{III})$ in chamosite and annite phyllosilicate minerals, and a broad sextet most probably due to small particle or metalsubstituted Fe-oxides, and $\mathbf{b}$ a comparison of both the spectra (unmodeled; inset) showing similar Fe-mineralogy

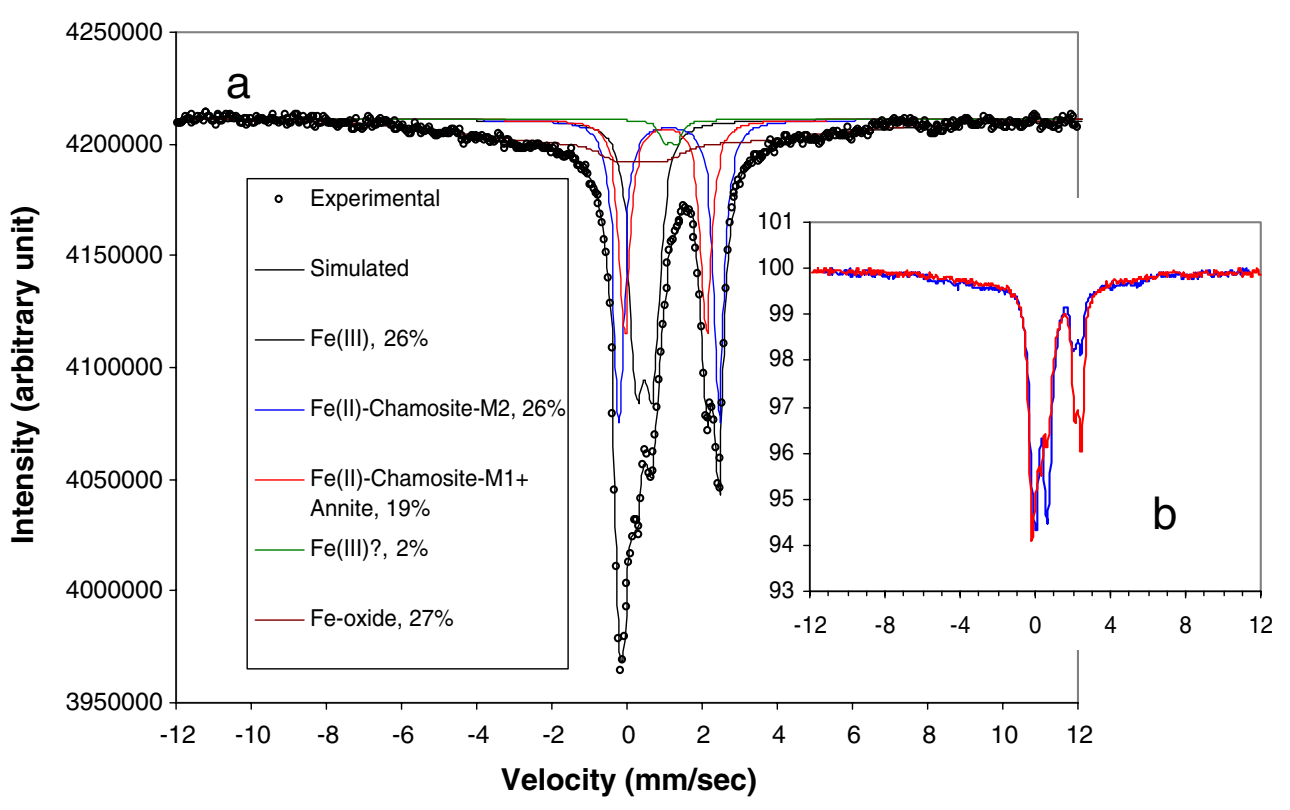

complex, which may have contributions from both octahedral and tetrahedral Fe(III) sites of annite and chamosite, and small-particle (superparamagnetic) Fe-oxide [22]. The broad sextet (brown trace) which was one-third of the total $\mathrm{Fe}$ in both the samples was probably due to metalsubstituted Fe-oxides (goethite and/or hematite substituted with $\mathrm{Al}$ ) [22]. These iron oxides were either in amorphous forms or were present in small quantities, since they were not evident in XRD spectra. Absence of sulfide in XPS data also implied the absence of Fe-sulfide minerals in these soil samples.

Deep Biosphere Communities in the Ross Site of the Homestake Mine

PhyloChip proved extremely sensitive in capturing biosignatures at all taxonomic levels and detected a total of 1,511 OTUs positioned within 44 phyla which also included two archaeal phyla namely the Euryarchaeota and Crenarchaeota (Table 1). These 44 phyla contained diverse taxonomic lineages encompassing 49 classes, 91 orders, and 149 families. Among the 1,511 OTUs captured on the PhyloChip, a total of 25 OTUs were considered unclassified at the phylum level because of their low similarities $(<80 \%)$ with reference probes on PhyloChip (Table 1). For a comprehensive distribution of bacterial and archaeal OTUs among different classes/orders/families/ genera see supplementary tables (Electronic Supplementary Materials, Supplementary Class Table 1; Supplementary Order Table 2; Supplementary Family Table 3, and Supplementary Genera Table 4). PhyloChip data demonstrated that Proteobacteria was the most abundant taxa than other phyla, accounting for almost $49 \%$ of the total OTUs detected (Table 1). The Firmicutes (15\% of total OTUs) and
Actinobacteria (11\% of total OTUs) represented the next most abundant phyla on PhyloChip.

Deep Biosphere Communities in the Winze Site of the Homestake Mine

The PhyloChip provided a comprehensive view of microbial diversity and captured a total of 1,678 OTUs spanning 44 phyla, 51 classes, 97 orders, and 154 families in Winze soil sample (Table 1). For a comprehensive distribution of these OTUs among different classes/ orders/families/genera see supplementary tables (Electronic Supplementary Materials, Supplementary Class Table 1; Supplementary Order Table 2; Supplementary Family Table 3, and Supplementary Genera Table 4). Of the 1,678 bacterial OTUs detected, a total of 32 OTUs were considered as unclassified at the phylum level (Table 1). Like Ross soil, PhyloChip data for Winze soil indicated that Proteobacteria was far more abundant than other phyla, accounting for almost $47 \%$ of the total OTUs detected. The Firmicutes (15\% of total OTUs) and the Actinobacteria (12\% of total OTUs) represented the next most dominant phyla on the PhyloChip (Table 1).

\section{Discussion}

Comparative Species Richness in the Ross and Winze Soils of the Homestake Mine

PhyloChip analysis confirmed the presence of all taxa detected in corresponding $16 \mathrm{~S}$ clone libraries established earlier from the same samples and additionally demonstrated greater phylotype diversity extending into phyla not observed 
Table 1 Bacterial and archael phyla detected in the Ross and Winze sites using PhyloChip analyses
Serial no. Bacterial/archael phyla detected on PhyloChips

\begin{tabular}{|c|c|c|c|}
\hline & & \\
\hline & & Ross site & Winze site \\
\hline 1. & Acidobacteria & 57 & 60 \\
\hline 2. & Actinobacteria & 162 & 198 \\
\hline 3. & $A D 3$ & 1 & 1 \\
\hline 4. & Aquificae & 4 & 3 \\
\hline 5. & Bacteroidetes & 77 & 76 \\
\hline 6. & $B R C 1$ & 2 & 1 \\
\hline 7. & Caldithrix & 2 & 2 \\
\hline 8. & Chlamydiae & 2 & 2 \\
\hline 9. & Chlorobi & 9 & 10 \\
\hline 10. & Chloroflexi & 41 & 38 \\
\hline 11. & Coprothermobacteria & 1 & 1 \\
\hline 12. & Crenarchaeota $^{\mathrm{b}}$ & 2 & 3 \\
\hline 13. & Cyanobacteria & 33 & 46 \\
\hline 14. & Deinococcus-Thermus & 4 & 4 \\
\hline 15. & Dictyoglomi & 1 & 1 \\
\hline 16. & DSS1 & 1 & 1 \\
\hline 17. & Euryarchaeota $^{\mathrm{b}}$ & 1 & 3 \\
\hline 18. & Firmicutes & 231 & 260 \\
\hline 19. & Gemmatimonadetes & 9 & 9 \\
\hline 20. & LDIPA group & 1 & 1 \\
\hline 21. & Lentisphaerae & 3 & 3 \\
\hline 22. & marine group $A$ & 1 & 2 \\
\hline 23. & Natronoanaerobium & 4 & 5 \\
\hline 24. & NC10 & 1 & 1 \\
\hline 25. & Nitrospirae & 10 & 10 \\
\hline 26. & $O D 1$ & 1 & 1 \\
\hline 27. & OP10 & 4 & 5 \\
\hline 28. & $O P 3$ & 3 & 3 \\
\hline 29. & OP8 & 2 & 1 \\
\hline 30. & OP9/JS1 & 5 & 2 \\
\hline 31. & Planctomycetes & 15 & 11 \\
\hline 32. & Proteobacteria $^{\mathrm{c}}$ & 732 & 807 \\
\hline 33. & SPAM & 2 & 2 \\
\hline 34. & Spirochaetes & 24 & 35 \\
\hline 35. & Synergistes & 5 & 5 \\
\hline 36. & Termite group 1 & 2 & 3 \\
\hline 37. & Thermodesulfobacteria & 1 & 1 \\
\hline 38. & Thermotogae & 1 & 1 \\
\hline 39. & TM6 & 1 & 1 \\
\hline 40. & $T M 7$ & 5 & 5 \\
\hline 41. & Unclassified $^{\mathrm{a}}$ & 25 & 32 \\
\hline 42. & Verrucomicrobia & 20 & 19 \\
\hline 43. & $W S 3$ & 2 & 2 \\
\hline 44. & WS5 & 1 & 1 \\
\hline
\end{tabular}

Distribution of OTUs among different phyla

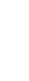

A total of 1,511 and 1,678 OTUs found at the Ross and Winze sites, respectively, were distributed in 44 phyla. Phylum printed in bold are those that have been reported earlier from deep subsurface gold mine environments $[13,23,24$, $28,38]$

${ }^{\mathrm{a}}$ A total of 25 and 32 OTUs in the Ross and Winze sites, respectively, could not be assigned to any known phylum and were considered unclassified

${ }^{\mathrm{b}}$ Phylum belonging to kingdom Archaea

${ }^{\mathrm{c}}$ Most abundant phylum in the Ross and Winze sites 
by cloning methods [30]. PhyloChip analysis of soil samples obtained from Ross and Winze sites demonstrated 1,511 and 1,678 OTUs, respectively. Comparative PhyloChip data analyses showed that Ross and Winze samples shared large number $(1,360)$ of OTUs in common with only 151 and 318 OTUs exclusively present in Ross and Winze samples, respectively (Fig. 4a). Despite of differences in the physical and chemical composition, both sites had similar microbial communities. Our previous clone library results showed that Ross site had relatively more species richness (110 OTUs) than the Winze site (100 OTUs) as indicated by the number of phylotypes retrieved from the same library sizes (165 clones in each library) [30]. Contrary to earlier clone library data, microarray data showed that Winze site (1678 OTUs) had more species richness than the Ross site $(1,511$ OTUs). We assume that this was primarily due to the limited number of clones analyzed in our previous study and sequencing of additional clones would have presented more in-depth picture of microbial diversity present in these sites.

A strong linear correlation has been shown earlier between microarray probe set intensity and concentration of OTU-specific 16S rRNA gene copies, which allows relative abundance analysis between normalized PhyloChips [5]. Interestingly, relative abundance based on the fluorescence intensity of OTU probe sets for Ross and Winze samples identified specific bacterial groups which were significantly different between two sites. Bacterial taxa demonstrating significant changes in intensity between Ross and Winze are depicted in Fig. 4b. Though both samples, shared a majority of OTUs, differences in bacterial abundances were observed. We used same DNA extraction protocol for both soil samples therefore assuming the equal extraction efficiencies of various taxa in both soil samples, Actinobacteria and bacilli were relatively more abundant in Winze sample as compared to Ross sample. On the other hand bacteria belonging to $\beta$-proteobacteria, $\gamma$-proteobacteria, $\delta$-proteobacteria, and clostridia were found to be more abundant in Ross sample compared to Winze (Fig. 4b).

Effects of Metals, $\mathrm{pH}$, and Mineral Phases on Microbial Communities

To our surprise, microarray analyses detected a broad phylogenetic diversity in soil samples despite the presence of significant amount of toxic metals and absence of sunlight-irradiation. In our previous study [30], we showed the detailed geochemical characteristics of these soil samples using X-ray fluorescence spectroscopy, coupled plasma optical emission spectrometry, and inductively coupled plasma mass spectroscopy. Our results showed that a significant amounts of toxic metals such as $\mathrm{As}, \mathrm{Cd}$, $\mathrm{Co}, \mathrm{Cr}, \mathrm{Cu}, \mathrm{Ni}, \mathrm{Pb}$, and $\mathrm{Zn}$ were present in Ross and Winze soil samples. However, the water soluble (bioavailable) concentrations of these toxic metals were very low $(<0.3 \mathrm{mg} / \mathrm{l})$. Metals are toxic only in their ionic form and $\mathrm{pH}$ has been shown a most crucial factor in determining the bioavailability [31]. Roane and Kellogg [31], while studying the bioavailability of $\mathrm{Pb}$ in mining-impacted soil samples, showed that soluble toxic $\mathrm{Pb}$ concentrations were only detectable in acidic soils. Both the soil samples analyzed in our study had near neutral $\mathrm{pH}$ (6.6-6.7) [30] due to which bioavailable metal concentrations will decrease resulting in to less or no toxic effects on the inhabitant deep subsurface microbial communities.
Figure 4 a Venn diagram showing fraction of similar OTUs observed between the Ross and Winze samples. The number in the circle indicates the estimated numbers of OTUs that are shared between two samples. b Comparison of relative abundance of taxa based on fluorescence intensity of OTU probes in Ross and Winze samples. OTUs were arranged based on their taxonomic affiliations. Bars above the zero line represent increased abundance in Winze sample relative in Ross sample while bars below represent relative decline in abundance in Winze sample

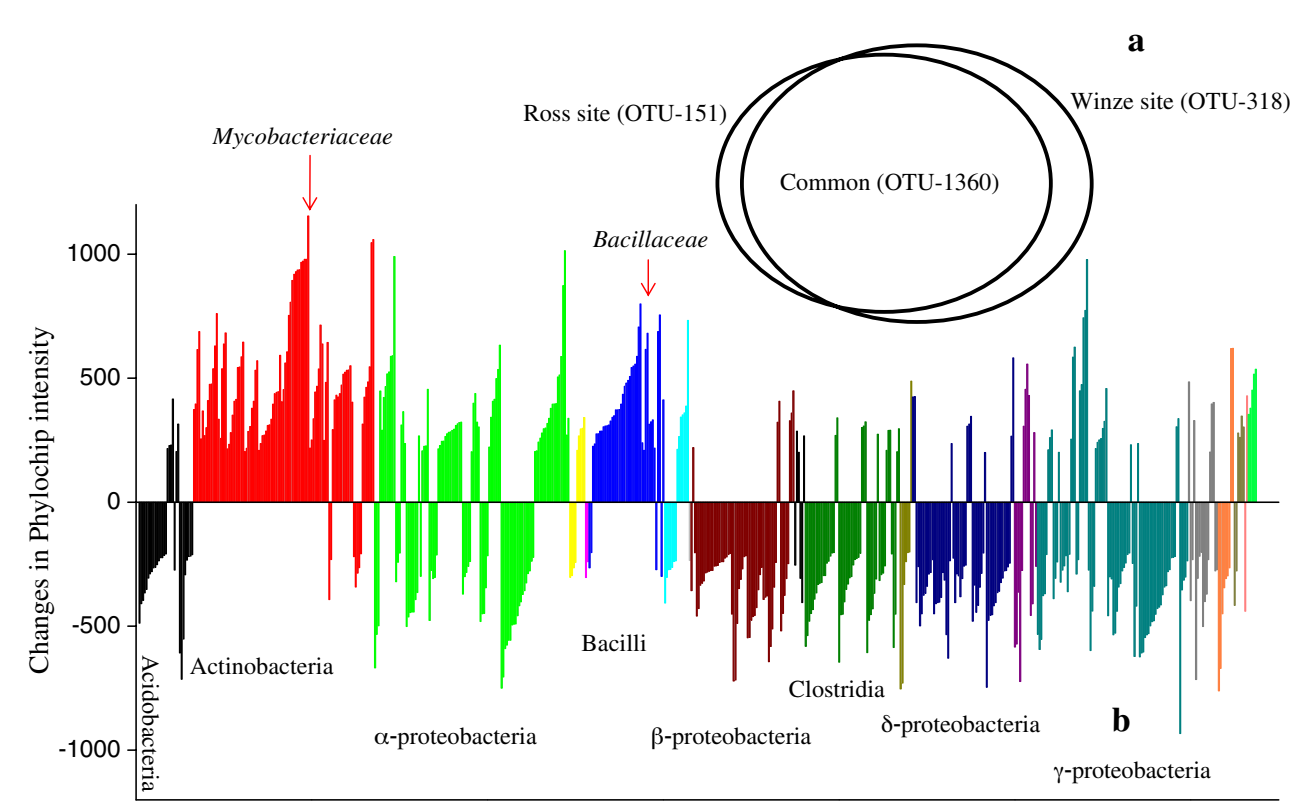


In addition to $\mathrm{pH}$, another important factor controlling metal bioavailability in deep biosphere could be the presence of several complex mineral phases. XRD, XPS, and Mössbauer data indicated the presence of various minerals including chamosite, annite, and unidentified amorphous metal-substituted iron oxides. The surfaces of soil minerals have strong metal ions adsorptive capabilities and therefore may have reduced aqueous concentrations to a non-toxic levels, and decreasing overall metal bioavailability and toxicity $[33,34]$. In subsurface soil, ferric oxides and oxyhydroxides (e.g., hematite, goethite, ferrihydrite) commonly exists as soil minerals. These minerals have strong affinity for a large number of cations and anions primarily due to their amorphous nature and high surface area [35]. Pertinent to this, our recent study on $\mathrm{Pb}$ toxicity to Desulfovibrio desulfuricans G20 also showed that in presence of goethite and quartz, $\mathrm{Pb}$ toxicity decreased significantly [34]. However, we acknowledge here that accurate effects of metal stress on microbial diversity can be predicted only when control soil samples from uncontaminated areas are also included in analysis. Such microbial diversity surveys with control samples will also help in identifying those taxa that are uniquely present or more dominant in mining-impacted soils.

Subsurface Microbial Community Composition in the Homestake Mine

To date, earlier studies on ultra-deep gold mines utilized clone libraries and culture-based approach to decipher the microbial community composition and so far no study has reported in-depth characterization of microbial diversity in deep subsurface of gold mines. PhyloChips captured lineages previously reported from ultra-deep gold mines and additionally helped recognize the presence of yet to be identified bacterial lineages at each taxonomic level in both samples. Compared to the microbial diversity assessments from other deep subsurface gold-mines [13, 14, 23, 25, 38], our results showed remarkable similarities at phylum level. The phyla in common were Euryarchaeota, Crenarchaeota, Acidobacteria, Actinobacteria, Bacteroidetes, Chlorobi, Chloroflexi, Firmicutes, Gemmatimonadetes, Nitrospirae, Proteobacteria, and candidate divisions OP10 and TM7 (Table 1). However, this is the first report for the presence of members of phyla AD3, BRC1, Cladithrix, Coprothermobacteria, Cyanobacteria, Deferribacters, Dictyoglomi, DSS1, LD1PA group, Lentisphaerae, marine group A, NC10, OP3,OP8, OP9, OP10, SPAM, SR1, Synergists, Thermotogae, termite group 1, TM6, TM7, WS3, and WS5 in ultra-deep gold mines (Table 1). Candidate phyla; OP10 and TM7 sequences were retrieved in $16 \mathrm{~S}$ clone libraries constructed earlier from Homestake mine soil samples [30].
Earlier studies have shown that Proteobacteria constituted a major proportion of the clone libraries established from deep subsurface gold mines samples $[13,25,30]$. The PhyloChip results in this study agreed with earlier reports as Proteobacteria-related lineages constituted the most abundant group in both the samples. The ubiquitous nature of the Proteobacteria is mostly due to their capabilities to cope with hostile life conditions such as high temperature and pressure, extreme $\mathrm{pH}$, oligotrophic environments, metalreduction, and metal-resistance which are prerequisite to surviving in mining-impacted deep subsurface environments [1]. Proteobacterial genera documented in Ross and Winze sites such as Acinetobacter, Burkholderia, and Ralstonia (Electronic Supplementary Material, Supplementary Genera Table 4) have been reported earlier from metal-contaminated environments and are resistant to metals such as cadmium, copper, nickel, and zinc $[1,29]$ suggesting that abundance of toxic metals in mining-impacted Ross and Winze soils may have selected these genera. It is interesting to note that within the Proteobacteria, PhyloChips have identified genera belonging to $\alpha$-Proteobacteria (e.g., Sphingomonas, Rhodobacter, Caulobacter, Methylobacterium, Brevundimonas, Bradyrhizobium), $\beta$-Proteobacteria (e.g., Azoarcus, Acidovorax, Nitrosomonas, Thiobacillus, Comamonas), $\gamma$ -Proteobacteria; (e.g., Pseudomonas, Thiocapsa, Nevskia, Methylococcus, Marinobacter, Stenotrophomonas, Halomonas, and $\delta$ - Proteobacteria (e.g., Desulfovibrio) that have been described earlier from ultra-deep gold mines of Japan and South Africa [13, 14, 25]. Additionally, bacteria such as Shewanella surugensis detected in Ross and Winze sites were previously cultured from deep-sea sediments [20]. These genera indicate an original deep biosphere ecosystem in the Homestake mine. Noticeably, the Homestake mine is geographically distinct from previously studied ultra-deep gold mines or deep subsurface habitats. Thus it was interesting to note such similarities in retrieved phylotypes of the Homestake mine with other deep subsurface environments. In addition to retrieving deep biosphere microbial signatures, PhyloChip also indicated several bacteria (e.g., Roseobacter) from the Ross and Winze sites that have not been previously reported from deep subsurface or metal-contaminated environments (Electronic Supplementary Material, Supplementary Genera Table 4). Such genera have been widely shown in pristine environments [15] and probably would have been introduced in Homestake mine deep biosphere during mining operations.

In addition to identifying major taxa such as Proteobacteria, Firmicutes, and Actinobacteria, PhyloChips also captured other minor phyla such as Gemmatimonadetes, Nitrospirae, Planctomycetes, Spirochaetes, and Verrucomicrobia in both the sites. Although, these phyla have been reported earlier from ultra-deep gold mines $[13,14,25,30]$, their roles in the 
ecology of deep biosphere remain unclear. Our study demonstrated very low archaeal diversity (only 3-6 OTUs in Archaea domain) in the Homestake mine deep biosphere which agreed well with our previous $16 \mathrm{~S}$ clone library results which demonstrated only few archael lineages in Ross and Winze samples [30]. It is also likely that low archael diversity observed could be due to partial $16 \mathrm{~S}$ amplicons used for microarray hybridization. The reference $16 \mathrm{~S}$ probes attached on PhyloChips were based on sequence information from nearly complete $(\sim 1,325 \mathrm{bp}) 16 \mathrm{~S}$ rRNA genes. Therefore, PhyloChip analysis using partial archael 16S PCR products (as generated by Arch 21f/Arch 958r) would have missed hybridization of PCR amplicons with several 16S probes present on the PhyloChip and hence the "present" call for several archael OTUs.

Microarrays also indicated several phylotypes related to phyla for which no cultivated representatives are known. For example in the Ross and Winze sites, phylotype similar to sequences from candidate phyla, e.g., OP3, OP9, OP10, TM6, and TM7 were retrieved. To date no cultivable lineages belonging to these candidate divisions have been isolated in cultures [15]. These bacterial divisions are exclusively represented by environmental sequence data and are unstudied. Other phyla such as Acidobacteria and Verrucomicrobia contain only few cultured members [15]. Therefore, the physiological roles of any of these bacteria in natural environments including in deep subsurface ecology remain unknown. Our study has avoided over data interpretation based solely on PhyloChip data. Nevertheless, a species molecular inventory is an important initial step in describing unique and dynamic microbial communities, and forms basis for the development of improved culturing methods, and subsequently, elucidation of metabolic roles.

Metabolic Versatility in Deep Biosphere of the Homestake Mine

Deep subsurface environments are generally considered as oligotrophic due to the lack of photosynthetically derived electron donors [16]. Geochemical conditions in the subsurface biosphere such as nutrient availability and permeability, soil composition, redox potential, and a variety of other factors generally influence the resident microbial communities. In such environments the geothermal aquifer is the major source of carbon (e.g., methane, carbon dioxide) and energy (e.g., hydrogen, sulfide, reduced iron, and ammonium), and acts as a determinant for microbial community structures. Chemolithoautotrophic microorganisms in deep subsurface that could grow on hydrogen and carbon dioxide (e.g., acetogenic bacteria) can act as primary producers, initiating heterotrophic food chains independent of photosynthesis [16]. Active chemo- lithotrophic bacteria in the ultra-deep gold mines of South Africa and Japan have been reported earlier [3, 23, 38]. These studies have also demonstrated sulfate-reducing and methanogenic metabolic pathways in deep biosphere of gold mines. More interestingly, viable sulfate-reducers, methanotrophs, ammonia-oxidizers, nitrite-oxidizers, methane-oxidizers, and sulfur-oxidizers have been isolated from geothermal water sampled from deep Japanese gold mines [13].

Precambrian aquifer water was pumped continuously for dewatering during the operation of the Homestake mine and in June 2003, pumps were turned off. Current water inflow to the underground is about $2,839 \mathrm{~L}$ $\min ^{-1}[8]$. Geothermal water enters the Homestake mine from the surface primarily through the shaft and airways that intersect with the open pit. Our previous study, reported a variety of soluble ions (such as $\mathrm{SO}_{4}{ }^{-}[9,237-$ $\left.15,156 \mathrm{mg} \mathrm{L}^{-1}\right]$, and $\mathrm{NO}_{3}^{-}\left[16-39 \mathrm{mg} \mathrm{L}^{-1}\right]$ ) in soils collected from the Ross and Winze sites of the Homestake mine [30]. In present study, soil XPS analysis also identified considerable sulfur mainly in form of $\mathrm{SO}_{4}{ }^{-}$ ions. These soluble ions can fuel the growth of various chemotrophic microorganisms in deep Homestake mine biosphere where the energy sources are limited. For example, PhyloChip has indicated several chemolithotrophic genera such as ammonia-oxidizers (e.g., Nitrosomonas sp.), nitriteoxidizers (e.g., Nitrospira sp.), methane-oxidizers (e.g., Methylosinus sp.), sulfur-oxidizers (e.g., Thiobacillus sp), methanogens (e.g., Methanosarcina sp.), and sulfatereducers (e.g., Desulfosporoinus sp.) in Ross and Winze soils samples. Interestingly, our laboratory enrichment studies for sulfate-reducing bacteria using acetate and sulfate as electron donor and acceptor, respectively, confirmed the existence of viable population of sulfate-reducers in Ross and Winze soil samples. A $16 \mathrm{~S}$ clone library analysis of the enrichment culture revealed that Desulfosporosinus spp. were the dominant lineages in the sulfate-reducing enrichment (Rastogi et al., unpublished data).

The gold deposits at the Homestake mine are typically associated with the banded ironstone formation [2] therefore both soil samples contained very high amount of iron; 51,540-75,657 $\mathrm{mg} \mathrm{L}^{-1}$ [30]. In this study, XPS and Mössbauer data clearly showed the presence of reduced iron [Fe(II)]. As expected, PhyloChip detected several Feoxidizing bacteria (e.g., Leptothrix, Acidithiobacillus) in both soil samples. These bacteria proliferate in habitats where anaerobic $\mathrm{Fe}(\mathrm{II})$-rich water comes in the contact of air. During dewatering of the Homestake mine for the construction of DUSEL, the exposed oxygenated Fe(II)-rich surfaces served as a primary site for the growth of these bacteria, evident by the characteristic rust colored soil samples from insoluble Fe(III)-ions [30]. Room temperature Mossbauer spectra showed $>25 \%$ of the iron in form of 
oxidized Fe(III)-ions. In addition to Fe-oxidizing bacteria, microarrays also captured few $\mathrm{Fe}(\mathrm{III})$-reducing bacteria such as Shewanella sp. in both site that can reduce variety of terminal electron acceptors, including nitrate, nitrite, thiosulfate, and elemental sulfur [11]. In a $16 \mathrm{~S}$ clone library of Fe-reducing enrichment cultures initiated using Ross and Winze soils with acetate and hematite as electron donor and acceptor, respectively showed that Clostridium sp. dominated the iron-reducing communities (Rastogi et al. unpublished data). PhyloChips also indicated Clostridium-related OTUs in both soil samples (Electronic Supplementary Material, Supplementary Genera Table 4).

Another important chemotrophic group of bacteria in the Homestake mine could be sulfur-oxidizers because of the significant amount of sulfur (as shown by XPS) present in soil samples. Chemical characterization of Ross and Winze soil also showed significant sulfur (1.79-2.66\%; measured as total sulfur) which can act as energy source for these bacteria [30]. As a proof to this hypothesis, we have cultured sulfuroxidizing bacteria belonging to genus Thiobacillus from Ross and Winze soil samples (Rastogi et al., unpublished data). PhyloChip data also demonstrated the presence of Thiobacillus sp. in soil samples. Interestingly, Thiobacilli are chemolithoautotrophic, sulfur-oxidizing bacteria that are restricted to habitats where both an electron donor (reduced sulfur compounds $\left[\mathrm{S}^{0}, \mathrm{H}_{2} \mathrm{~S}\right.$, and $\left.\mathrm{S}_{2} \mathrm{O}_{3}{ }^{-2}\right]$ or $\mathrm{Fe}$ (II) in some cases) and an electron acceptor $\left(\mathrm{O}_{2}\right.$ or $\left.\mathrm{NO}_{\mathrm{x}}\right)$ simultaneously exist. These bacteria produce sulfuric acid and $\mathrm{Fe}(\mathrm{III})$ as by-products of their metabolism and play a very important role in biomineralization. Southam et al. [37] further demonstrated a very strong physical association between Thiobacillus species and the sulfide minerals, which helps account for their prominence in tailings environments.

Alternative carbon sources such as lignocelluloses may also fuel the Homestake mine deep biosphere. During active mining-operations for over 125 years, lignocellulosic substrates were introduced into the Homestake mine [27]. Interestingly, we have isolated several strains of Bacillus, Paenibacillus, and Geobacillus from the Homestake mine that were able to grow on cellulose and sawdust (a fine powder of woodchips) as a source of carbon and energy [27]. All these genera have been captured by PhyloChips which indicates that Homestake mine deep biosphere harbors microbial communities that can use complex lignocellulosic materials as carbon and energy sources.

Molecular-based diversity methods (e.g., PCR, cloning-and-sequencing, PhyloChip) based on direct DNA/RNA-extraction are alternative to classical culturebased methods, and have provided great insights in to community composition, richness, and structure of microbial communities. However, like culture-based methods, these molecular methods have their own pitfalls and are associated with bias at every step. Bias associated with DNA extraction (e.g., incomplete/no lyses of microbial cells) can distort the revealed community composition, richness, and microbial community structure [10]. In addition, all PCRbased diversity studies have additional biases associated which include primer choice, annealing temperature, and preferential amplification of certain templates [39].

DNA extraction from environmental samples constitutes the first step in PCR-based community analysis. In fact, different DNA recovery methods have been shown to reveal different depth of microbial diversity due to variation in the ability to break open cells/spores [18]. Different studies have used different DNA extraction protocols in soil microbial diversity analysis. The primary reason so many methods for DNA extraction have been used is due to the fact that most procedures are optimized for a specific soil. This implies that any given procedure may not be universally applicable to all soils due to inherent spatial and microbial heterogeneity [42]. Use of a standard DNA extraction protocol which is efficient for a soil sample may or may not work for other samples sometimes even collected from the same site. DNA extraction efficiency is correlated with soil's physicochemical characteristics (texture, particle size), inhibitors (humic acids, metals, organic legends, etc.), and type of microbial communities.

Feinstein et al. [10] demonstrated that biases in community analysis can be reduced in many situations by pooling three successive DNA yields from a recovery method. Another study by McIlroy et al. [19] suggested use of several validated DNA extraction methods and pooled DNA extracts to minimize any risk of bias. Use of such validated protocols by all microbial ecologists could provide a more complete understanding of the soil microbial community composition and would offer a platform where quantitative inter-comparisons can be made [18]. In addition, development of a single method for purification of DNA from all soil samples will be a great step toward automating the procedures, and for standardizing results between laboratories. A procedure that is equally efficient for all soil samples, efficiently lyses all bacterial groups, requires little time to complete, and is easy to processing multiple samples simultaneously would be highly desirable. For example, MoBio PowerSoil ${ }^{\mathrm{TM}}$ DNA isolation kit which is also used in our study is very widely used method for isolating microbial DNA of the highest quality and purity from most environmental samples including deep subsurface gold mines. An advantage of using commercially available kits for DNA isolation is that they provide a rapid and standardized approach that can be quickly learned. Nonetheless, working with complex environmental samples, e.g., soil where $>99 \%$ microorganisms have not been cultured yet; it is difficult to predict the efficiency of MoBio PowerSoil $^{\mathrm{TM}}$ kit for those uncultured organisms. In 
addition, it would be worth to acknowledge that although, microarray technology has been used for specific, quantitative, and high-throughput detection of microbial diversity in natural settings; it is unreliable in identifying and detecting novel prokaryotic taxa. The ecological importance of a species, which may be abundant and pivotal to the ecosystem under study, can be completely ignored if the species does not have a corresponding probe on the PhyloChip. Furthermore, community analysis using molecular methods alone is not sufficient for predicting the metabolic functions within the environment.

In summary, the present study provided a comprehensive microbial census on the bacterial and archael communities in the mining-impacted deep subsurface habitat of the Homestake mine. In comparison to previous studies, the use of high-density microarrays resulted in identification of enormous phylogenetic diversity from ultra-deep gold mines. We acknowledge here that molecular oxygen and surface microbes were introduced into the Homestake mine by human activities during mining-operations, thus the microbial community in soil samples does not necessarily reflect an indigenous deep subsurface microbial population. However, various environmental limitations in the deep biosphere of the Homestake mine would shape the microbial diversity as a novel and unique subsurface microbial ecosystem. The results on microbial diversity and geochemistry will serve as a vital comparison for future assessment of changes in microbial diversity and geochemistry as re-entry in Homestake mine continues and the deeper levels become exposed during the construction of the DUSEL.

Acknowledgements This research was funded by the South Dakota Board of Regents Competitive Research Grant (Award No. SDBOR/ SDSMT 2010-09-05). Powder XRD, XPS, and Mössbauer spectroscopy measurements were conducted using EMSL, a national scientific user facility sponsored by the Department of Energy's Office of Biological and Environmental Research located at Pacific Northwest National Laboratory. We would like to acknowledge Colleen Russell (PNNL) for her help in XRD measurements and Mössbauer sample preparations. Authors appreciate the assistance provided by Dr. L. D. Stetler of Department of Geology and Geological Engineering, SDSM\&T in sample collection. We also would like to thank the anonymous reviewers whose critiques were instrumental in improving the quality of manuscript.

\section{References}

1. Akob DM, Mills HJ, Kostka JE (2007) Metabolically active microbial communities in uranium-contaminated subsurface sediments. FEMS Microbiol Ecol 59:95-107

2. Bachman RL, Caddey SW (1990) The Homestake mine, lead, South Dakota: an overview. In: Paterson CJ, Lisenbee AL (eds) Metallogeny of gold in the Black Hills, South Dakota. Society of Economic Geologists Guidebook Series, v. 7, pp. 129-135
3. Baker BJ, Moser DP, MacGregor BJ, Fishbain S, Wagner M, Fry NK, Jackson B, Speolstra N, Loos S, Takai K, Lollar BS, Fredrickson J, Balkwill D, Onstott TC, Wimpee CF, Stahl DA (2003) Related assemblages of sulphate-reducing bacteria associated with ultradeep gold mines of South Africa and deep basalt aquifers of Washington State. Environ Microbiol 5:267-277

4. Brodie EL, Desantis TZ, Joyner DC, Baek SM, Larsen JT, Andersen GL, Hazen TC, Richardson PM, Herman DJ, Tokunaga TK, Wan JM, Firestone MK (2006) Application of a high-density oligonucleotide microarray approach to study bacterial population dynamics during uranium reduction and reoxidation. Appl Environ Microbiol 72:6288-6298

5. Brodie EL, DeSantis TZ, Parker JP, Zubietta IX, Piceno YM, Andersen GL (2007) Urban aerosols harbor diverse and dynamic bacterial populations. Proc Natl Acad Sci USA 104:299-304

6. Chambers SA, Kim YJ, Gao Y (2008) Fe2p core-level spectra for pure, epitaxial $\alpha-\mathrm{Fe}_{2} \mathrm{O}_{3}(0001), \gamma-\mathrm{Fe}_{2} \mathrm{O}_{3}(001)$, and $\mathrm{Fe}_{3} \mathrm{O}_{4}(001)$. Surf Sci Spectra 5:219-228

7. Chivian D, Brodie EL, Alm EJ, Culley DE, Dehal PS, DeSantis TZ, Gihring TM, Lapidus A, Lin LH, Lowry SR, Moser DP, Richardson PM, Southam G, Wanger G, Pratt LM, Andersen GL, Hazen TC, Brockman FJ, Arkin AP, Onstott TC (2008) Environmental genomics reveals a single-species ecosystem deep within Earth. Science 10:275-278

8. Davis A, Roggenthen W, Stetler L, Hladysz Z, Johnson C (2009) Post-closure flooding of the Homestake mine at Lead, South Dakota. Mining Engineering, March. pp. 43-47

9. DeSantis TZ, Brodie EL, Moberg JP, Zubieta IX, Piceno YM, Andersen GL (2007) High-density universal 16S rRNA microarray analysis reveals broader diversity than typical clone library when sampling the environment. Microb Ecol 53:371-383

10. Feinstein LM, Sul WJ, Blackwood CB (2009) Assessment of bias associated with incomplete extraction of microbial DNA from soil. Appl Environ Microbiol 75:5428-5433

11. Fredrickson JK, Romine MF, Beliaev AS, Auchtung JM, Driscoll ME, Gardner TS, Nealson KH, Osterman AL, Pinchuk G, Reed JL, Rodionov DA, Rodrigues JL, Saffarini DA, Serres MH, Spormann AM, Zhulin IB, Tiedje JM (2008) Towards environmental systems biology of Shewanella. Nat Rev Microbiol 6:592-603

12. Gihring TM, Moser DP, Lin L-H, Davidson M, Onstott TC, Morgan L, Milleson M, Kieft TL, Trimarco E, Balkwill DL, Dollhopf ME (2006) The distribution of microbial taxa in the subsurface water of the Kalahari Shield, South Africa. Geomicrobiol J 23:415-430

13. Hirayama H, Takai K, Inagaki F, Yamato Y, Suzuki M, Nealson $\mathrm{KH}$, Horikoshi K (2005) Bacterial community shift along a subsurface geothermal water stream in a Japanese gold mine. Extremophiles 9:169-184

14. Inagaki $\mathrm{F}$, Takai $\mathrm{K}$, Hirayama $\mathrm{H}$, Yamato $\mathrm{Y}$, Nealson $\mathrm{KH}$, Horikoshi K (2003) Distribution and phylogenetic diversity of the subsurface microbial community in a Japanese epithermal gold mine. Extremophiles 7:307-317

15. Janssen PH (2006) Identifying the dominant soil bacterial taxa in libraries of $16 \mathrm{~S}$ rRNA and 16S rRNA genes. Appl Environ Microbiol 72:1719-1728

16. Lin LH, Wang PL, Rumble D, Lippmann-Pipke J, Boice E, Pratt LM, Sherwood Lollar B, Brodie EL, Hazen TC, Andersen GL, DeSantis TZ, Moser DP, Kershaw D, Onstott TC (2006) Longterm sustainability of a high-energy, low-diversity crustal biome. Science 20:479-482

17. Marchesi JR, Sato T, Weightman AJ, Martin TA, Fry JC, Hiom SJ, Dymock D, Wade WG (1998) Design and evaluation of useful bacterium-specific PCR primers that amplify genes coding for bacterial 16S rRNA. Appl Environ Microbiol 64:795-799

18. Martin-Laurent F, Philippot L, Hallet S, Chaussod R, Germon JC, Soulas G, Catroux G (2001) DNA extraction from soils: old bias 
for new microbial diversity analysis methods. Appl Environ Microbiol 67:2354-2359

19. McIlroy SJ, Porter K, Seviour RJ, Tillett D (2009) Extracting nucleic acids from activated sludge which reflect community population diversity. Antonie Van Leeuwenhoek 96:593-605

20. Miyazaki M, Nogi Y, Usami R, Horikoshi K (2006) Shewanella surugensis sp. nov., Shewanella kaireitica sp. nov. and Shewanella abyssi sp. nov., isolated from deep-sea sediments of Suruga Bay, Japan. Int J Syst Evol Microbiol 56:1607-1613

21. Moser DP, Onstott TC, Fredrickson JK, Brockman FJ, Balkwill DL, Drake GR, Pfiffner SM, White DC, Takai K, Pratt LM, Fong J, Sherwood Lollar B, Slater G, Phelps TJ, Spoelstra N, Deflaun M, Southam G, Welty AT, Baker BJ, Hoek J (2003) Temporal shifts in the geochemistry and microbial community structure of an ultradeep mine borehole following isolation. Geomicrobiol J 20:517-548

22. Murad E, Cashion J (2004) Mossbauer spectroscopy of environmental materials and their industrial utilization, chapter 5. Kluwer Academic Publishers, Norwell

23. Nunoura T, Hirayama H, Takami H, Oida H, Nishi S, Shimamura S, Suzuki Y, Inagaki F, Takai K, Nealson KH, Horikoshi K (2005) Genetic and functional properties of uncultivated thermophilic crenarchaeotes from a subsurface gold mine as revealed by analysis of genome fragments. Environ Microbiol 7:1967-1984

24. Onstott TC, McGown DJ, Bakermans C, Ruskeeniemi T, Ahonen L, Telling J, Soffientino B, Pfiffner SM, Sherwood-Lollar B, Frape S, Stotler R, Johnson EJ, Vishnivetskaya TA, Rothmel R, Pratt LM (2009) Microbial communities in subpermafrost saline fracture water at the lupin $\mathrm{Au}$ mine, nunavut, Canada. Microb Ecol 58:786-807

25. Onstott TC, Moser DP, Pfiffner SM, Fredrickson JK, Brockman FJ, Phelps TJ, White DC, Peacock A, Balkwill D, Hoover R, Krumholz LR, Borscik M, Kieft TL, Wilson R (2003) Indigenous and contaminant microbes in ultradeep mines. Environ Microbiol 5:1168-1191

26. Rancourt Ping (1991) Voigt-based methods for arbitrary-shape static hyperfine parameter distributions in Mossbauer spectroscopy. Nucl Instrum Methods Phys Res B 58:85-97

27. Rastogi G, Muppidi GL, Gurram RN, Adhikari A, Bischoff KM, Hughes SR, Apel WA, Bang SS, Dixon DJ, Sani RK (2009) Isolation and characterization of cellulose-degrading bacteria from the deep subsurface of the Homestake gold mine, Lead, South Dakota, USA. J Ind Microbiol Biotechnol 36:585-598

28. Rastogi G, Osman S, Vaishampayan PA, Andersen GL, Stetler LD, Sani RK (2009) Microbial diversity in uranium miningimpacted soils as revealed by high-density $16 \mathrm{~S}$ microarray and clone library. Microb Ecol 59:94-108
29. Rastogi G, Sani RK, Peyton BM, Moberly JG, Ginn TR (2009) Molecular studies on the microbial diversity associated with mining-impacted Coeur d' Alene river sediments. Microb Ecol 58:129-139

30. Rastogi G, Stetler LD, Peyton BM, Sani RK (2009) Molecular analysis of prokaryotic diversity in the deep subsurface of the former Homestake gold mine, South Dakota, USA. J Microbiol 47:371-384

31. Roane TM, Kellogg ST (1996) Characterization of bacterial communities in heavy metal contaminated soils. Can J Microbiol 42:593-603

32. Rozenson I, Bauminger EA, Heller-Kallai L (1979) Mossbauer spectra of iron in 1:1 phyllosilicates. Am Mineral 64:893-901

33. Sani RK, Peyton BM, Amonette JE, Geesey GG (2004) Reduction of uranium(VI) under sulfate reducing conditions in the presence of $\mathrm{Fe}(\mathrm{III})-($ hydr)oxides. Geochim Cosmochim Acta 68: 2639-2648

34. Sani RK, Rastogi G, Moberly JG, Dohnalkova A, Ginn TR, Spycher N, Shende N, Peyton BM (2010) The toxicity of lead to Desulfovibrio desulfuricans G20 in the presence of goethite and quartz. J Basic Microbiol 50:160-170

35. Schwertmann U, Cornell RM (1991) Iron oxides in the laboratory, preparation and characterization. VSH Publishers, New York

36. Smyth JR, Dyar MD, May HM, Bricker OP, Acker JG (1997) Crystal structure refinement and Mossbauer spectroscopy of ordered, triclinic clinochlore. Clays Clay Minerals 45:544-550

37. Southham G, Beveridge TJ (1992) Enumeration of thiobacilli within $\mathrm{pH}$-neutral and acidic mine tailings and their role in the development of secondary mineral soil. Appl Environ Microbiol 58:1904-1912

38. Takai K, Moser DP, DeFlaun M, Onstott TC, Fredrickson JK (2001) Archaeal diversity in waters from deep South African gold mines. Appl Environ Microbiol 67:5750-5760

39. von Wintzingerode F, Göbel UB, Stackebrandt E (1997) Determination of microbial diversity in environmental samples: pitfalls of PCR-based rRNA analysis. FEMS Microbiol Rev 21: 213-229

40. Wilson KH, Wilson WJ, Radosevich JL, DeSantis TZ, Viswanathan VS, Kuczmarski TA, Andersen GL (2002) High-density microarray of small-subunit ribosomal DNA probes. Appl Environ Microbiol 68:2535-2541

41. Yershova ZO, Nikitina AP, Perfileve Yu.D, Baeshkin AM (1975) Study of chamosites by gamma-resonance (Mossbauer) spectroscopy. Proc. International Clay Conference, Mexico. pp. 211-220

42. Zhou J, Bruns MA, Tiedje JM (1996) DNA recovery from soils of diverse composition. Appl Environ Microbiol 62:316-322 
Supplementary class Table 1: Bacterial and archael classes detected in the Ross and

Winze sites using PhyloChip analyses

\begin{tabular}{|c|c|c|c|}
\hline \multirow[t]{2}{*}{ Serial No. } & \multirow[t]{2}{*}{$\begin{array}{l}\text { Bacterial/archael classes } \\
\text { detected on PhyloChips }\end{array}$} & \multicolumn{2}{|c|}{$\begin{array}{l}\text { Distribution of OTUs among } \\
\text { different classes }\end{array}$} \\
\hline & & Ross site & Winze site \\
\hline 1. & Acidobacteria & 34 & 35 \\
\hline 2. & Acidobacteria-10 & 1 & 1 \\
\hline 3. & Acidobacteria-4 & 3 & 3 \\
\hline 4. & Acidobacteria-5 & 1 & 1 \\
\hline 5. & Acidobacteria-6 & 13 & 17 \\
\hline 6. & Actinobacteria & 160 & 196 \\
\hline 7. & Alphaproteobacteria ${ }^{\dagger}$ & 263 & 279 \\
\hline 8. & Anaerolineae & 21 & 19 \\
\hline 9. & Aquificae & 4 & 3 \\
\hline 10. & Bacilli & 86 & 96 \\
\hline 11. & Bacteroidetes & 21 & 29 \\
\hline 12. & BD2-10 group & 2 & 2 \\
\hline 13. & Betaproteobacteria & 125 & 134 \\
\hline 14. & $C 1 \times$ & 2 & 2 \\
\hline 15. & Catabacter & 6 & 6 \\
\hline 16. & CH21 cluster & 2 & 3 \\
\hline 17. & Chlamydiae & 2 & 2 \\
\hline 18. & Chlorobia & 3 & 3 \\
\hline 19. & Chloroflexi-3 & 2 & 2 \\
\hline 20. & Chloroflexi-4 & 2 & 2 \\
\hline 21. & Clostridia & 123 & 135 \\
\hline 22. & Cyanobacteria & 23 & 34 \\
\hline 23. & Dehalococcoidetes & 9 & 8 \\
\hline 24. & Deltaproteobacteria & 91 & 97 \\
\hline 25. & Desulfotomaculum & 4 & 6 \\
\hline 26. & Dictyoglomi & 1 & 1 \\
\hline 27. & Epsilonproteobacteria & 28 & 34 \\
\hline 28. & Flavobacteria & 29 & 21 \\
\hline 29. & Gammaproteobacteria & 218 & 255 \\
\hline 30. & gut clone group & 2 & 2 \\
\hline 31. & JS1 & 3 & $\mathrm{ND}$ \\
\hline 32. & KSAl & 1 & 1 \\
\hline 33. & Methanomicrobia $\times$ & ND & 1 \\
\hline 34. & $m g A-1$ & ND & 1 \\
\hline 35. & $m g A-2$ & 1 & 1 \\
\hline 36. & Mollicutes & 7 & 10 \\
\hline 37. & Nitrospira & 10 & 10 \\
\hline
\end{tabular}




\begin{tabular}{|c|l|r|r|}
\hline 38. & OP11-5 & 1 & 1 \\
\hline 39. & OP9 & 2 & 2 \\
\hline 40. & Planctomycetacia & 15 & 11 \\
\hline 41. & Solibacteres & 3 & 2 \\
\hline 42. & Sphingobacteria & 24 & 24 \\
\hline 43. & Spirochaetes & 2 & 35 \\
\hline 44. & Symbiobacteria & 1 & 2 \\
\hline 45. & Thermodesulfobacteria & 2 & 1 \\
\hline 46. & Thermomicrobia & 1 & 2 \\
\hline 47. & Thermoplasmatax & ND & 2 \\
\hline 48. & Thermoprotei & 1 & 1 \\
\hline 49. & Thermotogae & 2 & 1 \\
\hline 50. & TM7-3 & 113 & 2 \\
\hline 51. & Unclassified & 17 & 124 \\
\hline 52. & Verrucomicrobiae & & 16 \\
\hline
\end{tabular}

A total of 1511 and 1678 OTUs found at the Ross and Winze sites respectively were distributed in 49 and 51 classes.

${ }^{\dagger}$ Most abundant class in the Ross and Winze site.

${ }^{\mathbb{I}} \mathrm{A}$ total of 113 and 124 OTUs in the Ross and Winze sites, respectively could not be assigned to any known class and were considered unclassified.

ND- Not detected

$\times$ Class belonging to kingdom Archaea 


\section{Supplementary order Table 2}

Bacterial and archael orders detected in the Ross and Winze sites using PhyloChip analyses

\begin{tabular}{|c|c|c|c|}
\hline \multirow[t]{2}{*}{$\begin{array}{l}\text { Serial } \\
\text { No. }\end{array}$} & \multirow[t]{2}{*}{$\begin{array}{l}\text { Bacterial/archael orders detected on } \\
\text { PhyloChips }\end{array}$} & \multicolumn{2}{|c|}{$\begin{array}{c}\text { Distribution of OTUs among } \\
\text { different orders }\end{array}$} \\
\hline & & Ross site & Winze site \\
\hline 1. & Acetobacterales & 4 & 5 \\
\hline 2. & Acholeplasmatales & 1 & 3 \\
\hline 3. & Acidimicrobiales & 13 & 14 \\
\hline 4. & Acidithiobacillales & 7 & 6 \\
\hline 5. & Acidobacteriales & 34 & 34 \\
\hline 6. & acidophile isolate group & 1 & ND \\
\hline 7. & Actinomycetales $\dagger$ & 132 & 162 \\
\hline 8. & Aeromonadales & 3 & 2 \\
\hline 9. & Alteromonadales & 27 & 32 \\
\hline 10. & AMD clone group & 5 & 5 \\
\hline 11. & Anaeroplasmatales & 4 & 4 \\
\hline 12. & aquatic clone group & 3 & 3 \\
\hline 13. & Aquificales & 4 & 3 \\
\hline 14. & Azospirillales & 7 & 7 \\
\hline 15. & Bacillales & 67 & 68 \\
\hline 16. & Bacteroidales & 21 & 29 \\
\hline 17. & Bdellovibrionales & 2 & 2 \\
\hline 18. & Bifidobacteriales & 1 & 7 \\
\hline 19. & Bradyrhizobiales & 49 & 58 \\
\hline 20. & Burkholderiales & 74 & 84 \\
\hline 21. & Clax & ND & 1 \\
\hline 22. & $C 1 b \times$ & 1 & $\mathrm{ND}$ \\
\hline 23. & Caldithrales & 2 & 2 \\
\hline 24. & Campylobacterales & 28 & 34 \\
\hline 25. & Caulobacterales & 11 & 10 \\
\hline 26. & Chlamydiales & 2 & 2 \\
\hline 27. & Chlorobiales & 3 & 3 \\
\hline 28. & Chloroflexi-1a & 6 & 7 \\
\hline 29. & Chloroflexi-1b & 2 & 2 \\
\hline 30. & Chloroflexi-1f & 2 & 2 \\
\hline 31. & Chloroplasts & 16 & 17 \\
\hline 32. & Chromatiales & 19 & 24 \\
\hline 33. & Chroococcales & 1 & 1 \\
\hline 34. & Clostridiales & 121 & 132 \\
\hline 35. & Consistiales & 8 & 7 \\
\hline 36. & Coriobacteriales & 2 & 2 \\
\hline
\end{tabular}




\begin{tabular}{|c|c|c|c|}
\hline 37. & dechlorinating clone group & 1 & 1 \\
\hline 38. & Desulfobacterales & 25 & 25 \\
\hline 39. & Desulfovibrionales & 11 & 13 \\
\hline 40. & Desulfurococcales $\times$ & ND & 1 \\
\hline 41. & Desulfuromonadales & 6 & 5 \\
\hline 42. & Devosia & ND & 1 \\
\hline 43. & Dictyoglomales & 1 & 1 \\
\hline 44. & EB1021 group & 4 & 4 \\
\hline 45. & Ellin307/WD2124 & 2 & 2 \\
\hline 46. & Ellin314/wr0007 & 5 & 7 \\
\hline 47. & Ellin329/Riz1046 & 3 & 3 \\
\hline 48. & Ellin6075/11-25 & 2 & 2 \\
\hline 49. & Ellin6095/SC-I-39 & 2 & 2 \\
\hline 50. & Enterobacteriales & 21 & 46 \\
\hline 51. & Flavobacteriales & 29 & 21 \\
\hline 52. & GAO cluster & 4 & 4 \\
\hline 53. & Holophagales & ND & 1 \\
\hline 54. & Hydrogenophilales & 2 & 2 \\
\hline 55. & Lactobacillales & 19 & 28 \\
\hline 56. & Legionellales & 12 & 11 \\
\hline 57. & Methanosarcinales $\times$ & ND & 1 \\
\hline 58. & Methylococcales & 7 & 9 \\
\hline 59. & Methylophilales & 1 & 1 \\
\hline 60. & MND1 clone group & 4 & 4 \\
\hline 61. & Mycoplasmatales & 1 & 2 \\
\hline 62. & Myxococcales & 16 & 15 \\
\hline 63. & Neisseriales & 6 & 6 \\
\hline 64. & Nitrosomonadales & 13 & 15 \\
\hline 65. & Nitrospirales & 10 & 10 \\
\hline 66. & Nostocales & 1 & 6 \\
\hline 67. & Oceanospirillales & 8 & 13 \\
\hline 68. & Oscillatoriales & 1 & 3 \\
\hline 69. & Pasteurellales & 2 & 2 \\
\hline 70. & Planctomycetales & 14 & 11 \\
\hline 71. & Plectonema & 3 & 3 \\
\hline 72. & Prochlorales & ND & 1 \\
\hline 73. & Pseudanabaena & ND & 1 \\
\hline 74. & Pseudomonadales & 38 & 37 \\
\hline 75. & Rhizobiales & 60 & 66 \\
\hline 76. & Rhodobacterales & 55 & 39 \\
\hline 77. & Rhodocyclales & 16 & 13 \\
\hline 78. & Rickettsiales & 9 & 10 \\
\hline 79. & Roseiflexales & 2 & 2 \\
\hline 80. & Rubrobacterales & 6 & 5 \\
\hline 81. & SAR86 & 1 & 1 \\
\hline
\end{tabular}




\begin{tabular}{|r|l|r|r|}
\hline 82. & Scytonema & $\mathrm{ND}$ & 1 \\
\hline 83. & Sphingobacteriales & 24 & 24 \\
\hline 84. & Sphingomonadales & 24 & 38 \\
\hline 85. & Spirochaetales & 24 & 35 \\
\hline 86. & Spirulina & 3 & 1 \\
\hline 87. & SUP05 & 2 & 3 \\
\hline 88. & Symbiobacterales & 4 & 2 \\
\hline 89. & Symbionts & 12 & 5 \\
\hline 90. & Syntrophobacterales & 1 & 14 \\
\hline 91. & Thermodesulfobacteriales & 1 & 1 \\
\hline 92. & Thermotogales & 13 & 1 \\
\hline 93. & Thiotrichales & 264 & 9 \\
\hline 94. & Unclassified & 2 & 282 \\
\hline 95. & uranium waste clones & 2 & 2 \\
\hline 96. & Verorhodospirilla & 17 & 1 \\
\hline 97. & Verrucomicrobiales & $\mathrm{ND}$ & 16 \\
\hline 98. & Vibrionales & 1 & 3 \\
\hline 99. & WPS-1 & 10 & $\mathrm{ND}$ \\
\hline 100. & Xanthomonadales & 10 \\
\hline
\end{tabular}

A total of 1511 and 1678 OTUs found at the Ross and Winze sites respectively were distributed in 91 and 97 orders.

${ }^{\dagger}$ Most abundant order in the Ross and Winze site.

II A total of 264 and 282 OTUs in the Ross and Winze sites, respectively could not be assigned to any known order and were considered unclassified.

$\times$ Order belonging to kingdom Archaea

ND- Not detected 


\section{Supplementary family Table 3}

Bacterial and archael families detected in the Ross and Winze sites using PhyloChip analyses

\begin{tabular}{|c|c|c|c|}
\hline \multirow[t]{2}{*}{ Serial No. } & \multirow[t]{2}{*}{$\begin{array}{l}\text { Bacterial/Archael families } \\
\text { detected on the PhyloChips }\end{array}$} & \multicolumn{2}{|c|}{$\begin{array}{l}\text { Distribution of OTUs among } \\
\text { different families }\end{array}$} \\
\hline & & Ross site & Winze site \\
\hline 1. & Acetobacteraceae & 2 & 2 \\
\hline 2. & Acholeplasmataceae & 1 & 3 \\
\hline 3. & Acidimicrobiaceae & 8 & 9 \\
\hline 4. & Acidithiobacillaceae & 7 & 6 \\
\hline 5. & Acidobacteriaceae & 34 & 34 \\
\hline 6. & Acidothermaceae & 1 & 1 \\
\hline 7. & Actinomycetaceae & 2 & 3 \\
\hline 8. & Aerococcaceae & 2 & 3 \\
\hline 9. & Aeromonadaceae & 2 & 2 \\
\hline 10. & Alcaligenaceae & 6 & 5 \\
\hline 11. & Alcanivoraceae & 1 & 4 \\
\hline 12. & Alicyclobacillaceae & 1 & 1 \\
\hline 13. & Alteromonadaceae & 22 & 29 \\
\hline 14. & Anammoxales & 4 & 4 \\
\hline 15. & Anaplasmataceae & 5 & 5 \\
\hline 16. & Azospirillaceae & 4 & 4 \\
\hline 17. & Bacillaceae & 49 & 47 \\
\hline 18. & Bacteroidaceae & 1 & 3 \\
\hline 19. & Bartonellaceae & 4 & 4 \\
\hline 20. & Bdellovibrionaceae & 1 & 1 \\
\hline 21. & Beijerinck/Rhodoplan/Methylocyst & 14 & 19 \\
\hline 22. & Bifidobacteriaceae & 1 & 7 \\
\hline 23. & Blattabacteriaceae & 1 & 1 \\
\hline 24. & Bradyrhizobiaceae & 24 & 26 \\
\hline 25. & Brevibacteriaceae & 1 & 1 \\
\hline 26. & Brucellaceae & 2 & 2 \\
\hline 27. & Burkholderiaceae & 8 & 7 \\
\hline 28. & Caedibacteraceae & 3 & 3 \\
\hline 29. & Caldithraceae & 2 & 2 \\
\hline 30. & Campylobacteraceae & 4 & 5 \\
\hline 31. & Caryophanaceae & 1 & 1 \\
\hline 32. & Caulobacteraceae & 11 & 10 \\
\hline 33. & Cellulomonadaceae & 6 & 7 \\
\hline 34. & Chlamydiaceae & 1 & 1 \\
\hline 35. & Chlorobiaceae & 3 & 3 \\
\hline 36. & Chloroplasts & 16 & 17 \\
\hline 37. & Chromatiaceae & 9 & 9 \\
\hline
\end{tabular}




\begin{tabular}{|c|c|c|c|}
\hline 38. & Clostridiaceae & 41 & 51 \\
\hline 39. & Comamonadaceae $^{\mathrm{b}}$ & 45 & 54 \\
\hline 40. & Coriobacteriaceae & 2 & 2 \\
\hline 41. & Corynebacteriaceae & 7 & 7 \\
\hline 42. & Coxiellaceae & 6 & 6 \\
\hline 43. & Crenotrichaceae & 4 & 5 \\
\hline 44. & Cryomorphaceae & $\mathrm{ND}$ & 1 \\
\hline 45. & Dermabacteraceae & 1 & 3 \\
\hline 46. & Dermatophilaceae & 1 & 1 \\
\hline 47. & Desulfoarculaceae & 1 & 1 \\
\hline 48. & Desulfobacteraceae & 12 & 12 \\
\hline 49. & Desulfobulbaceae & 8 & 8 \\
\hline 50. & Desulfohalobiaceae & 1 & 1 \\
\hline 51. & Desulfomicrobiaceae & 2 & 2 \\
\hline 52. & Desulfovibrionaceae & 7 & 9 \\
\hline 53. & Desulfurococcaceaex & ND & 1 \\
\hline 54. & Desulfuromonaceae & 2 & 2 \\
\hline 55. & Dictyoglomaceae & 1 & 1 \\
\hline 56. & Dietziaceae & $\mathrm{ND}$ & 2 \\
\hline 57. & Ectothiorhodospiraceae & 7 & 8 \\
\hline 58. & Enterobacteriaceae & 21 & 45 \\
\hline 59. & Enterococcaceae & 6 & 7 \\
\hline 60. & Erysipelotrichaceae & 4 & 4 \\
\hline 61. & Eubacteriaceae & 1 & 1 \\
\hline 62. & Flammeovirgaceae & 1 & 1 \\
\hline 63. & Flavobacteriaceae & 27 & 18 \\
\hline 64. & Flexibacteraceae & 12 & 11 \\
\hline 65. & Francisellaceae & 1 & 1 \\
\hline 66. & Frankiaceae & 1 & 2 \\
\hline 67. & Geobacteraceae & 3 & 2 \\
\hline 68. & Gordoniaceae & 3 & 5 \\
\hline 69. & Halobacillaceae & 3 & 4 \\
\hline 70. & Halomonadaceae & 3 & 4 \\
\hline 71. & Halothiobacillaceae & 1 & 5 \\
\hline 72. & Helicobacteraceae & 23 & 23 \\
\hline 73. & Hydrogenophilaceae & 2 & 2 \\
\hline 74. & Hydrogenothermaceae & 2 & 2 \\
\hline 75. & Hyphomicrobiaceae & 13 & 14 \\
\hline 76. & Hyphomonadaceae & 1 & 1 \\
\hline 77. & Kineosporiaceae & 3 & 4 \\
\hline 78. & Lachnospiraceae & 39 & 39 \\
\hline 79. & Lactobacillaceae & 4 & 10 \\
\hline 80. & Legionellaceae & 4 & 3 \\
\hline 81. & Leptospiraceae & ND & 2 \\
\hline 82. & Magnetospirillaceae & 1 & 1 \\
\hline
\end{tabular}




\begin{tabular}{|c|c|c|c|}
\hline 83. & Methanosarcinaceae & ND & 1 \\
\hline 84. & Methylobacteriaceae & 2 & 3 \\
\hline 85. & Methylococcaceae & 6 & 8 \\
\hline 86. & Methylophilaceae & 1 & 1 \\
\hline 87. & Microbacteriaceae & 12 & 14 \\
\hline 88. & Micrococcaceae & 11 & 12 \\
\hline 89. & Micromonosporaceae & 13 & 15 \\
\hline 90. & Microthrixineae & 1 & 1 \\
\hline 91. & Moraxellaceae & 8 & 8 \\
\hline 92. & Mycobacteriaceae & 17 & 19 \\
\hline 93. & Mycoplasmataceae & 1 & 2 \\
\hline 94. & Myхососсасеае & ND & 5 \\
\hline 95. & Neisseriaceae & 5 & 15 \\
\hline 96. & Nitrosomonadaceae & 13 & 1 \\
\hline 97. & Nitrospinaceae & 1 & 10 \\
\hline 98. & Nitrospiraceae & 10 & 15 \\
\hline 99. & Nocardiaceae & 9 & 3 \\
\hline 100. & Nocardioidaceae & 1 & 2 \\
\hline 101. & Oceanospirillaceae & 1 & 2 \\
\hline 102. & Oxalobacteraceae & 10 & 12 \\
\hline 103. & Paenibacillaceae & 6 & 6 \\
\hline 104. & Parachlamydiaceae & 1 & 1 \\
\hline 105. & Pasteurellaceae & 2 & 2 \\
\hline 106. & Peptococc/Acidaminococc & 11 & 11 \\
\hline 107. & Peptostreptococcaceae & 21 & 23 \\
\hline 108. & Phyllobacteriaceae & 10 & 11 \\
\hline 109. & Pirellulae & 8 & 5 \\
\hline 110. & Piscirickettsiaceae & 4 & 3 \\
\hline 111. & Planctomycetaceae & 2 & 2 \\
\hline 112. & Polyangiaceae & 15 & 14 \\
\hline 113. & Porphyromonadaceae & 1 & 5 \\
\hline 114. & Prevotellaceae & 1 & 2 \\
\hline 115. & Promicromonosporaceae & 2 & 2 \\
\hline 116. & Pseudoalteromonadaceae & 2 & 2 \\
\hline 117. & Pseudomonadaceae & 30 & 29 \\
\hline 118. & Pseudonocardiaceae & 10 & 6 \\
\hline 119. & Ralstoniaceae & 4 & 4 \\
\hline 120. & Rhizobiaceae & 16 & 18 \\
\hline 121. & Rhodobacteraceae ${ }^{\mathrm{a}}$ & 53 & 35 \\
\hline 122. & Rhodobiaceae & 1 & 1 \\
\hline 123. & Rhodocyclaceae & 16 & 13 \\
\hline 124. & Rickettsiaceae & 2 & 3 \\
\hline 125. & Rikenellaceae & 1 & 1 \\
\hline 126. & Roseococcaceae & 1 & 1 \\
\hline 127. & Rubrobacteraceae & 6 & 5 \\
\hline
\end{tabular}




\begin{tabular}{|c|c|c|c|}
\hline 128. & Saccharospirillaceae & 1 & 1 \\
\hline 129. & SAR11 & 1 & ND \\
\hline 130. & Shewanellaceae & 1 & 1 \\
\hline 131. & Sphingobacteriaceae & 4 & 4 \\
\hline 132. & Sphingomonadaceae & 24 & 37 \\
\hline 133. & Spirochaetaceae & 24 & 33 \\
\hline 134. & Sporichthyaceae & ND & 2 \\
\hline 135. & Sporolactobacillaceae & 1 & 2 \\
\hline 136. & Staphylococcaceae & 3 & 4 \\
\hline 137. & Streptococcaceae & 7 & 8 \\
\hline 138. & Streptomycetaceae & 14 & 15 \\
\hline 139. & Streptosporangiaceae & 2 & 4 \\
\hline 140. & Succinivibrionaceae & 1 & $\mathrm{ND}$ \\
\hline 141. & Syntrophaceae & 3 & 5 \\
\hline 142. & Syntrophobacteraceae & 9 & 9 \\
\hline 143. & Syntrophomonadaceae & 4 & 4 \\
\hline 144. & Thermoactinomycetaceae & 1 & 2 \\
\hline 145. & Thermodesulfobacteriaceae & 1 & 1 \\
\hline 146. & Thermomonosporaceae & 2 & 1 \\
\hline 147. & Thermotogaceae & 1 & 1 \\
\hline 148. & Thiotrichaceae & 8 & 5 \\
\hline 149. & Unclassified $^{\text {II }}$ & 434 & 477 \\
\hline 150. & Verrucomicrobia subdivision 3 & 2 & ND \\
\hline 151. & Verrucomicrobia subdivision 5 & 3 & 4 \\
\hline 152. & Verrucomicrobia subdivision 7 & 3 & 3 \\
\hline 153. & Verrucomicrobiaceae & 5 & 5 \\
\hline 154. & Vibrionaceae & ND & 3 \\
\hline 155. & Xanthobacteraceae & 2 & 3 \\
\hline 156. & Xanthomonadaceae & 10 & 10 \\
\hline 157. & Xiphinematobacteraceae & 1 & 1 \\
\hline
\end{tabular}

A total of 1511 and 1678 OTUs found at the Ross and Winze sites respectively were distributed in 149 and 154 families.

${ }^{\mathbb{A}} \mathrm{A}$ total of 434 and 477 OTUs in the Ross and Winze sites, respectively could not be assigned to any known family and were considered unclassified.

${ }^{a}$ Most abundant family in the Ross site.

${ }^{\mathrm{b}}$ Most abundant family in the Winze site.

$\times$ Families belonging to kingdom Archaea.

ND-not detected 
Supp. Genera Table 4: Bacterial and Archael genera retrieved on PhyloChips from Ross

and Winze sites

\begin{tabular}{|c|c|c|}
\hline Representative organisms of the OTUs detected on PhyloChips & Ross site & Winze site \\
\hline Methanosarcina baltica str. GSI & - & + \\
\hline hydrothermal vent clone VC2.1 Arc13 & - & - \\
\hline hot spring clone SUBT-14 & + & + \\
\hline hydrothermal vent clone pIVWA1I & - & + \\
\hline soil clone SCA11 & + & - \\
\hline hot spring clone env.OPS7 & + & + \\
\hline Sulfurihydrogenibium azorense & + & + \\
\hline Coprothermobacter sp. str. Dex80-3 & + & + \\
\hline Thermosipho sp. str. MV1063 & + & + \\
\hline Geothermobacterium ferrireducens & + & + \\
\hline Antarctic cryptoendolith clone FBP471 & + & + \\
\hline sludge clone SBR2022 & + & + \\
\hline Green non-sulfur isolate str. B1-5 & + & + \\
\hline forest soil clone DUNssu055 (-2B) (OTU\#087) & + & + \\
\hline DCP-dechlorinating consortium clone SHA-21 & + & + \\
\hline anaerobic bioreactor clone $S H D-71$ & + & + \\
\hline hydrothermal vent polychaete mucous clone P. palm C 37 & + & + \\
\hline Thermus sp. str. C4 & + & + \\
\hline Vulcanithermus mediatlanticus str. TR & + & + \\
\hline hypersaline pond clone $L A 7-B 27 N$ & + & + \\
\hline geothermal clone $\mathrm{STO1-SN3H}$ & + & + \\
\hline forested wetland clone FW68 & + & + \\
\hline sludge clone SBRA136 & + & + \\
\hline sludge clone SBR1039 & - & + \\
\hline 4MB-degrading consortium clone UASB_TL26 & + & + \\
\hline uranium mining waste pile clone JG37-AG-131 sp. & + & + \\
\hline Great Artesian Basin clone G19 & + & + \\
\hline lab-scale sludge clone SBR1108 & + & - \\
\hline uranium tailings soil clone Sh765B-AG-45 & + & + \\
\hline uranium mining waste clone JG34-KF-252 & + & + \\
\hline acid mine drainage clone BA29 & - & + \\
\hline forested wetland clone FW114 & + & + \\
\hline mercury and PCB contaminated saltmarsh sediment clone LCP-6 LCP-6 & + & + \\
\hline forested wetland clone FW19 & + & + \\
\hline forested wetland clone FW5 & + & + \\
\hline $\begin{array}{l}\text { ground water deep-well injection disposal site radioactive wastes Tomsk-7 clone } \\
\text { S15A-MN30 bacterium }\end{array}$ & + & + \\
\hline forested wetland clone FW118 & + & + \\
\hline Elbe river clone DEV055 & + & + \\
\hline anoxic marine sediment clone LDI-PA34 & + & + \\
\hline Elbe river clone DEV045 & + & + \\
\hline anoxic marine sediment clone LD1-PB2O & + & + \\
\hline anoxic marine sediment clone LDI-PB12 & + & + \\
\hline
\end{tabular}




\begin{tabular}{|c|c|c|}
\hline anoxic marine sediment clone LDI-PBI & + & + \\
\hline anoxic marine sediment clone LD1-PA2O & + & + \\
\hline anoxic marine sediment clone LDI-PA50 & - & + \\
\hline Guaymas Basin hydrothermal sediment clone a $2 b 018$ & + & + \\
\hline Mono lake clone ML316M-1 & + & + \\
\hline Fucophilus fucoidanolyticus str. SI-1234 & + & + \\
\hline coal effluent wetland clone RCP2-6 & + & + \\
\hline Opitutus sp. str. SA-9 & + & + \\
\hline sludge clone $\mathrm{H} 2$ & + & + \\
\hline forested wetland clone FW49 & + & - \\
\hline coal effluent wetland clone FW4 & + & - \\
\hline Akkermansia muciniphila & + & + \\
\hline hydrothermal vent polychaete mucous clone P. palm C 85 & + & + \\
\hline Candidatus Xiphinematobacter brevicolli & + & + \\
\hline termite gut homogenate clone Rs-P07 bacterium & + & + \\
\hline termite gut homogenate clone Rs-D89 & + & + \\
\hline$U A S B$ reactor granular sludge clone $P D-U A S B-13 G+C$ & + & + \\
\hline Flexistipes sp. str. E3_33 & + & + \\
\hline terephthalate-degrading consortium clone TA19 & + & + \\
\hline uranium mining waste pile soil sample clone JG30-KF-CM45 & + & + \\
\hline Synergistes sp. $P 1$ str. $P 4 G_{-} 18$ & + & + \\
\hline hot spring clone OPB72 & + & + \\
\hline DCP-dechlorinating consortium clone SHA-1 & + & + \\
\hline polluted aquifer clone BVC56 & + & + \\
\hline CB-contaminated groundwater clone GOUTB15 & + & + \\
\hline uranium mining mill tailing clone GR-296.II.52 GR-296.I.52 & + & + \\
\hline fjord ikaite column clone un-c23 & + & + \\
\hline Ferribacter thermoautotrophicus & + & + \\
\hline penguin droppings sediments clone KDI-1 & + & + \\
\hline hot spring clone $O P B 25$ & + & + \\
\hline soil clone PBS-25 & + & + \\
\hline termite gut homogenate clone Rs-D43 group & + & + \\
\hline thermal spring mat clone O1aA90 & + & + \\
\hline Guaymas Basin hydrothermal sediment clone a2b010 & + & + \\
\hline DCP-dechlorinating consortium clone SHA-124 & + & - \\
\hline termite gut homogenate clone Rs-H93 group & + & + \\
\hline termite gut homogenate clone $R s-D 95$ group & - & + \\
\hline marine sediment above hydrate ridge clone Hyd24-44 sp. & + & + \\
\hline forest soil clone $\mathrm{S} 0134$ & + & + \\
\hline marine sediment clone Sva0515 & + & + \\
\hline uranium mining waste pile clone JG37-AG-81 sp. & + & + \\
\hline uranium mining waste pile clone JG34-KF-153 & + & + \\
\hline forested wetland clone FW144 & + & + \\
\hline uranium mill tailings soil sample clone GuBH2-AG-47 sp. & + & + \\
\hline marine sediment above hydrate ridge clone Hyd $24-32$ & + & + \\
\hline uranium mining waste pile clone JG37-AG-36 & + & + \\
\hline uranium mill tailings soil sample clone GuBH2-AD-9 sp. & + & + \\
\hline trichloroethene-contaminated site clone FTLM205 proteobacterium & + & + \\
\hline
\end{tabular}




\begin{tabular}{|c|c|c|}
\hline trichloroethene-contaminated site clone FTLM5 bacterium & - & + \\
\hline rumen clone $B S 5$ & + & + \\
\hline anaerobic VC-degrading enrichment clone VC47 bacterium & + & + \\
\hline soil metagenomic library clone $17 F 9$ & + & + \\
\hline activated sludge clone 2951 & + & + \\
\hline soil clone RB27 & - & + \\
\hline Mammoth cave clone CCM15a & + & + \\
\hline soil clone $23 k 22$ & - & + \\
\hline soil clone $576-2$ & - & + \\
\hline Holophaga/Acidobacterium phylum clone iiil-15 & + & + \\
\hline bioreactor clone mle1-25 & + & + \\
\hline Mammoth cave clone CCM8b & + & + \\
\hline benzoate-degrading consortium clone BA059 & + & + \\
\hline $\begin{array}{l}\text { soil sample uranium mining waste pile near town Johanngeorgenstadt clone } \\
\text { JG36-TzT-10 }\end{array}$ & + & + \\
\hline uranium mining waste pile clone JG34-KF-27 & + & + \\
\hline soil clone $\mathrm{Cl12}$ & + & + \\
\hline $\begin{array}{l}\text { soil sample uranium mining waste pile near town Johanngeorgenstadt clone } \\
\text { JG36-TzT-202 bacterium }\end{array}$ & + & + \\
\hline uranium mining waste pile clone JG37-AG-112 sp. & + & + \\
\hline uranium mining waste pile clone JG37-AG-29 sp. & + & + \\
\hline uranium mining waste pile clone JG37-AG-73 sp. & + & + \\
\hline soil clone BAC-14A1 & + & + \\
\hline soil clone DAO23 & + & + \\
\hline soil clone RB24 & + & + \\
\hline uranium mill tailings soil sample clone $G u B H 2-A D-16 s p$. & + & + \\
\hline Holophaga/Acidobacterium phylum clone ii3-12 & - & + \\
\hline heavy metal-contaminated soil clone a13114 & + & + \\
\hline Holophaga/Acidobacterium phylum clone $32-10$ & + & + \\
\hline uranium mining waste pile clone JG34-KF-135 & + & + \\
\hline uranium mining waste pile clone JG37-AG-31 sp. & + & + \\
\hline uranium mining waste pile clone JG37-AG-145 sp. & + & + \\
\hline $\begin{array}{l}\text { soil sample uranium mining waste pile near town Johanngeorgenstadt clone } \\
\text { JG36-TzT-200 bacterium }\end{array}$ & + & + \\
\hline uranium mining waste pile clone JG37-AG-117 sp. & + & + \\
\hline termite gut homogenate clone Rs-D38 bacterium & - & + \\
\hline termite gut homogenate clone Rs-D44 bacterium & + & + \\
\hline trichloroethene-contaminated site clone FTLpost 3 bacterium & + & + \\
\hline Mono Lake at depth 35 m station 6 July 2000 clone ML635J-40 bacterium & + & + \\
\hline SHA-25 clone & + & + \\
\hline marine sediment above hydrate ridge clone Hyd-B2-1 bacterium & + & + \\
\hline marine? clone KD3-17 & + & + \\
\hline Mono Lake at depth 35 m station 6 July 2000 clone ML635J-15 bacterium & + & + \\
\hline DCP-dechlorinating consortium clone SHA-94 & - & + \\
\hline hydrothermal vent polychaete mucous clone P. palm A 53 & + & + \\
\hline penguin droppings sediments clone KD1-125 & + & + \\
\hline anoxic bulk soil flooded rice microcosm clone BSV73 & + & + \\
\hline chlorobenzene-degrading consortium clone IIIB-1 & + & + \\
\hline corneal ulcer clone E1-K9 & + & + \\
\hline
\end{tabular}




\begin{tabular}{|c|c|c|}
\hline swine intestine clone p-987-s962-5 & - & + \\
\hline Bacteroides distasonis & - & + \\
\hline Dysgonomonas wimpennyi str. ANFA2 & + & + \\
\hline sphagnum peat bog clone $26-4 b 2$ & - & + \\
\hline mouse feces clone L11-6 & - & + \\
\hline cow rumen clone BF24 & + & + \\
\hline cow rumen clone BE14 & - & + \\
\hline rumen clone F24-B03 & + & + \\
\hline mouse feces clone F8 & - & + \\
\hline Crocinitomix catalasitica str. IFO 15977 & - & + \\
\hline Blattabacterium species & + & + \\
\hline Delaware River estuary clone $1 G 12$ & + & + \\
\hline patient's bronchoalveolar lavage isolate str. MDA2507 sp. & + & - \\
\hline Flavobacterium frigoris str. LMG 21471 & + & + \\
\hline Arctic sea ice ARK10159 & + & + \\
\hline $\begin{array}{l}\text { ground water deep-well injection disposal site radioactive wastes Tomsk-7 clone } \\
\text { S15A-MN27 bacterium }\end{array}$ & + & + \\
\hline Flavobacterium hibernum str. ATCC51468 & + & - \\
\hline Flavobacterium aquatile & + & + \\
\hline Tenacibaculum maritimum str. IFO 15946 & + & + \\
\hline marine sediment above hydrate ridge clone Hyd24-41 bacterium & + & - \\
\hline Tenacibaculum ovolyticum str. IAM14318 & + & + \\
\hline Riftia pachyptila's tube clone R103-B20 & + & + \\
\hline Capnocytophaga sp. str. ChDC OS43 & + & - \\
\hline Cytophaga sp. I-545 & + & + \\
\hline Aequorivita antarctica str. QSSC9-14 & + & - \\
\hline Bacteroidetes Ko706 & - & + \\
\hline Cytophaga sp. str. MBIC04693 & + & - \\
\hline Flavobacterium sp. str. V4.MS.29=MM_2747 & + & + \\
\hline Cytophaga uliginosa & + & + \\
\hline Arctic sea ice ARK10004 & - & + \\
\hline bacterioplankton clone $A E G E A N \_179$ & + & - \\
\hline marine bacterioplankton clone MB11E04 & + & - \\
\hline Psychroserpens burtonensis str. S2-64 & + & - \\
\hline acidic forest soil clone UCl & + & + \\
\hline marine? clone KD3-67 & + & + \\
\hline DCP-dechlorinating consortium clone SHA-5 & + & + \\
\hline marine sediment above hydrate ridge clone Hyd89-72 bacterium & + & + \\
\hline fruiting body Pleurotus eryngii clone PEO1 & + & + \\
\hline Mono Lake at depth 35 m station 6 July 2000 clone ML635J-56 & + & + \\
\hline hydrothermal vent polychaete mисоus clone P. palm C/A 20 & + & + \\
\hline temperate estuarine mud clone KM02 & + & + \\
\hline Pedobacter sp. An13 & - & + \\
\hline crevicular epithelial cells clone AZ123 & + & + \\
\hline activated sludge foam clone 47 & + & + \\
\hline Sphingobacteriaceae str. Ellin160 & + & + \\
\hline municipal wastewater treatment bioreactor isolate str. CAGY10 & + & + \\
\hline Toolik Lake main station at $3 \mathrm{~m}$ depth clone TLM11/TLMdgge04 & + & + \\
\hline Sphingobacterium heparinum & + & - \\
\hline
\end{tabular}




\begin{tabular}{|c|c|c|}
\hline Flexibacter sancti str. IFO 16034 & - & + \\
\hline Austria: Lake Gossenkoellesee clone GKS2-106 GKS2-106 & + & - \\
\hline anaerobic VC-degrading enrichment clone VClO bacterium & - & + \\
\hline Flexibacter japonensis str. IFO 16041 & + & + \\
\hline Cilia- respiratory isolate str. $243-54$ & + & + \\
\hline Haliscomenobacter hydrossis & + & + \\
\hline Cytophaga sp. I-1787 & + & + \\
\hline CFB group clone ML615J-4 & + & + \\
\hline Microscilla arenaria str. IFO 15982 & + & + \\
\hline Cyclobacterium marinum str. DSM 745 & + & - \\
\hline Hongiella mannitolivorans str. IMSNU 14012 JC2050 & + & + \\
\hline penguin droppings sediments clone KD6-118 & + & + \\
\hline Hymenobacter group clone KL-59-7-9 & - & + \\
\hline Hymenobacter sp. str. NS/50 & + & - \\
\hline Flexibacter flexilis subsp. pelliculosus str. IFO 16028 subsp. & + & + \\
\hline Arctic sea ice cryoconite clone ARKCRY-50 & + & + \\
\hline EBPR sludge lab scale clone HP1A92 & - & + \\
\hline travertine hot spring clone SMIC04 & + & + \\
\hline Flexibacter roseolus str. IFO 16030 & + & + \\
\hline Saltmarsh mиd clone $K-790$ & + & + \\
\hline Mammoth cave clone CCM9b & + & + \\
\hline hydrothermal vent polychaete mucous clone P. palm A 12 & + & + \\
\hline DCP-dechlorinating consortium clone SHA-83 & + & + \\
\hline sludge clone A12b & + & + \\
\hline Chlorobium ferrooxidans DSM 13031 str. KofoX & + & + \\
\hline sewage sludge clone & - & + \\
\hline benzene-degrading nitrate-reducing consortium clone Cart-N3 bacterium & + & + \\
\hline Chlorobium phaeovibrioides str. 2631 & + & + \\
\hline Chlorobium limicola str. $\mathrm{MI}$ & + & + \\
\hline Caldilinea aerophila & + & - \\
\hline DCP-dechlorinating consortium clone SHD-231 & + & + \\
\hline mixed genomic activated sludge clone SBR2037 & + & + \\
\hline uranium mining waste pile clone JG34-KF-221 & + & + \\
\hline DCP-dechlorinating consortium clone SHA-27 & + & + \\
\hline benzene-contaminated groundwater clone ZZ14AC19 & + & + \\
\hline forest soil clone C043 & + & + \\
\hline thermophilic UASB granular sludge isolate str. IMO-1 bacterium & - & + \\
\hline DCP-dechlorinating consortium clone SHA-36 & + & + \\
\hline anaerobic bioreactor clone $S H D-238$ & + & + \\
\hline $\begin{array}{l}\text { sediments collected at Charon's Cascade near Echo River October } 2000 \text { clone } \\
\text { CCD21 }\end{array}$ & + & + \\
\hline forest soil clone S0208 & + & + \\
\hline DCP-dechlorinating consortium clone SHA-8 & + & + \\
\hline DCP-dechlorinating consortium clone SHA-147 & + & + \\
\hline travertine hot spring clone SM1D10 & + & + \\
\hline DCP-dechlorinating consortium clone SHA-2 & + & + \\
\hline temperate estuarine mud clone KM87 & + & + \\
\hline aerobic basin clone CYOARA032A03 & + & + \\
\hline anoxic basin clone CY0ARA028B09 & + & + \\
\hline
\end{tabular}




\begin{tabular}{|c|c|c|}
\hline aerobic basin clone CYOARA026G04 & + & + \\
\hline USA: Colorado Fort collins Horsetooth Reservoir clone HT2F11 & + & + \\
\hline aerobic basin clone CY0ARA025E11 & + & + \\
\hline anoxic marine sediment clone LD1-PA40 & + & - \\
\hline anaerobic digester clone CYOARA03OF07 & + & - \\
\hline Pirellula sp. str. ACM 3181 & + & + \\
\hline anoxic basin clone CY0ARA027E04 & + & - \\
\hline DCP-dechlorinating consortium clone SHA-43 & + & - \\
\hline anoxic basin clone CYOARA028C04 & + & + \\
\hline anoxic basin clone CY0ARA027D01 & + & + \\
\hline Crater Lake clone CL500-15 & + & + \\
\hline neutral pH mine biofilm clone $44 a-B 1-34$ & + & + \\
\hline Chlamydophila pneumoniae str. AR39 & + & + \\
\hline Rumen isolate str. YS2 & - & + \\
\hline termite gut homogenate clone Rs-H34 & + & + \\
\hline Arthrospira platensis str. IAM M-135 & - & + \\
\hline Oscillatoria sancta str. PCC 7515 & + & + \\
\hline Lyngbya aestuarii str. PCC 7419 & - & + \\
\hline Anabaena augstumalis 'SCHMIDKE JAHNKE/4a' str. SCMIDKE JAHNKE/4a & - & + \\
\hline Chlorogloeopsis fritschii str. PCC 6912 & + & + \\
\hline Hapalosiphon welwitschii & + & + \\
\hline Anabaena circinalis str. AWQC150A & - & + \\
\hline Nodularia sphaerocarpa str. UTEX B 2093 & + & + \\
\hline Nodularia spumigena str. PCC73104 & - & + \\
\hline Scytonema sp. str. IAM M-262 & - & + \\
\hline Cyanospira rippkae str. PCC 9501 & - & + \\
\hline Anabaena variabilis str. IAM M-204 & - & + \\
\hline Spirulina subsalsa str. FACHB351 & + & + \\
\hline $\begin{array}{l}\text { silica sinter depositing geothermal power station discharge drain clone ST01- } \\
\text { SN2C }\end{array}$ & + & + \\
\hline Synechococcus sp. str. UH7 & + & + \\
\hline Acaryochloris marina str. MBIC11017 & + & + \\
\hline Oscillatoria $\mathrm{sp}$ & + & + \\
\hline LPP-group cyanobacterium isolate str. QSSC5cya QSSC5cya & + & + \\
\hline Oscillatoria neglecta str. $M-82$ & + & + \\
\hline Plectonema sp. str. F3 & + & + \\
\hline lichen-dominated Antarctic cryptoendolithic community clone FBP403 & + & + \\
\hline sponge clone TK09 & - & + \\
\hline Synechococcus sp. str. PCC 7502 & - & + \\
\hline Cape Hatteras picoplankton clone OM164 & + & + \\
\hline Skeletonema pseudocostatum str. CSIRO CS-76 & + & + \\
\hline Toolik Lake main station at $3 \mathrm{~m}$ depth clone TLM14 & + & + \\
\hline travertine hot spring clone SM2B11 & + & + \\
\hline Cape Hatteras picoplankton clone OM270 & - & + \\
\hline Emiliania huxleyi str. Plymouth Marine Laborator PML 92 & + & + \\
\hline Cyanidium caldarium str. 14-1-1 & + & + \\
\hline plastid clone ML310M-37 & - & + \\
\hline Euglena tripteris str. $U W O B$ & + & + \\
\hline Lepocinclis fusiformis str. ACOI 1025 & + & + \\
\hline
\end{tabular}




\begin{tabular}{|c|c|c|}
\hline Adiantum pedatum & + & + \\
\hline Calypogeia muelleriana & + & + \\
\hline Mitrastema yamamotoi & + & + \\
\hline Solanum nigrum & + & + \\
\hline Epifagus virginiana -- chloroplast & + & + \\
\hline Pisum sativum -- chloroplast & + & + \\
\hline Cycas revoluta & + & + \\
\hline soil clone PBS-II-1 & + & - \\
\hline bacterioplankton clone ZA3648c & + & + \\
\hline Sargasso Sea & - & + \\
\hline anaerobic benzene-degrading clone Cart-N4 & + & + \\
\hline Solibacter usitatus Ellin6076 & + & + \\
\hline TCE-contaminated site clone FTL227 & + & + \\
\hline uranium mining waste pile clone JG37-AG-39 sp. & + & + \\
\hline Great Artesian Basin clone B27 & + & + \\
\hline Great Artesian Basin clone B11 & + & - \\
\hline DCP-dechlorinating consortium clone SHA-18 & + & + \\
\hline soil clone RB41 & + & + \\
\hline forested wetland clone FW45 & + & + \\
\hline $\begin{array}{l}\text { soil sample uranium mining waste pile near town Johanngeorgenstadt clone } \\
\text { JG36-TzT-77 bacterium }\end{array}$ & + & + \\
\hline soil isolate Ellin337 & + & + \\
\hline forested wetland clone FW47 & + & + \\
\hline PCE-contaminated site clone CLil14 & + & + \\
\hline grassland soil clone DA052 & + & + \\
\hline PCB-polluted soil clone WD228 & + & + \\
\hline soil clone UA2 & + & + \\
\hline Acidobacterium capsulatum & + & + \\
\hline $\begin{array}{l}\text { soil sample uranium mining waste pile near town Johanngeorgenstadt clone } \\
\text { JG36-TzT-31 bacterium }\end{array}$ & + & + \\
\hline acid mine drainage clone TRB82 & + & + \\
\hline PCE-contaminated site clone CLs 73 & + & + \\
\hline PCB-polluted soil clone WD217 & + & + \\
\hline coal effluent wetland clone FW92 & + & + \\
\hline sphagnum peat bog clone $K-5 b 10$ & + & + \\
\hline Spirochaeta sp. str. BHI80-158 & + & + \\
\hline termite gut homogenate clone $R s-B 68 \mathrm{sp}$. & - & + \\
\hline Mono Lake at depth 23 m station 6 July 2000 clone ML623J-23 bacterium & + & - \\
\hline spirochete clone ML320J-13 & + & + \\
\hline Spironema culicis str. BR91 & + & + \\
\hline Treponema sp. str. 7CPL208 & + & + \\
\hline Treponema sp & + & + \\
\hline Treponema sp. str. III:C:BA213 & + & + \\
\hline termite gut clone $N k S 34$ & + & + \\
\hline termite gut homogenate clone Rs-C47 sp. & - & + \\
\hline forested wetland clone RCP1-96 & + & + \\
\hline termite gut clone NkS-Ste2 & - & + \\
\hline termite gut homogenate clone Rs-J42 sp. & - & + \\
\hline termite gut homogenate clone Rs-B69 sp. & + & + \\
\hline
\end{tabular}




\begin{tabular}{|c|c|c|}
\hline termite gut clone NkS5O & + & + \\
\hline Mixotricha paradoxa is flagellate hindgut Mastotermes darwiniensis clone mp3 of & - & + \\
\hline termite gut homogenate clone Rs-D52 sp. & - & + \\
\hline Treponema primitia str. ZAS-1 & + & + \\
\hline Mixotricha paradoxa is flagellate hindgut Mastotermes darwiniensis clone mpl of & - & + \\
\hline termite gut homogenate clone BCf4-14 & + & + \\
\hline termite gut homogenate clone $B C f 8-03$ & + & + \\
\hline termite gut homogenate clone Rs-J58 sp. & + & + \\
\hline termite hindgut clone mpsp2 & + & + \\
\hline termite gut homogenate clone Rs-J64 sp. & + & + \\
\hline termite gut homogenate clone BCf10-21 & - & + \\
\hline termite gut clone NkS39 & + & + \\
\hline termite gut homogenate clone Rs-A43 sp. & - & + \\
\hline termite gut clone $N k S$-Oxy 25 & + & + \\
\hline Spirochaeta sp & + & + \\
\hline Mixotricha paradoxa is flagellate hindgut Mastotermes darwiniensis clone mp4 & + & + \\
\hline termite gut clone $N k S 7$ & - & + \\
\hline TCE-contaminated site clone ccslm 226 & + & - \\
\hline termite gut clone NkS83 & + & + \\
\hline termite gut homogenate clone Rs-D46 sp. & - & + \\
\hline forested wetland clone RCP1-64 & + & + \\
\hline neutral $p H$ mine biofilm clone $44 a-B 1-48$ & - & + \\
\hline Leptospira interrogans serovar Copenhageni str. Fiocruz L1-130 & - & + \\
\hline Rocky Mountain alpine soil clone $W 2 b-8 C$ & + & + \\
\hline Great Artesian Basin clone B35 & + & + \\
\hline Gluconacetobacter europaeus str. ZIM B028 V3 & + & + \\
\hline Acetobacter pomorum str. LTH2458 & + & + \\
\hline deep-sea sediment clone $P_{-} w p 0211$ & - & + \\
\hline diesel-polluted Bohai Gulf isolate str. M-5 M-5 & + & + \\
\hline Thalassospira lucentensis & - & + \\
\hline Scrippsiella trochoidea NEPCC 15 & + & + \\
\hline Roseospira thiosulfatophila AT2115 & + & - \\
\hline rhizosphere clone wr0007 & - & + \\
\hline soil isolate Ellin333 & - & + \\
\hline Dechlorospirillum sp. str. SN1 & + & + \\
\hline sphagnum peat bog clone $K-5 b 5$ & + & + \\
\hline forested wetland clone RCP2-92 & + & + \\
\hline Anabaena circinalis $A W Q C 118 C$ isolate str. UNSW7 & + & + \\
\hline Mammoth cave clone CCU22 & + & + \\
\hline soil near uranium mill tailings clone $\mathrm{KCM}-\mathrm{C}-45$ & + & + \\
\hline Rhodocista pekingensis str. 3-p & + & + \\
\hline uranium mining waste pile near Johanngeorgenstadt soil clone JG37-AG-102 & + & + \\
\hline acid mine drainage clone ASLA5 & + & + \\
\hline Azospirillum species & + & + \\
\hline Great Artesian Basin clone B79 & + & + \\
\hline Azospirillum sp. str. ASP-1 & + & + \\
\hline Rhodocista sp. AR2107 & + & + \\
\hline Pseudovibrio denitrificans str. DN34 & + & + \\
\hline
\end{tabular}




\begin{tabular}{|c|c|c|}
\hline Mammoth cave clone CCM16b & + & + \\
\hline peat soil microcosm clone LO13.3 & - & + \\
\hline heavy metal-contaminated soil clone a13111 & + & + \\
\hline Hyphomicrobium facile str. $\mathrm{H}-526$ & + & + \\
\hline Hyphomicrobium aestuarii str. DSM 1564 & + & + \\
\hline uranium mining waste pile clone JG34-KF-416 & + & + \\
\hline Beijerinckia indica & + & + \\
\hline Azorhizobium caulinodans str. ORS 571 & + & + \\
\hline heavy metal-contaminated soil clone a13115 & + & + \\
\hline Microvirga subterranea str. FaiI4; ATCC BAA-295; DSM 14364 & + & + \\
\hline EBPR sludge lab scale clone HP1B78 & - & + \\
\hline grassland soil clone DA122 & - & + \\
\hline Rhodoplanes sp. str. HA17 & + & - \\
\hline Rhizobiales str. A48 & + & + \\
\hline Thiobacillus sp. str. 104 & + & + \\
\hline Xanthobacter agilis str. SA35 & - & + \\
\hline Blastochloris sulfoviridis str. GN1 & + & + \\
\hline Rhodoplanes elegans str. AS130 & + & + \\
\hline soil isolate Ellin362 & + & + \\
\hline Bosea thiooxidans TJI & + & + \\
\hline Mammoth cave clone CCU18 & + & + \\
\hline Mammoth cave clone CCM24a & + & + \\
\hline denitrifying reactor clone 92 & + & + \\
\hline uranium mining mill tailing clone GR-WP33-3 GR-WP33-3 & - & + \\
\hline heavy metal-contaminated soil clone a13113 & + & + \\
\hline Methylosinus sporium & + & + \\
\hline sludge clone A2O & + & + \\
\hline Methylosinus trichosporium & + & + \\
\hline Methylocella palustris str. $\mathrm{H} 4$ & + & + \\
\hline acidic forest soil clone UP8 & + & + \\
\hline Mammoth cave clone CCM12a & + & - \\
\hline $13 C$ - extracted $13 C$-methanol exposed soil clone UP2 proteobacterium & - & + \\
\hline Methylocella tundrae str. Y1 & + & + \\
\hline uranium mill tailings clone Gitt-KF-194 & + & + \\
\hline soil isolate Ellin340 & - & + \\
\hline Methylobacterium thiocyanatum str. ALL/SCN-P & + & + \\
\hline Methylobacterium fujisawaense & + & + \\
\hline Methylobacterium organophilum str. JCM 2833 & - & + \\
\hline Bosea massiliensis str. 63287 & + & + \\
\hline Oligotropha carboxidovorans str. $\$ 23$ & + & + \\
\hline Afipia clevelandensis & + & + \\
\hline Nitrobacter hamburgensis str. X14 & + & + \\
\hline Nitrobacter sp. str. KB212 & - & + \\
\hline Rhodopseudomonas palustris str. GH & + & + \\
\hline Rhodopseudomonas palustris str. ATCC 17001 & + & + \\
\hline Afipia genosp. 4 str. G3644 & + & + \\
\hline Rhodopseudomonas rhenobacensis str. Klemme Rb & + & + \\
\hline Bradyrhizobium japonicum HAl & + & + \\
\hline
\end{tabular}




\begin{tabular}{|c|c|c|}
\hline Bradyrhizobium japonicum str. USDA 38 & + & + \\
\hline Bradyrhizobium japonicum str. DASA37026 & - & + \\
\hline Bradyrhizobium elkanii str. USDA 76 & + & + \\
\hline heavy metal-contaminated soil clone a13131 & + & + \\
\hline Bradyrhizobium str. YB2 & + & + \\
\hline Afipia genosp. 2 str. G4438 & + & + \\
\hline $\begin{array}{l}\text { ground water deep-well injection disposal site radioactive wastes Tomsk-7 clone } \\
\text { S15A-MN96 proteobacterium }\end{array}$ & + & + \\
\hline Bradyrhizobium sp. str. 2FB3 & + & - \\
\hline Afipia genosp. 10 str. G8996 & + & + \\
\hline Bradyrhizobium elkanii str. SEMIA 6028 & + & + \\
\hline Bradyrhizobium sp. str. KKII4 & + & + \\
\hline Bradyrhizobium japonicum SD5 & + & + \\
\hline Bradyrhizobium japonicum str. IAM 12608 & + & + \\
\hline temperate estuarine mud clone HC65 & + & + \\
\hline Mesorhizobium mediterraneum str. PECA2O & + & + \\
\hline Roseospirillum parvum str. $930 \mathrm{I}$ & + & + \\
\hline hydrocarbon-degrading consortium clone 4-Org2-22 & + & + \\
\hline Phyllobacterium trifolii str. PETPO2 & + & + \\
\hline marine bacterioplankton clone $\mathrm{MB13F01}$ & + & + \\
\hline lake microbial mat isolate str. $R-9219$ & + & + \\
\hline Ahrensia kielensis str. IAM12618 & + & + \\
\hline bacterioplankton clone AEGEAN_108 & + & + \\
\hline Phyllobacterium myrsinacearum HM35 & + & + \\
\hline Aminobacter aminovorans str. DSM7048T & + & + \\
\hline Pseudaminobacter salicylatoxidans str. KTC001 & + & + \\
\hline Waste-gas biofilter clone BIwiil & + & + \\
\hline Ochrobactrum anthropi str. ESCI & + & + \\
\hline Mycoplana dimorpha str. IAM 13154 & + & + \\
\hline soil isolate Ellin332 & + & + \\
\hline Shinella zoogloeoides str. ATCC 19623 & + & + \\
\hline Sinorhizobium fredii str. ATCC35423 & + & + \\
\hline Sinorhizobium meliloti str. 1021 & - & + \\
\hline Ensifer adhaerens str. LMG 20582 & + & + \\
\hline hydrocarbon-degrading consortium clone 4-Org1-36 & + & + \\
\hline Pleomorphomonas oryzae str. $B-32$ & + & + \\
\hline marine isolate JP57 & + & + \\
\hline Rhizobium giardinii str. H152 & + & + \\
\hline India: Himalayas Kaza Spiti Valley Cold Desert isolate str. Kaza-35 Kaza-35 & + & + \\
\hline Rhizobium tropici str. LMG 9517 & + & + \\
\hline Rhizobium mongolense str. USDA 1832 & + & + \\
\hline Rhizobium gallicum str. FL27 & + & + \\
\hline sludge clone H6 & + & + \\
\hline Rhizobium etli str. USDA 2667 ATCC 14483 SEMIA 043 & + & + \\
\hline Rhizobium leguminosarum bv. viciae str. USDA 2508 & + & + \\
\hline termite gut homogenate clone $R s-D 84$ proteobacterium & + & + \\
\hline uranium mining waste pile clone JG34-KF-245 proteobacterium & + & + \\
\hline termite gut homogenate clone Rs-B50 proteobacterium & + & + \\
\hline PCE-contaminated site clone CLi8 & + & + \\
\hline
\end{tabular}




\begin{tabular}{|c|c|c|}
\hline Mammoth cave clone CCM21a & + & + \\
\hline Agrobacterium tumefaciens TG14 & + & + \\
\hline Rhizobium sp. str. SH19312 & + & + \\
\hline Agrobacterium tumefaciens str. C58 Cereon & + & + \\
\hline Agrobacterium tumefaciens $C 4$ & + & + \\
\hline Rhizobium huautlense str. SO2 () & + & + \\
\hline Bartonella schoenbuchensis str. RI & + & + \\
\hline $\begin{array}{l}\text { Mariana trough hydrothermal vent water } 0.2 \text { micro- } m \text { filterable fraction clone } \\
M T-N B 25\end{array}$ & + & + \\
\hline aortic heart valve patient with endocarditis clone v9 & + & + \\
\hline Bartonella quintana str. Toulouse & + & + \\
\hline Bartonella henselae str. Houston-1 & + & + \\
\hline Caulobacter sp. str. FWC38 & + & + \\
\hline Brevundimonas sp. str. MCS17 & + & - \\
\hline Brevundimonas intermedia str. MBIC2712 ATCC15262 & + & + \\
\hline Brevundimonas vesicularis str. IAM $12105 T$ & + & + \\
\hline Brevundimonas diminuta str. DSM 1635 & + & + \\
\hline Brevundimonas diminuta str. IAM $12691 T$ & + & + \\
\hline Brevundimonas bacteroides str. CB7 & + & + \\
\hline Brevundimonas subvibrioides str. CB81 & + & + \\
\hline Brevundimonas sp. str. FWC4O & + & + \\
\hline marine clone Arctic96A-1 & + & + \\
\hline Roseobacter clone NAC11-3 & + & + \\
\hline Sulfitobacter sp. PIC-72 & + & + \\
\hline Arctic sea ice ARK10013 & + & + \\
\hline Loktanella vestfoldensis str. LMG 22003 & + & + \\
\hline Antarctic seawater isolate str. $R 7706$ & + & + \\
\hline Roseobacter sp. str. KT0202a & + & + \\
\hline Scrippsiella trochoidea NEPCC 15 & + & + \\
\hline Sulfitobacter sp. BIO-11 & + & + \\
\hline Prionitis lanceolata gall symbiont & + & + \\
\hline Roseobacter sp. str. KT0917 & + & - \\
\hline Arctic sea ice ARK10226 & + & + \\
\hline Roseobacter sp. str. ANT9274 & + & + \\
\hline coastal sediment clone & + & - \\
\hline Arctic sea ice ARK10055 & + & + \\
\hline Leisingera methylohalidivorans str. MB2 & + & + \\
\hline Rhodobacter group clone LA1-B32N & - & + \\
\hline Ruegeria atlantica str. WNA2 & + & - \\
\hline Mono Lake at depth 35 m station 6 July 2000 clone ML635J-2 proteobacterium & + & + \\
\hline Roseobacter sp. str. ARK9990 & + & - \\
\hline Methylarcula sp. BIO-24 & + & + \\
\hline unialgal raphidophyte Chattonella marina isolate str. Fl90-32 bacterium & + & + \\
\hline Roseobacter sp. $4318-8 / 1$ & + & + \\
\hline Ruegeria atlantica str. IAM14464 & + & - \\
\hline Loktanella salsilacus str. LMG 22000 & + & - \\
\hline Paracoccus pantotrophus str. TUT1022 & + & + \\
\hline Paracoccus yeei str. G6446 & + & - \\
\hline Paracoccus alcaliphilus str. JCM 7364 & + & + \\
\hline
\end{tabular}




\begin{tabular}{|c|c|c|}
\hline Paracoccus carotinifaciens str. E-396 & + & + \\
\hline Paracoccus solventivorans str. ATCC 700252 & + & - \\
\hline Rhodobacter sp. AP-10 & + & + \\
\hline Gram-negative MM 1 & + & + \\
\hline Pseudorhodobacter ferrugineus str. IAM12616 & + & + \\
\hline Colored moderately thermophilic paper-machine biofilms paper machine biofilm & + & + \\
\hline deep sea sediment clone $N K B 7$ & + & + \\
\hline non-EBPR sludge clone SBRT155 & + & + \\
\hline $\begin{array}{l}\text { lichen-dominated Antarctic cryptoendolithic community clone FBP492 } \\
\text { proteobacterium }\end{array}$ & + & - \\
\hline sludge clone A6 & + & - \\
\hline Rhodobacter sphaeroides str. 2.4 .1 & + & + \\
\hline Rhodobacter massiliensis str. Framboise & + & - \\
\hline Rhodobacter capsulatus str. B10 & + & - \\
\hline Jannaschia sp. DFL-38 & + & - \\
\hline bacterioplankton clone ZA2526c & - & + \\
\hline Rhodovulum sp. CP-10 & + & - \\
\hline sponge clone TK03 & + & + \\
\hline Rhodovulum strictum str. MB-G2 & + & - \\
\hline Maricaulis maris str. ATCC 15269 & + & + \\
\hline Maricaulis indicus str. MCS26 & + & + \\
\hline travertine hot spring clone SM2C07 & + & + \\
\hline Scrippsiella trochoidea NEPCC 15 & + & + \\
\hline Hyphomonas johnsonii str. MHS-2 & + & - \\
\hline Candidatus Pelagibacter ubique str. HTCC1002 & + & + \\
\hline marine clone Arctic $95 D-8$ & + & - \\
\hline bacterioplankton clone AEGEAN_233 & - & + \\
\hline marine clone Arctic $96 B-6$ & + & + \\
\hline marine bacterioplankton clone MB12A07 & + & - \\
\hline ferromanganous micronodule clone MND8 & + & + \\
\hline periodontal pocket clone $10 B 6$ & + & + \\
\hline Rickettsia rickettsii str. Sawtooth & + & + \\
\hline termite gut homogenate clone $R s$-B60 proteobacterium & + & + \\
\hline termite gut homogenate clone Rs-M62 proteobacterium & + & + \\
\hline Rickettsia bellii str. strains $369-C$ and G2D42 & + & + \\
\hline Anaplasma bovis & - & + \\
\hline Wolbachia pipientis & + & + \\
\hline Wolbachia sp & + & + \\
\hline Wolbachia sp. Dlem16SWol & + & + \\
\hline coal effluent wetland clone RCP124 & + & + \\
\hline Rhinocyllus conicus endosymbiont & + & - \\
\hline Wolbachia pipientis & + & + \\
\hline Sphingobium chungbukense str. DJ77 & + & + \\
\hline Sphingobium yanoikuyae str. GIFU9882 & + & + \\
\hline Afipia genosp. 13 str. G8991 & + & + \\
\hline Sphingomonas sp. str. SAFR-010 & + & + \\
\hline isolate str. '\#33 orange' & + & + \\
\hline Sphingomonas echinoides & - & + \\
\hline Sphingomonas sp. str. SAFR-027 & + & + \\
\hline
\end{tabular}




\begin{tabular}{|c|c|c|}
\hline Sphingomonas sp. V1 str. V21 & + & + \\
\hline Sphingomonas paucimobilis str. GIFU2395 & + & + \\
\hline Kaistobacter koreensis str. PB229 & - & + \\
\hline heavy metal-contaminated soil clone a13102 & - & + \\
\hline Sphingomonas asaccharolytica str. IFO 10564-T & + & + \\
\hline pea aphid symbiont clone APe4_19 & + & + \\
\hline travertine hot spring clone SM2B06 & + & + \\
\hline soil clone $768-2$ & - & + \\
\hline marine clone Arctic95C-5 & + & + \\
\hline Sphingomonas sp. str. B9 & + & + \\
\hline Sphingopyxis flavimaris str. SW-151 & + & + \\
\hline $\begin{array}{l}\text { lichen-dominated Antarctic cryptoendolithic community clone FBP255 } \\
\text { proteobacterium }\end{array}$ & + & + \\
\hline activated sludge clone 1958 & - & + \\
\hline Novosphingobium sp. str. K16 & + & + \\
\hline Novosphingobium subarcticum LH128 & + & + \\
\hline Novosphingobium tardaugens str. ARI-1 & - & + \\
\hline Sphingomonas sp. str. IW3 & - & + \\
\hline Novosphingobium subterraneum str. IFO 16086 & - & + \\
\hline Novosphingobium sp. str. J30 & - & + \\
\hline Novosphingobium stygium str. IFO 16085 & + & + \\
\hline Japan:NaganoLake Suwa isolate str. $7 C Y$ & + & + \\
\hline Sphingopyxis chilensis str. S37 & - & + \\
\hline Sphingopyxis witflariensis str. W-50 & + & + \\
\hline Porphyrobacter tepidarius str. OK5APO & + & + \\
\hline Porphyrobacter tepidarius str. DSM 10594 & + & + \\
\hline Erythrobacter sp. str. AS-45 & - & + \\
\hline str. MBIC3035 PC4 & + & + \\
\hline Aquaspirillum serpens str. IAM 13944 & + & + \\
\hline Aquaspirillum putridiconchylium str. IAM 14964 & + & + \\
\hline Neisseria sp. str. CCUG 46910 & + & + \\
\hline Nitrosovibrio sp. str. RY6A & - & + \\
\hline Nitrosospira sp. str. TYM9 & + & + \\
\hline sample taken upstream landfill clone BVC77 landfill & + & - \\
\hline Nitrosospira briensis str. Nsp10 & + & + \\
\hline Nitrosospira multiformis & + & + \\
\hline Nitrosomonas sp. str. Nm86 & + & + \\
\hline Nitrosomonas sp. str. Nm59 & + & + \\
\hline freshwater clone PRD01a011B & + & + \\
\hline Nitrosomonas europaea str. ATCC 19718 & + & + \\
\hline Nitrosomonas eutropha str. Nm57 & + & + \\
\hline travertine hot spring clone SM1E12 & + & - \\
\hline $\begin{array}{l}\text { silica sinter depositing geothermal power station discharge drain clone ST01- } \\
\text { SN1D proteobacterium }\end{array}$ & - & + \\
\hline EBPR sludge clone SA34 & + & - \\
\hline agricultural soil clone SC-I-71 & + & + \\
\hline iron-oxidizing acidophile isolate $m-1$ & + & - \\
\hline Uranium mill tailings soil sample clone Sh765B-TzT-132 proteobacterium & + & + \\
\hline Zoogloea ramigera str. ATCC $19544(T)$ & + & + \\
\hline
\end{tabular}




\begin{tabular}{|c|c|c|}
\hline sludge clone $\mathrm{H} 13$ & + & + \\
\hline EBPR sludge lab scale clone HPIA03 & + & + \\
\hline Thauera aromatica str. LG356 & + & + \\
\hline uranium mining mill tailing clone $G R-W P 33-36 G R-W P 33-36$ & + & + \\
\hline uranium mining waste pile near Johanngeorgenstadt soil clone JG37-AG-35 & + & + \\
\hline termite gut homogenate clone $R s-B 77$ proteobacterium & + & + \\
\hline Azoarcus tolulyticus str. $2 F B 6$ & + & - \\
\hline$P+$ sludge clone $G C 24$ & + & + \\
\hline Thiobacillus aquaesulis & + & + \\
\hline penguin droppings sediments clone KD1-79 & + & + \\
\hline swine intestine clone p-861-a5 & + & + \\
\hline Alcaligenes defragrans str. PD-19 & + & + \\
\hline Alcaligenes faecalis str. M3A & + & + \\
\hline Achromobacter subsp. denitrificans str. DSM $30026(T)$ & + & + \\
\hline Waste-gas biofilter clone BIfciii38 & + & - \\
\hline Alcaligenes sp. str. VKM B-2263 dcm6 & + & + \\
\hline Waste-gas biofilter clone BIfdi44 & + & + \\
\hline Comamonas terrigena str. IAM $12052 T$ & + & - \\
\hline EBPR sludge lab scale clone HP1B33 & + & + \\
\hline Comamonas testosteroni & - & + \\
\hline Comamonas testosteroni str. SMCC B329 & + & + \\
\hline Guaymas Basin hydrothermal sediment clone a2b013 & + & + \\
\hline oral periodontitis clone EW086 & + & + \\
\hline Comamonas sp. str. PJ712 & + & + \\
\hline Hydrogenophaga sp. str. ATCC BAA-306 YEDI-18 ATCC & + & + \\
\hline travertine hot spring clone SMIEOI & + & + \\
\hline Hydrogenophaga taeniospiralis str. ATCC 49743 & + & + \\
\hline Mars Odyssey Orbiter and encapsulation facility clone T5-1 sp. & + & + \\
\hline freshwater clone PRD01b009B & + & + \\
\hline Toolik Lake main station at $3 \mathrm{~m}$ depth clone TLM04/TLMdgge03 proteobacterium & - & + \\
\hline Polaromonas vacuolata str. 34-P & + & + \\
\hline Toolik Lake main station at $3 \mathrm{~m}$ depth clone TLM05/TLMdgge 10 proteobacterium & + & + \\
\hline Polaromonas naphthalenivorans str. CJ2 & - & + \\
\hline Xylophilus ampelinus str. ATCC 33914 & + & + \\
\hline penguin droppings sediments clone KD2-104 & - & + \\
\hline penguin droppings sediments clone KD5-43 & + & + \\
\hline$M C B$-contaminated groundwater-treating reactor clone $R B 9 C 10$ & + & + \\
\hline Arctic sea ice ARK10281 & + & + \\
\hline penguin droppings sediments clone KD3-141 & - & + \\
\hline Pseudomonas lanceolata str. ATCC $14669 T$ & + & + \\
\hline Delftia tsuruhatensis str. AD9 & + & + \\
\hline Anabaena circinalis AWQC118C isolate str. UNSW5 & - & + \\
\hline Variovorax paradoxus & + & + \\
\hline napthalene-contaminated sediment clone 76 & + & + \\
\hline Variovorax paradoxus str. IAM 12373 & + & + \\
\hline penguin droppings sediments clone KD2-46 & - & + \\
\hline PCB-polluted soil clone WD291 & + & + \\
\hline soil clone & - & + \\
\hline
\end{tabular}




\begin{tabular}{|c|c|c|}
\hline Hydrogenophaga flava str. DSM 619T & + & + \\
\hline uranium mill tailings clone Gitt-KF-21 & - & + \\
\hline strain isolate str. $r M 4$ & + & + \\
\hline Variovorax paradoxus TG27 & + & + \\
\hline marine? clone KD1-99 & + & + \\
\hline Acidovorax sp. str. OS-6 & + & + \\
\hline Ottowia thiooxydans str. K11 & + & + \\
\hline hydrocarbon-degrading consortium clone AF1-8 & + & + \\
\hline denitrifying reactor clone 81 & + & + \\
\hline Acidovorax konjaci str. DSM 7481 & + & + \\
\hline Acidovorax delafieldii str. ATCC 17505 & + & + \\
\hline Acidovorax facilis str. CCUG 2113 & + & + \\
\hline Acidovorax avenae subsp. cattleyae str. NCPPB 961 subsp. & + & + \\
\hline strain isolate str. $r J 10$ & + & + \\
\hline Acidovorax defluvii str. BSB411 & + & + \\
\hline Aquaspirillum metamorphum str. DSM 1837 & + & + \\
\hline isolate str. A0640 & + & + \\
\hline Rubrivivax gelatinosus str. A3 & + & + \\
\hline Schlegelella sp. str. KBla & - & + \\
\hline Limnobacter thiooxidans str. CS-K2 & + & + \\
\hline Leptothrix discophora str. SS-1 & + & - \\
\hline Leptothrix cholodnii str. CCM 1827 & + & + \\
\hline isolate str. A1004 & + & - \\
\hline hydrothermal vent clone VC2.1 Bac29 & - & + \\
\hline Aquabacterium parvum str. B6 & + & + \\
\hline Anoxobacterium dechloraticum & + & + \\
\hline uranium mill tailings soil sample clone $G u B H 2-A D-29$ proteobacterium & + & + \\
\hline Burkholderia glathei str. ATCC $29195 T$ & + & + \\
\hline $\begin{array}{l}\text { soil sample uranium mining waste pile near town Johanngeorgenstadt clone } \\
\text { JG36-TzT-215 proteobacterium }\end{array}$ & + & + \\
\hline Burkholderia sp. & + & + \\
\hline Burkholderia graminis str. AUS35 & + & + \\
\hline Burkholderia caryophylli str. ATCC 25418 & + & + \\
\hline forested wetland clone FW145 & + & + \\
\hline Elbe River snow isolate Iso18 Iso18_1411 & + & + \\
\hline Burkholderia cepacia LS2.4 & + & + \\
\hline Chitinimonas taiwanensis str. $c f$ & + & + \\
\hline Burkholderia cepacia & + & + \\
\hline Herbaspirillum sp. str. NAH4 & + & + \\
\hline uranium mining waste pile clone JG37-AG-125 proteobacterium & + & + \\
\hline Massilia timonae timone & + & + \\
\hline Diaphorina citri symbiont & + & + \\
\hline Paucimonas lemoignei str. ATCC $17989 T$ & + & + \\
\hline napthalene-contaminated sediment clone 29 & - & + \\
\hline Collimonas fungivorans str. Ter331 & + & + \\
\hline Oxalobacter formigenes str. OXB ovinen rumen & + & + \\
\hline isolate str. A1020 & + & + \\
\hline Aquaspirillum arcticum str. IAM 14963 & + & + \\
\hline Janthinobacterium agaricidamnosum str. W1r3T & + & + \\
\hline
\end{tabular}




\begin{tabular}{|c|c|c|}
\hline Herbaspirillum seropedicae str. DSM 6445 ATCC 35892 & + & + \\
\hline 2-HNA producing isolate MC13289 & - & + \\
\hline Wautersia basilensis str. DSM 11853 & + & + \\
\hline Wautersia paucula str. LMG 3413 & + & + \\
\hline Cupriavidus necator & + & + \\
\hline Ralstonia detusculanense str. APF11 & + & + \\
\hline Halorhodospira neutrophila str. SG 3304 & + & + \\
\hline Ectothiorhodospiraceae clone LA7-B9 & + & + \\
\hline hypersaline Mono Lake clone ML110J-5 & + & + \\
\hline Alkalispirillum mobile & + & + \\
\hline Mono Lake at depth $2 \mathrm{~m}$ station $6 \mathrm{July} 2000$ clone ML602J-47 proteobacterium & - & + \\
\hline uranium waste soil clone JG30-KF-CM35 & + & + \\
\hline activated sludge clone SBRH1O & + & + \\
\hline Mammoth Cave sediment clone CCD24 & + & + \\
\hline acid mine drainage clone BA11 & + & + \\
\hline Acidithiobacillus ferrooxidans str. D2 & + & + \\
\hline Acidithiobacillus albertensis str. DSM 14366 & + & + \\
\hline Nitrosococcus halophilus & + & - \\
\hline forested wetland clone RCP2-96 & + & + \\
\hline Nitrosococcus oceanus & + & + \\
\hline marine sediment clone Limfjorden L8 & + & + \\
\hline Thioploca ingrica & + & - \\
\hline marine sediment clone Limfjorden L10 & + & + \\
\hline Beggiatoa sp. str. MS-81-1c & + & + \\
\hline Beggiatoa alba str. B18LD; ATCC 33555 & + & + \\
\hline marine sediment clone Tokyo Bay $D$ & + & - \\
\hline Allochromatium sp. AT2202 & - & + \\
\hline Thiocapsa litoralis & + & + \\
\hline deep-sea sediment clone BDI-1 & - & + \\
\hline Chromatiaceae clone LA4-B63N & + & + \\
\hline Thiorhodovibrio winogradskyi & + & + \\
\hline Thiococcus sp. AT2204 & + & + \\
\hline Thiorhodovibrio sibirica & + & + \\
\hline uranium mining waste pile clone JG37-AG-14 proteobacterium & + & + \\
\hline forested wetland clone $R C P 2-54$ & + & + \\
\hline isolate str. IR & + & + \\
\hline Acidithiobacillus ferrooxidans str. DSM 2392 & + & + \\
\hline Solemya reidi symbiont 2 & + & + \\
\hline deepest cold-seep area Japan Trench clone JTB35 proteobacterium & + & + \\
\hline Norway:(Svalbard)Hornsund clone Sva0864 & + & + \\
\hline Selenate-reducing isolate str. $\mathrm{KE} 4 \mathrm{OHI}$ & + & + \\
\hline marine sediment clone B2M54 & + & + \\
\hline f cytometric sorted marine sample subpopulation 3 clone ZD0408 bacterium & + & + \\
\hline hydrothermal sediment clone AF420367 & + & + \\
\hline inactive deep-sea hydrothermal vent chimneys clone IheB2-13 & + & + \\
\hline marine clone Arctic97C-5 & + & + \\
\hline Lucina nassula gill symbiont & + & + \\
\hline Codakia orbicularis gill symbiont & - & + \\
\hline
\end{tabular}




\begin{tabular}{|c|c|c|}
\hline unclassified Lamellibrachia sp. 1 symbiont Lamellibrachia & + & + \\
\hline Mammoth cave clone CCM19a & + & + \\
\hline Seepiophila jonesi symbiont & + & + \\
\hline microbial mat cave sulfidic spring clone LKC3_19.29 & + & - \\
\hline bacterioplankton clone ZA2525c & + & + \\
\hline inactive deep-sea hydrothermal vent chimneys clone IheB2-31 & + & + \\
\hline Bathymodiolus thermophilus gill symbiont & + & + \\
\hline sea water isolate str. DBF-MAK & + & + \\
\hline Cycloclasticus spirillensus str. M4-6 & + & - \\
\hline Methylophaga alcalica str. M39 & + & + \\
\hline Methylophaga sp. str. V4.ME.29=MM_2343 & + & + \\
\hline Tilapia parasite TPT-541 & + & + \\
\hline uranium waste soil clone JG30a-KF-21 & + & + \\
\hline Halothiobacillus sp. & + & + \\
\hline Halothiobacillus sp. str. RA13 & - & + \\
\hline Halothiobacillus neapolitanus str. DSM 581 & - & + \\
\hline Halothiobacillus hydrothermalis str. $r 3$ & + & + \\
\hline Halothiobacillus halophilus & - & + \\
\hline Halothiobacillus sp. str. WJ18 & - & + \\
\hline water 5 m downstream manure clone $35 d s 5$ & + & + \\
\hline hexane degrading biofilter isolate MN 154.3 & + & - \\
\hline Germany:Schlema/Alberoda clone GR-296.I.104 proteobacterium & - & + \\
\hline Nevskia ramosa & - & + \\
\hline pea aphid symbiont clone APe4_38 & + & + \\
\hline uranium mining waste pile clone JG37-AG-94 proteobacterium & + & + \\
\hline Dyemonas todaii str. XD10 & + & + \\
\hline acid mine drainage clone TRA5-3 & + & - \\
\hline Iron oxidising strain $E S-1$ & + & + \\
\hline Thermomonas fusca str. LMG 21738 & + & - \\
\hline Waste-gas biofilter clone BIyi3 & + & + \\
\hline $\begin{array}{l}\text { lodgepole pine rhizosphere soil British Columbia Ministry Forests Long-Term } \\
\text { Soil Productivity }\end{array}$ & + & + \\
\hline travertine hot spring clone SMIE05 & + & + \\
\hline Xanthomonas axonopodis pv. citri str. $M A$ & + & + \\
\hline Stenotrophomonas rhizophila str. e-p10 & + & + \\
\hline Stenotrophomonas maltophilia str. LMG 11104 & + & + \\
\hline Legionella steigerwaltii str. ATCC 35302 & + & + \\
\hline Legionella parisiensis & + & - \\
\hline bacterioplankton clone AEGEAN_234 & + & + \\
\hline Legionella pneumophila str. Paris & + & + \\
\hline 5' clone $C H A B-X I-27$ & + & + \\
\hline uranium mining waste pile clone KF-JG30-B15 KF-JG30-B15 & + & + \\
\hline Legionella rubrilucens str. ATCC 35304 & + & + \\
\hline North Sea clone KTc0924 & + & + \\
\hline \multirow[t]{2}{*}{ uranium mining waste pile soil sample clone JG30-KF-C15 proteobacterium } & + & + \\
\hline & + & + \\
\hline Mars Odyssey Orbiter and encapsulation facility clone T5-3 & + & + \\
\hline Methylococcus capsulatus Bath str. ACM 3302 ATCC 33009 NCIBM 1113 & + & + \\
\hline activated sludge clone SBRL2_19 & + & + \\
\hline
\end{tabular}




\begin{tabular}{|c|c|c|}
\hline activated sludge clone SBRQ157 & + & + \\
\hline activated sludge clone SBRL2_40 & + & + \\
\hline coal tar-contaminated groundwater clone 4-25 & + & + \\
\hline Methylobacter whittenburyi str. 3310 NCIMB 11128 ACM 3306 & - & + \\
\hline Methylobacter psychrophilus str. Z-0021 & + & + \\
\hline $\begin{array}{l}\text { extracted chamber connected to Ocean Drilling Program site } 892 b \text { clone 1-27 } \\
\text { proteobacterium }\end{array}$ & + & - \\
\hline Methylobacter marinus str. A45 & + & + \\
\hline marine sediment above hydrate ridge clone Hyd24-01 proteobacterium & + & + \\
\hline Chromohalobacter israelensis str. ATCC 43985 T & + & + \\
\hline Halomonas desiderata str. FB2 & + & + \\
\hline Boston Harbor surface water isolate str. UMB18C UMB18C & - & + \\
\hline Halomonas sp. SK1 & + & + \\
\hline marine isolate NOR5 & + & - \\
\hline Marinomonas protea & - & + \\
\hline forested wetland clone FW23 & + & + \\
\hline Alcanivorax sp. str. K3-3 (MBIC 4323) & + & + \\
\hline North Sea; NOR3 isolate str. KT0221 & - & + \\
\hline Alcanivorax borkumensis str. LE4 & - & + \\
\hline Alcanivorax sp. str. Hawl & - & + \\
\hline Psychrobacter frigidicola str. DSM 12411 & + & + \\
\hline Moraxella oblonga str. IAM 14971 & + & + \\
\hline Psychrobacter psychrophilus CMS 28 & + & + \\
\hline Alkanindiges hongkongensis str. HKU9 & + & + \\
\hline Acinetobacter junii str. S33 & + & + \\
\hline hydrocarbon-degrading consortium clone AF2-1D & + & + \\
\hline Acinetobacter tandoii str. $4 N 13$ & + & + \\
\hline Acinetobacter haemolyticus & + & + \\
\hline Lyrodus pedicellatus symbiont & + & + \\
\hline Lyrodus pedicellatus symbiont & + & + \\
\hline Pseudomonas aeruginosa str. \#47 & + & + \\
\hline Pseudomonas stutzeri HY-105 & + & + \\
\hline Pseudomonas mendocina str. KR & + & - \\
\hline Pseudomonas fulva str. IAM 1587 & + & + \\
\hline Pseudomonas sp. str. $2 \mathrm{N1-1}$ & + & + \\
\hline $\begin{array}{l}\text { ground water deep-well injection disposal site radioactive wastes Tomsk-7 clone } \\
\text { S15A-MN7 proteobacterium }\end{array}$ & + & + \\
\hline Pseudomonas monteilii str. CIP 104883 & + & + \\
\hline Pseudomonas cf. monteilii 9 & + & + \\
\hline cf. Pseudomonas sp. clone Llangefni 52 & + & + \\
\hline Pseudomonas sp. str. dcm7B & + & + \\
\hline Pseudomonas syringae pv. broussonetiae str. KOZ 8101 pv. & + & + \\
\hline bacterioplankton clone ZA3412c & - & + \\
\hline Beggiatoa sp. str. AA5A & + & + \\
\hline Pseudomonas koreensis str. Ps 9-14 & + & + \\
\hline hydrothermal sediment clone AF420370 & + & + \\
\hline Pseudomonas fluorescens str. CHAO & + & + \\
\hline Pseudomonas syringae pv. theae str. PT1 & + & + \\
\hline Pseudomonas sp. str. AC-167 & + & + \\
\hline
\end{tabular}




\begin{tabular}{|c|c|c|}
\hline Pseudomonas synxantha str. DSM $13080 \mathrm{G}$ & + & + \\
\hline Pseudomonas sp. B65 & + & + \\
\hline Pseudomonas marginalis str. ATCC $10844 T$ & + & + \\
\hline Pseudomonas sp. str. NMX & + & - \\
\hline Pseudomonas putida str. ATCC 17472 & + & + \\
\hline uranium mining mill tailing clone GR-296.II.89 GR-296.II.89 & + & + \\
\hline Pseudomonas extremorientalis str. KMM3447 & + & + \\
\hline Pseudomonas fulgida str. DSM $14938=$ LMG 2146 P 515/12 & + & + \\
\hline Pseudomonas tolaasii str. LMG 2342T() & + & + \\
\hline Pseudomonas sp. SK-1-3-1 & + & + \\
\hline Pseudomonas psychrophila str. E-3 & + & + \\
\hline $\begin{array}{l}\text { silica sinter depositing geothermal power station discharge drain clone ST01- } \\
\text { SN4A proteobacterium }\end{array}$ & - & + \\
\hline Arctic sea ice ARK10148 & + & + \\
\hline Alteromonadaceae isolate str. LA50 & - & + \\
\hline Marinobacter aquaeolei str. KT02ds19 & + & + \\
\hline Arctic sea ice ARK10244 & - & + \\
\hline Alteromonadaceae isolate str. LA13 & + & + \\
\hline Marinobacter lipolyticus str. SM-19 & - & + \\
\hline Marinobacter sp. str. SBS & + & + \\
\hline Marinobacter hydrocarbonoclasticus str. ATCC $27132 T$ & + & + \\
\hline bacterioplankton clone AEGEAN_133 & + & + \\
\hline Arctic sea ice ARK10228 & - & + \\
\hline $\begin{array}{l}\text { Arctic deep sea Isolation common chemoorganotrophic oxygen-respiring polar } \\
\text { current d } 1210\end{array}$ & + & + \\
\hline Marinobacter excellens str. KMM 3809 & + & - \\
\hline Rheinheimera baltica str. OS140 Baltic \# 166 & + & - \\
\hline Alishewanella fetalis str. CCUG 30811 & + & - \\
\hline Colwellia maris str. ABE-1 & + & + \\
\hline Colwellia piezophila str. $Y 223 G$ & + & - \\
\hline Thalassomonas ganghwensis str. JC2041 & + & + \\
\hline Marine isolate str. GK-2001 & + & + \\
\hline Boston Harbor surface water isolate str. UMB6D UMB6D & + & - \\
\hline attached marine recovered surface clone 17 proteobacterium & + & + \\
\hline $\begin{array}{l}\text { Arctic pack ice; northern Fram Strait; } 8031.1 \text { N; } 01 \text { deg } 59.7 \text { min E clone } \\
\text { ARKIA-34 }\end{array}$ & - & + \\
\hline Alteromonas marina str. $S W-47$ & - & + \\
\hline Arctic seawater isolate str. $R 9879$ & + & + \\
\hline Arctic sea ice ARK10108 & + & + \\
\hline Antarctic pack ice Lasarev Sea Southern Ocean clone ANTXI/4_14-62 sea & - & + \\
\hline attached marine recovered surface clone 18 proteobacterium & - & + \\
\hline Alteromonas stellipolaris str. LMG 21861 & + & + \\
\hline sea water isolate str. $B P-P H$ & + & + \\
\hline Alteromonadaceae clone $\mathrm{PH}-\mathrm{B} 55 \mathrm{~N}$ & + & + \\
\hline Pseudoalteromonas sp. str. Bdeep-1 & + & + \\
\hline Alteromonas sp. str. NIBH PIM3 & + & + \\
\hline Pseudoalteromonas sp. str. E36 & + & + \\
\hline marine clone Arctic96B-17 & + & + \\
\hline Pseudoalteromonas $s p$ & + & + \\
\hline
\end{tabular}




\begin{tabular}{|c|c|c|}
\hline Pseudoalteromonas porphyrae str. $\$ 2-65$ & + & + \\
\hline Pseudoalteromonas sp. str. 05 & + & + \\
\hline Shewanella surugensis str. c959 & + & + \\
\hline Photobacterium leiognathi str. LN101 & - & + \\
\hline $\begin{array}{l}\text { Arctic pack ice; northern Fram Strait; } 8031.1 \text { N; } 01 \text { deg } 59.7 \text { min E clone } \\
\text { ARKDMS-58 }\end{array}$ & + & + \\
\hline Vibrio aestuarianus str. KT0901 & - & + \\
\hline Vibrio aestuarianus str. 01/151 & - & + \\
\hline Anaerobiospirillum sp. str. $3 \mathrm{~J} 102$ & + & - \\
\hline Aeromonas sp. PAR2A & + & + \\
\hline Histophilus somni str. CCUG 12839 & + & + \\
\hline Buchnera sp & - & + \\
\hline USA:New York isolate str. KN4 & - & + \\
\hline Alterococcus agarolyticus str. ADT3; CCRC17102 & - & + \\
\hline intestine Zophobas mori clone & + & + \\
\hline Salmonella subsp. enterica serovar Waycross str. Swyl subsp. & - & + \\
\hline Salmonella typhimurium LT2 str. SGSC1412 & - & + \\
\hline Erwinia chrysanthemi str. 571 & - & + \\
\hline Erwinia chrysanthemi str. ATCC 11663 & - & + \\
\hline Erwinia amylovora str. DSM 30165 & - & + \\
\hline Erwinia amylovora str. BC199(=Ea528) & - & + \\
\hline Morganella morganii str. AP28 & - & + \\
\hline Morganella morganii str. ATCC35200 & + & + \\
\hline Pectobacterium cypripedii str. ATCC 29267 & - & + \\
\hline Salmonella bongori str. JEO 4162 & - & + \\
\hline Pantoea agglomerans str. $A 40$ & - & + \\
\hline Baumannia cicadellinicola & + & - \\
\hline Pantoea subsp. stewartii str. GSPB 2626 & - & + \\
\hline Vryburgia amaryllidis symbiont & + & + \\
\hline Dysmicoccus neobrevipes symbiont & + & + \\
\hline Amonostherium lichtensioides symbiont & + & + \\
\hline Baumannia cicadellinicola & + & - \\
\hline Serratia marcescens subsp. sakuensis str. KRED subsp. & - & + \\
\hline Buttiauxella warmboldiae str. DSM 9404 & - & + \\
\hline Enterobacter cloacae Nr. 3 & - & + \\
\hline Enterobacteriaceae CF01Ent-1 & - & + \\
\hline Klebsiella oxytoca str. ChDC OS31 & - & + \\
\hline Enterobacter ludwigii str. EN-119 = DSMZ 16688 & - & + \\
\hline Enterobacter intermedius str. JCM1238 & - & + \\
\hline Raoultella planticola 7 & - & + \\
\hline Raoultella planticola str. DR3 & - & + \\
\hline Klebsiella pneumoniae str. ASRI & - & + \\
\hline Cyphonococcus alpinus symbiont & + & + \\
\hline Serratia proteamaculans str. DSM 4543 & - & + \\
\hline Serratia entomophila str. DSM 12358 & - & + \\
\hline Aranicola proteolyticus & + & + \\
\hline Serratia fonticola str. DSM 4576 & + & + \\
\hline Heteropsylla texana symbiont & + & + \\
\hline Morganella morganii & + & - \\
\hline
\end{tabular}




\begin{tabular}{|c|c|c|}
\hline Morganella morganii str. JU27 & + & - \\
\hline Photorhabdus asymbiotica str. ATCC 43949 & + & - \\
\hline Hafnia alvei & - & + \\
\hline Rahnella aquatilis $k 8$ & - & + \\
\hline Rahnella genosp. 3 str. DSM 30078 & + & + \\
\hline Secondary symbiont type-U Acyrthosiphon pisum (rrs) clone $5 B$ type- $U$ & - & + \\
\hline Yersinia aldovae str. A125 & - & + \\
\hline Desulfonauticus submarinus str. $6 \mathrm{~N}$ & + & + \\
\hline Desulfomicrobium baculatum str. DSM 1742 & + & + \\
\hline Desulfomicrobium baculatum str. X; VKM B-1378; DSM 4 & + & + \\
\hline Desulfovibrio sp. str. Ac5.2 & + & + \\
\hline Desulfovibrio hydrothermalis str. AM13 & - & + \\
\hline granular sludge clone $R 2 b 32$ & - & + \\
\hline Desulfovibrio giganteus str. DSM 4370 & + & + \\
\hline termite gut homogenate clone $R s$-N35 proteobacterium & + & + \\
\hline termite gut homogenate clone $R s-M 72$ proteobacterium & + & + \\
\hline Desulfovibrio desulfuricans & + & + \\
\hline termite gut homogenate clone $R s-N 31$ proteobacterium & + & + \\
\hline termite gut homogenate clone Rs-M89 proteobacterium & + & + \\
\hline uranium mining waste pile clone JG37-AG-139 proteobacterium & + & + \\
\hline forest soil clone $\mathrm{S1204}$ & + & + \\
\hline heavy metal-contaminated soil clone a13134 & + & + \\
\hline Polyangium cellulosum str. $87-5$ & + & + \\
\hline Polyangium cellulosum str. 9741 & - & + \\
\hline $\begin{array}{l}\text { soil sample uranium mining waste pile near town Johanngeorgenstadt clone } \\
\text { JG36-TzT-168 proteobacterium }\end{array}$ & + & + \\
\hline marine tidal mat clone BTM36 & + & - \\
\hline Nannocystis exedens str. Na e571 & + & + \\
\hline sludge clone A9 & + & + \\
\hline hydrothermal sediment clone AF420357 & + & + \\
\hline Enhygromyxa salina str. SHK-1 & + & - \\
\hline uranium mining waste pile clone JG37-AG-15 proteobacterium & + & + \\
\hline bacterioplankton clone ZA3704c & + & + \\
\hline uranium mining waste pile clone JG34-KF-243 proteobacterium & + & + \\
\hline bioreactor clone mle1-27 & + & + \\
\hline uranium mining waste pile clone JG34-KF-14 proteobacterium & + & + \\
\hline Desulfuromonas sp. clone AKS68 & + & + \\
\hline Cytophaga sp. str. Dex80-43 & + & + \\
\hline DCP-dechlorinating consortium clone SHA-72 & - & + \\
\hline uranium mining waste pile clone JG37-AG-33 proteobacterium & + & + \\
\hline marine sediment clone Boll1 & + & + \\
\hline Mono lake clone ML635J-58 & + & + \\
\hline Great Artesian Basin clone B83 & + & + \\
\hline Cytophaga sp. str. Dex80-64 & + & + \\
\hline deep marine sediment clone $M B-A 2-137$ & + & + \\
\hline Antarctic sediment clone LH5_30 & + & + \\
\hline uranium mill tailings soil sample clone GuBH2-AD/TzT-67 proteobacterium & + & + \\
\hline uranium mining waste pile clone JG37-AG-133 proteobacterium & + & + \\
\hline deep marine sediment clone $M B-B 2-106$ & + & + \\
\hline
\end{tabular}




\begin{tabular}{|c|c|c|}
\hline forested wetland clone RCP2-62 & + & + \\
\hline uranium mill tailings soil sample clone GuBH2-AG-114 proteobacterium & + & + \\
\hline acid mine drainage clone AS6 & + & + \\
\hline hydrothermal sediment clone AF420341 & + & + \\
\hline uranium mill tailings soil sample clone Sh765B-TzT-29 proteobacterium & + & + \\
\hline Great Artesian Basin clone G13 & + & + \\
\hline uranium mining waste pile clone JG37-AG-90 proteobacterium & + & + \\
\hline bacterioplankton clone ZA3735c & + & + \\
\hline Rocky Mountain alpine soil clone Sla-1H & + & + \\
\hline uranium mining waste pile clone JG37-AG-128 proteobacterium & + & + \\
\hline hydrothermal sediment clone AF420354 & + & + \\
\hline forested wetland clone FW140 & + & - \\
\hline forested wetland clone FW110 & + & + \\
\hline hydrothermal sediment clone AF420338 & + & + \\
\hline forest soil clone NOS7.157WL & + & + \\
\hline granular sludge clone Rlp32 & + & + \\
\hline granular sludge clone R3p4 & + & + \\
\hline Desulfacinum hydrothermale str. MT-96 & + & + \\
\hline DCP-dechlorinating consortium clone SHD-1 & + & + \\
\hline coal effluent wetland clone RCP185 & + & + \\
\hline forested wetland clone FW57 & + & + \\
\hline forested wetland clone FW13 & + & + \\
\hline TCE-contaminated site clone ccslm 247 & + & + \\
\hline epibiontic clone C11-D3 & + & + \\
\hline marine sediment above hydrate ridge clone Hyd24-11 proteobacterium & + & + \\
\hline inactive deep-sea hydrothermal vent chimneys clone IndB2-42 & + & + \\
\hline anoxic marine sediment clone LDI-PA38 & + & + \\
\hline Mono Lake at depth 23 m station 6 July 2000 clone ML623J-57 proteobacterium & + & + \\
\hline Cytophaga sp. str. BHI60-57B & + & + \\
\hline Psychrophilic sulfate-reducing isolate str. LSv23 bacterium & + & + \\
\hline marine sediment above hydrate ridge clone Hyd01-n proteobacterium & + & + \\
\hline Riftia pachyptila's tube clone R103-B13 & + & + \\
\hline gas hydrate clone Hyd89-51 & + & + \\
\hline uranium mining waste pile clone JG37-AG-30 proteobacterium & + & + \\
\hline DCP-dechlorinating consortium clone SHA-51 & + & + \\
\hline benzoate-degrading consortium clone BA044 & - & + \\
\hline Syntrophus buswellii str. DSM 2612 & - & + \\
\hline Syntrophus gentianae str. HQgoel & + & + \\
\hline forested wetland clone FW117 & + & + \\
\hline acid mine drainage clone BA18 & + & + \\
\hline marine sediment above hydrate ridge clone Hyd89-61 proteobacterium & + & - \\
\hline marine surface sediment clone $S B 2$ & + & + \\
\hline temperate estuarine mud clone KM62 & + & + \\
\hline Desulfobacterium cetonicum str. DSM 7267 oil recovery water & + & - \\
\hline sulfate-reducing habitat clone SLM-CP-116 & + & + \\
\hline sediment isolate str. EbS7 & - & + \\
\hline hydrothermal sediment clone AF420340 & + & + \\
\hline termite gut homogenate clone $R s-K 70$ proteobacterium & + & + \\
\hline
\end{tabular}




\begin{tabular}{|c|c|c|}
\hline marine methane seep clone 1427 & + & + \\
\hline Antarctic sediment clone SB1_49 & + & + \\
\hline Guaymas Basin hydrothermal vent sediments clone B01R011 & + & + \\
\hline Guaymas Basin hydrothermal vent sediments clone B01R004 & - & + \\
\hline Antarctic sediment clone SB2_56 & + & + \\
\hline Flexispira rappini $F H 9702248$ & + & + \\
\hline Helicobacter heilmannii str. MM2 & + & + \\
\hline Helicobacter aurati str. MIT 97-5075c & + & + \\
\hline Helicobacter cetorum str. MIT 99-5656 & + & + \\
\hline Helicobacter pylori str. 85008 & + & + \\
\hline Helicobacter suncus str. Kaz-2 & + & + \\
\hline Helicobacter felis str. Dog-1 & + & + \\
\hline Helicobacter heilmannii str. C4S & + & + \\
\hline Helicobacter pullorum str. NCTC 12826 & + & + \\
\hline Helicobacter rodentium str. MIT 96-1312 & + & + \\
\hline Helicobacter pylori str. ATCC $49396 T$ & + & + \\
\hline Helicobacter sp. blood isolate 964 & + & + \\
\hline Helicobacter rappini W.Tee-Bat & + & + \\
\hline Helicobacter winghamensis str. NLEP 97-1611 & + & + \\
\hline Helicobacter rappini W.Tee-Yu & + & + \\
\hline Helicobacter sp. 'liver 3' str. liver 3 & + & + \\
\hline hydrothermal vent clone $P V B \_10$ & - & + \\
\hline termite gut homogenate clone Rs-P71 proteobacterium & + & + \\
\hline Riftia pachyptila's tube clone R76-B51 & + & + \\
\hline hydrocarbon seep clone GCAO14 & - & + \\
\hline strain isolate str. Dex60-82 & - & + \\
\hline hydrothermal sediment clone AF420359 & - & + \\
\hline hydrothermal vent polychaete mисоиs clone P. palm C 84 & - & + \\
\hline S17sBac16 complete clone & + & + \\
\hline UASB reactor granular sludge clone $P D-U A S B-2$ proteobacterium & - & + \\
\hline $\begin{array}{l}\text { hydrothermal vent } 9 \text { degrees North East Rise Pacific Ocean clone } \\
\text { CH5_6_BAC_16SrRNA_9N_EPR }\end{array}$ & - & + \\
\hline termite gut homogenate clone $\mathrm{Rs}-\mathrm{H} 40$ proteobacterium & + & + \\
\hline strain isolate str. BHI80-49 & + & + \\
\hline Arcobacter cryaerophilus & + & + \\
\hline Sulfurospirillum deleyianum str. Spirillum 5175 & - & + \\
\hline Campylobacter sp. str. $N O 2 B$ & - & + \\
\hline temperate estuarine mud clone KM61 & + & + \\
\hline Campylobacter showae & + & - \\
\hline Campylobacter helveticus & + & + \\
\hline termite gut homogenate clone Rs-M59 proteobacterium & + & - \\
\hline penguin droppings sediments clone KD8-87 & + & + \\
\hline magnetic coccus $M P 17$ & + & - \\
\hline uranium mining waste pile near Johanngeorgenstadt soil clone JG37-AG-21 & + & + \\
\hline soil isolate Ellin301 & + & + \\
\hline lichen-dominated Antarctic cryptoendolithic community clone FBP483 & + & - \\
\hline termite gut homogenate clone Rs-J59 bacterium & - & + \\
\hline $\begin{array}{l}\text { ground water deep-well injection disposal site radioactive wastes Tomsk-7 clone } \\
\text { S15A-MN100 }\end{array}$ & + & + \\
\hline
\end{tabular}




\begin{tabular}{|c|c|c|}
\hline termite gut homogenate clone Rs-J10 bacterium & - & + \\
\hline Collinsella aerofaciens str. JCM7791 & + & - \\
\hline sponge clone TK39 & + & - \\
\hline bacterioplankton clone ZA3612c & + & + \\
\hline forested wetland clone RCPI-37 & + & + \\
\hline forested wetland clone RCP1-77 & - & + \\
\hline \multirow[t]{2}{*}{ forest soil clone DUNssu275 (-3A) (OTU\#188) } & + & + \\
\hline & + & + \\
\hline Mammoth cave clone CCM13a & + & + \\
\hline forested wetland clone RCP2-105 & + & + \\
\hline bacterioplankton clone AEGEAN_247 & + & + \\
\hline marine sediment clone $M B-A 2-100$ & + & + \\
\hline forested wetland clone RCP1-33 & + & - \\
\hline dilution (10e-7) brackish section Weser estuary isolate str. GP-5 GP-5 & - & + \\
\hline Sporichthya polymorpha str. IFO 12702 & - & + \\
\hline lichen-dominated Antarctic cryptoendolithic community clone FBP406 & + & + \\
\hline Frankia sp & - & + \\
\hline Frankia sp. Sn5-8 & + & + \\
\hline Sturt arid-zone soil clone \#0425-2M17 & + & + \\
\hline uranium mill tailings clone Gitt-KF-183 & + & + \\
\hline deep marine sediment clone $M B-A 2-108$ & + & + \\
\hline uranium mining waste pile clone JG34-KF-418 & + & + \\
\hline lichen-dominated Antarctic cryptoendolithic community clone FBP417 & - & + \\
\hline soil clone \#0319-7G21 & + & + \\
\hline Streptomyces galbus str. DSM40480 & + & + \\
\hline Streptomyces scabiei str. DNK-G01 & + & + \\
\hline Streptomyces cinnabarinus str. ISP 5467 & + & + \\
\hline Kitasatospora setae str. KM-6054 & + & + \\
\hline Streptacidiphilus carbonis str. JL 415; DSM 41754 & - & + \\
\hline Trichotomospora caesia str. IFO14562 & + & + \\
\hline Streptomyces subrutilus str. DSM 40445 & + & + \\
\hline soil clone $228-1$ & + & + \\
\hline Kitasatospora cystarginea str. IFO14836T & + & + \\
\hline soil clone $41-1$ & + & + \\
\hline Streptomyces setonii str. ATCC25497 & + & + \\
\hline Streptomyces bikiniensis str. DSM40581 & + & + \\
\hline uranium mining waste pile soil sample clone JG30-KF-A23 & + & + \\
\hline earthworm burrow isolate B33D1 & + & + \\
\hline DCP-dechlorinating consortium clone SHA-34 & + & + \\
\hline marine sediment clone Bol7 & + & + \\
\hline Streptomyces sampsonii str. ATCC25495 & + & + \\
\hline Streptomyces coelicolor & + & + \\
\hline Streptomyces coelicolor str. M145 ssp. A3(2) & + & + \\
\hline hypersaline lake clone ML602J-44 & + & + \\
\hline Streptomonospora salina str. YIM90002 & - & + \\
\hline Nocardiopsis listeri str. DSM 40297T & - & + \\
\hline Actinomadura pelletieri str. IMSNU $22169 T$ & + & - \\
\hline Actinomadura fulvescens str. DSM $43923 T$ & + & + \\
\hline
\end{tabular}




\begin{tabular}{|c|c|c|}
\hline Nonomuraea polychroma str. IFO 14345 & + & + \\
\hline Nonomuraea subsp. roseoviolacea str. SF 2303 & - & + \\
\hline Nonomuraea terrinata str. DSM 44505 & - & + \\
\hline Microbispora rosea subsp. aerata str. ATCC 27098 & + & + \\
\hline Rhodoglobus vestalii str. LV3 & + & + \\
\hline Leifsonia aquatica str. JCM1368 & - & + \\
\hline Firmicutes isolate str. $d 8$ & + & - \\
\hline termite gut homogenate clone Rs-F2O bacterium & - & + \\
\hline Microbacterium kitamiense CV88 & + & - \\
\hline Microbacterium lacticum & + & + \\
\hline glacial ice isolate str. SB12K-2-1 & + & + \\
\hline Microbacterium sp. str. VKM Ac-2048 & + & - \\
\hline Cryocola antiquus str. VKM 103PF & + & + \\
\hline Microbacterium resistens str. $2002-59119$ & + & + \\
\hline Microbacterium sp. str. IFO16060 & - & + \\
\hline Arctic sea ice ARK10165 & - & + \\
\hline Arctic sea ice ARK10173 & + & + \\
\hline freshwater isolate str. MWH-Ta3 & + & + \\
\hline freshwater clone SV1-16 & - & + \\
\hline Rathayibacter rathayi str. DSM 7485 & + & + \\
\hline Georgenia muralis str. $1 A-C$ & + & + \\
\hline penguin droppings sediments clone KD3-138 & + & + \\
\hline Cellulomonadaceae str. WB9 & + & + \\
\hline Cellulomonadaceae str. W6 & + & + \\
\hline Cellulomonadaceae str. WB13 & - & + \\
\hline Cellulomonas gelida str. DSM $20111 T$ & + & + \\
\hline Cellulosimicrobium cellulans str. NCIMB 11025 & + & + \\
\hline Jonesia quinghaiensis str. DSM 15701 & + & + \\
\hline Promicromonospora sukumoe str. DSM 44121 & + & + \\
\hline Beutenbergia cavernosa str. DSM 12333 & + & + \\
\hline Actinobacteria str. VeCb6 & + & + \\
\hline termite gut homogenate clone Rs-M95 bacterium & + & + \\
\hline Arthrobacter psychrolactophilus & + & + \\
\hline Arthrobacter oxydans str. DSM 20119 & + & + \\
\hline Arthrobacter globiformis & + & + \\
\hline Arthrobacter sp str. AC-51 & + & + \\
\hline Varibaculum cambriense str. CCUG 44998 & + & + \\
\hline Yania halotolerans str. YIM 70085 & + & + \\
\hline TCE-contaminated site clone ccspost 2208 & + & + \\
\hline glacial ice isolate str. CanDirtyl & + & + \\
\hline Arthrobacter agilis str. DSM 20550 & + & + \\
\hline termite gut homogenate clone Rs-N91 bacterium & + & + \\
\hline termite gut homogenate clone Rs-M66 bacterium & - & + \\
\hline Arthrobacter ureafaciens str. DSM 20126 & + & + \\
\hline Arthrobacter nicotianae str. SB42 & + & + \\
\hline Micrococcus luteus str. HN2-11 & + & + \\
\hline Kocuria roseus & + & + \\
\hline Kocuria rhizophila str. KL-057 & - & + \\
\hline
\end{tabular}




\begin{tabular}{|c|c|c|}
\hline Brevibacterium iodinum str. DSM $2062 T$ & + & + \\
\hline Brachybacterium sacelli str. LMG 20338 & - & + \\
\hline Brachybacterium conglomeratum str. NCIB 9859 & - & + \\
\hline Brachybacterium nesterenkovii str. DSM 9573 & + & + \\
\hline Actinomyces naeslundii & + & + \\
\hline Arcanobacterium haemolyticum str. CIP 103370 & - & + \\
\hline Bifidobacterium psychraerophilum str. T16 & + & + \\
\hline Bifidobacterium pseudocatenulatum str. JCM1200 & - & + \\
\hline Bifidobacterium adolescentis str. E-981074T & - & + \\
\hline Bifidobacterium thermacidophilum porcinum subsp. suis str. P3-14 subsp. & - & + \\
\hline Bifidobacteriaceae genomosp. $\mathrm{Cl}$ & - & + \\
\hline Bifidobacterium breve str. $K B 92$ & - & + \\
\hline Kineosporia aurantiaca str. JCM3230 & + & + \\
\hline lichen-dominated Antarctic cryptoendolithic community clone FBP402 & + & + \\
\hline endemic to Mojave Desert isolate str. AS3138 AS3138 & - & + \\
\hline Kineococcus aurantiacus str. IFO 15268 & + & + \\
\hline Aeromicrobium erythreum str. NRRL B-3381 & - & + \\
\hline Aeromicrobium marinum str. $T 2$ & - & + \\
\hline Nocardioides sp. str. V4.BO.15 = MM_2364 & + & + \\
\hline Actinoplanes utahensis str. IMSNU 20044T & + & + \\
\hline $\begin{array}{l}\text { related to BDA1-5 (Marine Gram-positive ) Actinomycetes clone OCS155 } \\
\text { OCS155 }\end{array}$ & + & + \\
\hline Actinoplanes roseosporangius str. IMSNU 22133 & + & + \\
\hline Actinoplanes capillaceus str. K95-5561 & + & + \\
\hline Actinoplanes garbadinensis str. IMSNU 20040 & + & + \\
\hline Actinoplanes derwentensis str. IFO $14935 T$ & + & + \\
\hline Actinoplanes tuftoflagellus str. IMSNU 22135 & + & + \\
\hline Actinoplanes utahensis str. ATCC 31044 & + & + \\
\hline Actinoplanes regularis str. IFO $12514 T$ & + & + \\
\hline Actinoplanes yunnanensis str. IFO $14459 T$ & + & + \\
\hline Couchioplanes subsp. caeruleus str. IFO13939 & + & + \\
\hline Couchioplanes subsp. caeruleus str. IFO13939 & + & + \\
\hline acid mine drainage clone ASL8 & + & + \\
\hline Actinoplanes durhamensis str. IMSNU $22124 T$ & + & + \\
\hline Micromonospora marina str. JSM3-1 & + & + \\
\hline Catellatospora subsp. citrea str. IMSNU $22008 T$ subsp. & - & + \\
\hline Amycolatopsis mediterranei str. NRRL B-3240 & + & + \\
\hline Amycolatopsis tolypomycina str. DSM 44544 & + & - \\
\hline Amycolatopsis mediterranei str. IMSNU 20056T & + & - \\
\hline Amycolatopsis sulphurea str. IMSNU $20060 T$ & + & + \\
\hline Amycolatopsis vancoresmycina str. DSM 44592 & + & - \\
\hline Saccharomonospora azurea str. M.Goodfel K161=NA128 (type st & + & + \\
\hline Mycobacterium cf.xenopi 'Hymi_Wue Tb_939/99' str. Hymi_Wue Tb_939/99 & + & + \\
\hline Mycobacterium palustre str. E846 & + & + \\
\hline Mycobacterium aichiense str. JS618 & + & + \\
\hline Mycobacterium sp. 3 & + & + \\
\hline Mycobacterium ratisbonense str. SD4 & - & + \\
\hline Mycobacterium holsaticum str. 1406 & + & + \\
\hline Mycobacterium pyrenivorans str. DSM 44605 & + & + \\
\hline
\end{tabular}




\begin{tabular}{|c|c|c|}
\hline USA: Colorado Fort collins Horsetooth Reservoir clone HTDD3 & + & + \\
\hline Mycobacterium chelonae str. CIP $104535 T$ & + & + \\
\hline Mycobacterium cf. triplex 'isolate 23 ' 23 & + & + \\
\hline Mycobacterium tuberculosis str. NCTC $7416 \mathrm{H} 37 \mathrm{Rv}$ & + & + \\
\hline Mycobacterium sp. str. $1 B(C D)$ & + & + \\
\hline Mycobacterium terrae str. ATCC 15755 & + & + \\
\hline Mycobacterium rhodesiae str. JS60 & + & + \\
\hline Mycobacterium marinum & + & + \\
\hline Mycobacterium neoaurum str. ATCC 25795 & + & + \\
\hline Mycobacterium brisbanense str. W6743; ATCC 49938 & - & + \\
\hline Mycobacterium chlorophenolicum str. PCP-I & + & + \\
\hline Gordona terrae & + & + \\
\hline Gordonia alkanivorans & + & + \\
\hline Gordonia amarae str. DSM43392 & - & + \\
\hline Gordonia polyisoprenivorans str. $Y 2 \mathrm{~K}$ & + & + \\
\hline Dietzia maris & - & + \\
\hline Corynebacterium xerosis str. DSM 20743 & + & + \\
\hline Corynebacterium tuscaniae str. ISS-5309 & + & + \\
\hline Corynebacterium jeikeium str. ATCC 43734 & + & + \\
\hline $\begin{array}{l}\text { Corynebacterium mucifaciens National Microbiology Laboratory Special } \\
\text { identifier 01-0118 }\end{array}$ & + & + \\
\hline $\begin{array}{l}\text { Corynebacterium simulans National Microbiology Laboratory Special identifier } \\
00-0186\end{array}$ & + & + \\
\hline Corynebacterium spheniscorum str. CCUG 45512 & + & + \\
\hline polluted aquifer clone BVC83 & + & + \\
\hline Rhodococcus ruber str. DSM43338 & + & + \\
\hline forested wetland clone RCP2-103 & + & + \\
\hline Rhodococcus opacus str. B-4 & + & + \\
\hline Rhodococcus corynebacterioides str. DSM 20151 & - & + \\
\hline Rhodococcus species & - & + \\
\hline Dietzia sp. str. E9_2 & - & + \\
\hline Nocardia otitidiscaviarum str. S639 & + & + \\
\hline Nocardia caishijiensis str. F829 & - & + \\
\hline Nocardia sp. str. 99-08-244A & - & + \\
\hline Nocardia veterana str. DSM 44445 & - & + \\
\hline Nocardia yamanashiensis str. IFM 0265 & + & + \\
\hline Nocardia cyriacigeorgica str. D1627T & - & + \\
\hline Nocardia pseudovaccinii str. DSM 43406 & + & + \\
\hline Nocardia transvalensis str. DSM 43405 & + & + \\
\hline Nocardia otitidiscaviarum str. DSM43242 & + & + \\
\hline Nocardia uniformis str. DSM 43136 & + & + \\
\hline Desulfotomaculum thermobenzoicum str. DSM 6193 & + & + \\
\hline UASB granular sludge clone $J P$ & + & + \\
\hline G+C Gram-positive clone YNPRH70A & + & + \\
\hline Desulfotomaculum thermoacetoxidans str. DSM 5813 & + & + \\
\hline Natronoanaerobium aggerbacterium G-M16NWC-4 & - & + \\
\hline Desulfotomaculum solfataricum str. V21 & + & + \\
\hline UASB granular sludge clone UT-2 & - & + \\
\hline saltmarsh clone $L C P-89$ & + & + \\
\hline
\end{tabular}




\begin{tabular}{|c|c|c|}
\hline granular sludge clone $R 4 b 14$ & + & + \\
\hline trichloroethene-contaminated site clone FTLM142 bacterium & + & + \\
\hline uranium mining waste pile soil clone $J G 30-K F-C 12$ & + & + \\
\hline Guaymas Basin hydrothermal vent sediments clone B03R012 & + & - \\
\hline deep marine sediment clone $\mathrm{MB}-\mathrm{C} 2-106$ & - & + \\
\hline Mono Lake at depth $23 \mathrm{~m}$ station 6 July 2000 clone ML623J-19 & + & + \\
\hline Guaymas Basin hydrothermal vent sediments clone B01R005 & + & - \\
\hline deep marine sediment clone $M B-B 2-103$ & + & - \\
\hline anoxic marine sediment clone LDI-PA39 & + & + \\
\hline anaerobic sludge isolate str. JE & + & + \\
\hline Thermaerobacter marianensis & + & + \\
\hline Thermaerobacter nagasakiensis str. JCM 11223 & + & + \\
\hline TCE-contaminated site clone FTL22 & + & + \\
\hline sponge symbiont clone TK19 & + & + \\
\hline uranium mill tailings soil clone Sh765B-TzT/AG-5 & + & + \\
\hline uranium mill tailings soil sample clone Sh765B-TzT-20 bacterium & + & + \\
\hline deep marine sediment clone $M B-B 2-113$ & + & + \\
\hline Dehalococcoides ethenogenes str. strain 195 & + & + \\
\hline deep marine sediment clone $M B-C 2-127$ & + & + \\
\hline deep marine sediment clone $M B-A 2-110$ & + & + \\
\hline deep marine sediment clone $M B-A 2-103$ & + & - \\
\hline uranium mill tailings soil sample clone Sh765B-TzT-6 bacterium & + & + \\
\hline forested wetland clone FW60 & + & + \\
\hline sponge clone TK10 & + & + \\
\hline penguin droppings sediments clone KD4-96 & + & - \\
\hline forest soil clone C083 & + & + \\
\hline trichloroethene-contaminated site clone FTL276 bacterium & + & + \\
\hline forest soil clone S085 & + & + \\
\hline hydrothermal vent clone VC2.1Bac 23 & + & - \\
\hline Thermovibrio ammoniificans str. $H B-1$ & + & + \\
\hline Selenomonas ruminantium str.JCM6582 & + & + \\
\hline Anaerovibrio lipolyticus str. ATCC 33276 & - & + \\
\hline Selenomonas ruminantium str. $S 20$ & + & + \\
\hline Centipeda periodontii str. $H B-2$ & + & + \\
\hline pig feces clone & + & + \\
\hline Dialister invisus str. E7_25 & + & + \\
\hline Great Artesian Basin clone G07 & + & + \\
\hline DCP-dechlorinating consortium clone SHA-109 & + & + \\
\hline chlorobenzene-degrading consortium clone IIA-26 & + & + \\
\hline thermal soil clone YNPFFP9 & + & + \\
\hline anoxic bulk soil flooded rice microcosm clone BSV43 clone & + & + \\
\hline termite gut homogenate clone Rs-J36 bacterium & - & + \\
\hline$M C B$-contaminated groundwater-treating reactor clone $R B 9 C 2$ & - & + \\
\hline termite gut homogenate clone Rs-P50 bacterium & + & + \\
\hline Desulfosporosinus orientis str. DSMZ 7493 & + & - \\
\hline deep marine sediment clone $\mathrm{MB}-\mathrm{C} 2-152$ & + & + \\
\hline termite gut homogenate clone Rs-A28 bacterium & + & + \\
\hline drinking water system simulator clone $\mathrm{HOClCi} 9$ & - & + \\
\hline
\end{tabular}




\begin{tabular}{|c|c|c|}
\hline benzene-contaminated groundwater clone ZZ12C8 & + & + \\
\hline forested wetland clone RCP2-71 & + & + \\
\hline UASB granular sludge clone UT-1 & - & + \\
\hline termite gut homogenate clone Rs-B88 bacterium & + & - \\
\hline swine intestine clone p-3075-SwA5 & + & + \\
\hline swine intestine clone p-2876-6C5 & + & + \\
\hline rumen clone $6 C 3 d-11$ & + & + \\
\hline termite gut homogenate clone Rs-F27 bacterium & + & + \\
\hline termite gut homogenate clone Rs-G40 bacterium & + & + \\
\hline termite gut homogenate clone Rs-D48 bacterium & + & + \\
\hline Clostridium nexile & + & + \\
\hline anaerobic digester clone AAO2 & - & + \\
\hline human stool clone B065 & + & + \\
\hline termite gut clone Rs-L15 & + & + \\
\hline human colonic clone $\mathrm{HuCA2O}$ & + & + \\
\hline oxidoreducens str. G2-2 & - & + \\
\hline swine intestine clone p-1594-c5 & + & + \\
\hline Lachnospira pectinoschiza & + & + \\
\hline ruminantium str. GA195 & + & - \\
\hline TCE-dechlorinating microbial community clone $4 C$ & - & + \\
\hline termite gut homogenate clone Rs-G77 bacterium & + & + \\
\hline termite gut homogenate clone Rs-B14 bacterium & + & + \\
\hline termite gut homogenate clone Rs-N53 & + & + \\
\hline termite gut homogenate clone $R s$-K41 bacterium & + & + \\
\hline termite gut homogenate clone Rs-F76 bacterium & + & + \\
\hline termite gut homogenate clone Rs-N71 bacterium & + & + \\
\hline DCP-dechlorinating consortium clone SHA-58 & + & + \\
\hline termite gut homogenate clone BCf9-13 & + & + \\
\hline oral periodontitis clone $\mathrm{FX} 028$ & + & + \\
\hline termite gut homogenate clone Rs-N27 bacterium & + & + \\
\hline termite gut homogenate clone Rs-E61 bacterium & + & + \\
\hline termite gut homogenate clone Rs-N82 bacterium & + & + \\
\hline termite gut homogenate clone Rs-F43 bacterium & + & + \\
\hline Evry municipal wastewater treatment plant clone $012 C 11 \_B \_S D \_P 15$ & + & + \\
\hline termite gut homogenate clone Rs-Q64 bacterium & + & + \\
\hline chlorobenzene-degrading consortium clone IA-19 & + & + \\
\hline oral clone $P 2 P B \_46 P 3$ & - & + \\
\hline oral periodontitis clone $\mathrm{FX} 033$ & - & + \\
\hline Clostridium caminithermale str. DVird3 & + & + \\
\hline coal effluent wetland clone RCP216 & + & + \\
\hline Great Artesian Basin clone R82 & - & + \\
\hline human subgingival plaque clone BB142 & + & - \\
\hline Tepidibacter thalassicus str. SC 562 & + & + \\
\hline Clostridium paradoxum str. DSM $7308 T$ & - & + \\
\hline Clostridium paradoxum str. DSM $7308 T$ & - & + \\
\hline midgut homogenate Pachnoda ephippiata larva clone PeM47 & + & + \\
\hline Isolation and identification hyper-ammonia producing swine storage pits manure & + & + \\
\hline termite gut homogenate clone Rs-H81 bacterium & + & + \\
\hline
\end{tabular}




\begin{tabular}{|c|c|c|}
\hline Sedimentibacter sp. str. BRS2 & + & - \\
\hline oral periodontitis clone EX153 & + & + \\
\hline Peptostreptococcaceae bacterium 19 gly3 & - & + \\
\hline TCE-dechlorinating microbial community clone $1 G$ & + & + \\
\hline Finegoldia magna str. ATCC 29328 & + & + \\
\hline Peptostreptococcus sp. str. E3_32 & + & + \\
\hline Finegoldia magna & + & + \\
\hline Peptostreptococcus sp. oral clone P4PA_156 P4 oral & + & + \\
\hline Peptoniphilus lacrimalis str. CCUG 31350 & - & + \\
\hline Anaerococcus vaginalis str. CCUG 31349 & + & + \\
\hline geothermal site isolate str. G1 & + & + \\
\hline Bacillus schlegelii str. ATCC $43741 T$ & + & + \\
\hline Paenibacillus nematophilus str. NEMIb & + & + \\
\hline Paenibacillus turicensis str. MOL722 & + & + \\
\hline Paenibacillus borealis $K K 20$ & + & + \\
\hline Paenibacillus sp. str. MB 2039 & + & + \\
\hline Paenibacillus thiaminolyticus str. DSM 7262 & - & + \\
\hline Bacillus sp. clone ML1228J-1 & + & + \\
\hline Brevibacillus borstelensis str. LMG 15536 & + & + \\
\hline Brevibacillus sp. MN $47.2 a$ & + & - \\
\hline Laceyella sacchari str. KCTC 9789 () & - & + \\
\hline Bacillus sp. clone ML615J-19 & + & + \\
\hline Bacillus algicola str. KMM 3737 & + & + \\
\hline uranium mill tailings clone Gitt-KF-76 & + & + \\
\hline Bacillus clausii str. GMBAE 42 & + & + \\
\hline Bacillus sp. str. 2216.25.2 & + & + \\
\hline Bacillus sp. str. SAFN-006 & + & + \\
\hline Bacillus baekryungensis str. SW-93 & + & + \\
\hline Lake Elmenteita isolate WE4 & - & + \\
\hline Bacillus vulcani str. $3 S-1$ & + & + \\
\hline Geobacillus thermocatenulatus str. DSM 730 & + & + \\
\hline Bacillus thermoleovorans & + & + \\
\hline Thermoactinomyces sp. str. 700375 & + & + \\
\hline Geobacillus jurassicus str. DS1 & + & + \\
\hline Geobacillus caldoxylosilyticus str. BGSC W98Al & - & - \\
\hline Geobacillus thermoleovorans str. B23 & + & + \\
\hline Geobacillus stearothermophilus & + & + \\
\hline Geobacillus stearothermophilus str. 46 & + & + \\
\hline Geobacillus stearothermophilus str. T10 & + & + \\
\hline Geobacillus thermodenitrificans str. DSM 466 & + & + \\
\hline Bacillus caldotenax str. DSM 406 & + & + \\
\hline Geobacillus sp. str. YMTC1049 & + & + \\
\hline Bacillus acidogenesis str. 105-2 & + & + \\
\hline Halobacillus yeomjeoni str. MSS-402 & + & + \\
\hline Salibacillus sp. str. YIM-kknyl6 & + & + \\
\hline Bacillus niacini str. IFO15566 & + & + \\
\hline Bacillus siralis str. 171544 & + & + \\
\hline Bacillus senegalensis str. RS8; CIP 106669 & + & + \\
\hline
\end{tabular}




\begin{tabular}{|c|c|c|}
\hline anoxic bulk soil flooded rice microcosm clone BSV45 clone & + & - \\
\hline anoxic bulk soil flooded rice microcosm clone BSV46 clone & + & + \\
\hline Bacillus firmus str. NCIMB 9366 & + & + \\
\hline Bacillus litoralis str. SW-211 & + & - \\
\hline Bacillus simplex str. DSM 1321T & + & - \\
\hline Bacillus megaterium str. QM B1551 & + & + \\
\hline Bacillus sp. str. KL-152 & + & - \\
\hline Bacillus pumilus str. S9 & - & + \\
\hline Pseudobacillus carolinae & + & + \\
\hline Bacillus licheniformis str. SAFN-031 & + & + \\
\hline Bacillus subtilis str. IAM $12118 T$ & + & + \\
\hline Bacillus sp. str. TGS750 & + & + \\
\hline Bacillus licheniformis str. SK-1 & + & + \\
\hline Bacillus mojavensis str. $M-1$ & + & + \\
\hline Bacillus sonorensis str. NRRL B-23155 & + & + \\
\hline Bacillus licheniformis str. Mol & + & + \\
\hline Bacillus licheniformis str. KL-068 & + & + \\
\hline Bacillus licheniformis str. DSM 13 & + & + \\
\hline Bacillus subtilis subsp. Marburg str. 168 & + & + \\
\hline Bacillus subtilis & + & + \\
\hline Staphylococcus auricularis str. MAFF911484 ATCC33753T & - & - \\
\hline Staphylococcus sp str. AG-30 & + & + \\
\hline Bacillus luciferensis str. LMG 18422 & + & + \\
\hline Bacillus sphaericus & + & + \\
\hline Caryophanon latum str. DSM 14151 & + & + \\
\hline Bacillus silvestris str. SAFN-O10 & - & + \\
\hline garbage compost isolate str. M32 & - & + \\
\hline Sporosarcina macmurdoensis str. CMS $21 \mathrm{w}$ & + & + \\
\hline Planococcus maritimus str. TF-9 & + & + \\
\hline Bacillus psychrodurans str. DSM $1171368 E 3$ & + & + \\
\hline compost clone $4-28$ & + & + \\
\hline feedlot manure clone $B 87$ & + & + \\
\hline Lactobacillus kitasatonis str. KM9212 & - & + \\
\hline Lactobacillus suntoryeus str. $L H$ & - & + \\
\hline Lactobacillus reuteri str. DSM 20016 T & - & + \\
\hline Lactobacillus frumenti str. TMW 1.666 & + & + \\
\hline Lactobacillus pontis str. LTH 2587 & + & + \\
\hline Pediococcus inopinatus str. DSM 20285 & - & + \\
\hline Pediococcus pentosaceus & - & + \\
\hline Lactobacillus letivazi str. JCL3994 & - & + \\
\hline Lactobacillus subsp. aviarius & + & + \\
\hline Lactobacillus perolens str. L532 & + & + \\
\hline cf. Alkalibacterium sp. isolate str. F1 & + & + \\
\hline Carnobacterium alterfunditum & - & + \\
\hline Enterococcus mundtii str. LMG 10748 & + & + \\
\hline Enterococcus saccharolyticus str. LMG 11427 & + & + \\
\hline Tetragenococcus muriaticus & + & + \\
\hline Enterococcus solitarius str. DSM 5634 & + & + \\
\hline
\end{tabular}




\begin{tabular}{|c|c|c|}
\hline Enterococcus cecorum str. ATCC43198 & + & + \\
\hline Enterococcus dispar str. LMG 13521 & + & + \\
\hline Lactococcus Il1403 subsp. lactis str. IL1403 & + & + \\
\hline Streptococcus equi subsp. zooepidemicus str. Tokyo1291 subsp. & + & + \\
\hline Streptococcus thermophilus str. DSM 20617 & + & + \\
\hline Streptococcus constellatus str. ATCC27823 & + & + \\
\hline Streptococcus suis str. 8074 & + & + \\
\hline Streptococcus cristatus str. ATCC 51100 & + & + \\
\hline Streptococcus mitis str. Sm91 & - & + \\
\hline Streptococcus gordonii str. ATCC 10558 & + & + \\
\hline Weeping tea tree witches'-broom phytoplasma tree & + & - \\
\hline Ash witches'-broom phytoplasma str. AshWB & - & + \\
\hline Chinaberry yellows phytoplasma str. CbY1 & - & + \\
\hline Australia isolate str. BVGY & - & - \\
\hline Eubacterium cylindroides & + & + \\
\hline Streptococcus pleomorphus & + & + \\
\hline TCE-contaminated site clone ccslm 238 & + & + \\
\hline phototrophic sludge clone PSB-M-3 & + & + \\
\hline Mycoplasma gypsbengalensis str. Gb-V33 & + & + \\
\hline Mycoplasma zalophus str. 4296C & - & + \\
\hline$M C B$-contaminated groundwater-treating reactor clone $R A 9 C 1$ & + & + \\
\hline Clostridiales oral clone P4PB_122 P3 & + & + \\
\hline forested wetland clone FW105 & + & - \\
\hline granular sludge clone R1p16 & + & + \\
\hline termite gut clone Rs-LO2 & + & + \\
\hline termite gut clone Rs-060 & + & + \\
\hline termite gut clone Rs-056 & + & + \\
\hline oral endodontic infection clone MCE3_9 & + & + \\
\hline Mono Lake at depth $35 \mathrm{~m}$ station $6 \mathrm{July} 2000$ clone ML635J-65 G+C & + & + \\
\hline termite gut homogenate clone Rs-J39 bacterium & + & + \\
\hline termite gut homogenate clone Rs-N85 bacterium & + & + \\
\hline termite gut homogenate clone Rs-H83 bacterium & + & + \\
\hline Mono Lake at depth $35 \mathrm{~m}$ station $6 \mathrm{July} 2000$ clone ML635J-14 G+C & - & + \\
\hline Clostridium papyrosolvens str. DSM 2782 & + & + \\
\hline Clostridium sp. str. JC3 & + & + \\
\hline Mono Lake at depth $35 \mathrm{~m}$ station $6 \mathrm{July} 2000$ clone ML635J-21 G+C & + & + \\
\hline termite gut clone $R s-068$ & + & + \\
\hline termite gut homogenate clone Rs-K92 bacterium & - & + \\
\hline termite gut homogenate clone Rs-A15 bacterium & + & + \\
\hline ckncm322-B3-7 clone & + & + \\
\hline termite gut homogenate clone Rs-M23 bacterium & + & + \\
\hline termite gut clone Rs-061 & + & + \\
\hline termite gut clone Rs-116 & + & + \\
\hline termite gut homogenate clone Rs-G04 bacterium & + & + \\
\hline termite gut homogenate clone Rs-M86 bacterium & + & - \\
\hline termite gut clone Rs-114 & + & + \\
\hline termite gut homogenate clone Rs-M34 bacterium & + & + \\
\hline termite gut homogenate clone Rs-M14 bacterium & + & + \\
\hline
\end{tabular}




\begin{tabular}{|c|c|c|}
\hline granular sludge clone $U A S B \_b r e w \_B 86$ & + & + \\
\hline termite gut homogenate clone $R s-Q 01$ bacterium & + & + \\
\hline human mouth clone P4PA_66 & + & + \\
\hline termite gut homogenate clone Rs-N94 bacterium & + & + \\
\hline termite gut homogenate clone Rs-C76 bacterium & + & - \\
\hline Oscillospira guilliermondii & - & + \\
\hline granular sludge clone $U A S B \_b r e w \_B 84$ & + & + \\
\hline termite gut homogenate clone Rs-N86 bacterium & + & + \\
\hline Lachnospiraceae bacterium 19gly4 & - & + \\
\hline termite gut homogenate clone Rs-C69 bacterium & + & + \\
\hline termite gut homogenate clone Rs-N73 bacterium & + & + \\
\hline ckncm301-B3-28 clone & + & + \\
\hline termite gut homogenate clone Rs-K32 bacterium & + & - \\
\hline termite gut homogenate clone Rs-H18 bacterium & + & - \\
\hline termite gut homogenate clone Rs-K11 bacterium & + & + \\
\hline termite gut clone Rs-109 & + & + \\
\hline termite gut clone Rs-058 & + & + \\
\hline termite gut homogenate clone Rs-NO2 bacterium & + & + \\
\hline termite gut homogenate clone Rs-N21 bacterium & + & + \\
\hline termite gut homogenate clone Rs-Q53 bacterium & + & + \\
\hline ckncm314-B7-17 clone & + & + \\
\hline granular sludge clone $U A S B \_b r e w \_B 25$ & + & + \\
\hline termite gut homogenate clone Rs-B34 bacterium & + & + \\
\hline termite gut clone Rs-093 & + & + \\
\hline termite gut homogenate clone Rs-N06 bacterium & + & + \\
\hline ckncm297-B1-1 clone & + & + \\
\hline termite gut homogenate clone Rs-M18 bacterium & + & + \\
\hline termite gut homogenate clone Rs-Q69 bacterium & - & + \\
\hline swine intestine clone p-2657-65A5 & - & + \\
\hline human colonic clone $\mathrm{HuCB5}$ & + & + \\
\hline Faecalibacterium prausnitzii str. ATCC 27766 & + & + \\
\hline rumen clone $3 \mathrm{COd}-3$ & + & + \\
\hline termite gut homogenate clone Rs-A13 bacterium & + & + \\
\hline UASB reactor granular sludge clone $P D-U A S B-4$ bacterium & + & + \\
\hline termite gut homogenate clone $R s-K 21$ bacterium & + & + \\
\hline TCE-contaminated site clone ccslm 210 & + & + \\
\hline Clostridium tyrobutyricum str. NIZO 51 & + & + \\
\hline Clostridium tyrobutyricum & + & + \\
\hline Clostridiaceae str. A4d & + & + \\
\hline rumen clone F23-C12 & + & + \\
\hline termite gut homogenate clone $R s$-Q18 bacterium & + & + \\
\hline Clostridium subterminale str. NCIMB 10746 & - & + \\
\hline Clostridium acetobutylicum str. ATCC $824(T)$ & + & + \\
\hline Clostridium acetobutylicum str. ATCC 824 & - & + \\
\hline Clostridium butyricum str. ATCC43755 & + & + \\
\hline
\end{tabular}


An OTU was considered present in the sample when $90 \%$ or more of its assigned probe pairs for its corresponding probe set were positive (positive fraction of $>0.90$ ). 